\section{Pacific Northwest}

National Laboratory

Operated by Battelle for the

U.S. Department of Energy

\title{
Geology of the Waste Treatment Plant Seismic Boreholes
}
D. B. Barnett
B. N. Bjornstad
K. R. Fecht
D. C. Lanigan
S. P. Reidel
C. F. Rust

May 2007

Prepared for U.S. Department of Energy under Contract DE-AC05-76RL01830 


\title{
DISCLAIMER
}

This report was prepared as an account of work sponsored by an agency of the United States Government. Neither the United States Government nor any agency thereof, nor Battelle Memorial Institute, nor any of their employees, makes any warranty, express or implied, or assumes any legal liability or responsibility for the accuracy, completeness, or usefulness of any information, apparatus, product, or process disclosed, or represents that its use would not infringe privately owned rights. Reference herein to any specific commercial product, process, or service by trade name, trademark, manufacturer, or otherwise does not necessarily constitute or imply its endorsement, recommendation, or favoring by the United States Government or any agency thereof, or Battelle Memorial Institute. The views and opinions of authors expressed herein do not necessarily state or reflect those of the United States Government or any agency thereof.

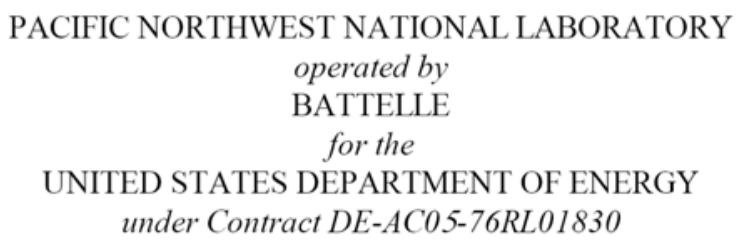

Printed in the United States of America

Available to DOE and DOE contractors from the Office of Scientific and Technical Information,

P.O. Box 62, Oak Ridge, TN 37831-0062;

ph: (865) 576-8401

fax: $(865) 576-5728$

email: reports@adonis.osti.gov

\begin{abstract}
Available to the public from the National Technical Information Service, U.S. Department of Commerce, 5285 Port Royal Rd., Springfield, VA 22161 ph: (800) 553-6847 fax: (703) 605-6900 email: orders@ntis.fedworld.gov

online ordering: http://www.ntis.gov/ordering.htm
\end{abstract}

This document was printed on recycled paper. 


\section{Geology of the Waste Treatment Plant Seismic Boreholes}
D. B. Barnett
B. N. Bjornstad
K. R. Fecht ${ }^{(a)}$
D. C. Lanigan
S. P. Reidel
C. F. Rust ${ }^{(b)}$

May 2007

Prepared for

the U.S. Department of Energy

under Contract DE-AC05-76RL01830

Pacific Northwest National Laboratory

Richland, Washington 99352
(a) Washington Closure Hanford, Richland, Washington
(b) Freestone Environmental Services, Inc., Richland, Washington 


\begin{abstract}
In 2006, the U.S. Department of Energy initiated the Seismic Boreholes Project (SBP) to emplace boreholes at the Waste Treatment Plant (WTP) site in order to obtain direct shear wave velocity (Vs) measurements and other physical property measurements in Columbia River basalt and interbedded sediments of the Ellensburg Formation. The goal was to reduce the uncertainty in the response spectra and seismic design basis, and potentially recover design margin for the WTP.

The characterization effort within the deep boreholes included 1) downhole measurements of the velocity properties of the suprabasalt, basalt, and sedimentary interbed sequences, 2) downhole measurements of the density of the subsurface basalt and sediments, and 3) geologic studies to confirm the geometry of the contact between the various basalt and interbedded sediments through examination of retrieved core from the core hole and data collected through geophysical logging of each borehole.

This report describes the results of the geologic studies from three mud-rotary boreholes and one cored borehole at the WTP. All four boreholes penetrated the entire Saddle Mountains Basalt and the upper part of the Wanapum Basalt where thick sedimentary interbeds occur between the lava flows. The basalt flows penetrated in Saddle Mountains Basalt included the Umatilla Member, Esquatzel Member, Pomona Member, and the Elephant Mountain Member. The underlying Priest Rapids Member of the Wanapum Basalt also was penetrated. The Ellensburg Formation sediments consist of the Mabton Interbed, the Cold Creek Interbed, the Selah Interbed, and the Rattlesnake Ridge Interbed; the Byron Interbed occurs between two flows of the Priest Rapids Member. The Mabton Interbed marks the contact between the Wanapum and Saddle Mountains Basalts.

The thicknesses of the basalts and interbedded sediments were within expected limits. However, a small reverse fault was found in the Pomona Member flow top. This fault has three periods of movement and less than $15 \mathrm{ft}$ of repeated section. Most of the movement on the fault appears to have occurred before the youngest lava flow, the 10.5-million-year-old Elephant Mountain Member, was emplaced above the Pomona Member.
\end{abstract}




\section{Contents}

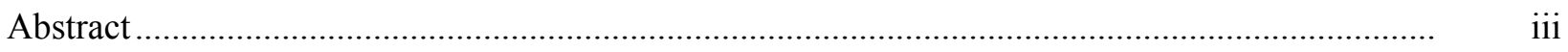

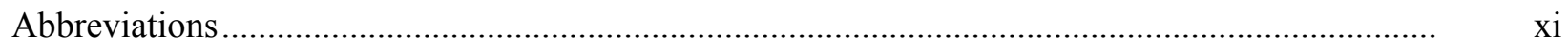

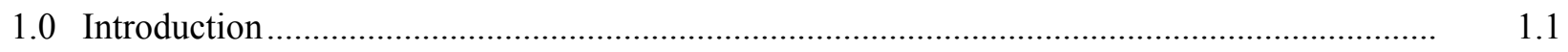

1.1 Waste Treatment Plant and the Seismic Boreholes Project............................................ 1.1

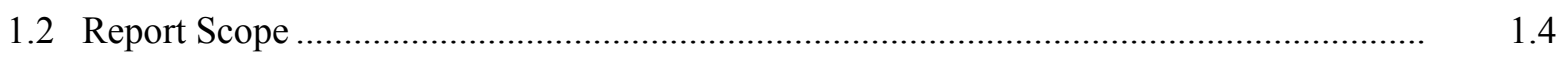

2.0 Stratigraphic Framework of the Pasco Basin and Hanford Site ........................................... 2.1

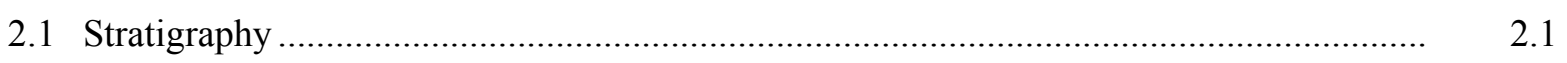

2.1.1 Columbia River Basalt Group............................................................................ 2.2

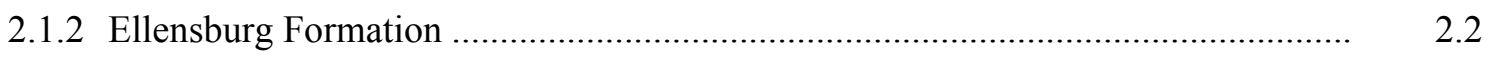

2.1.3 Post-Columbia River Basalt Group Sediments ................................................... 2.7

2.2 Nomenclature and Features of Lava Flows ................................................................ 2.8

2.2.1 Internal Basalt Flow Features ....................................................................... 2.8

2.3 Identification of Columbia River Basalt Group Lava Flows......................................... $\quad 2.10$

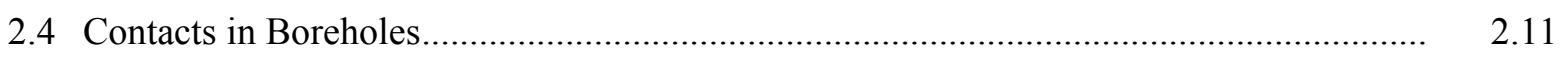

2.4.1 Geologists' and Drillers' Logs .................................................................... 2.11

2.4.2 Geophysical Logs ............................................................................... 2.11

3.0 Suprabasalt Sediments from Entry Boreholes at the Waste Treatment Plant ........................ 3.1

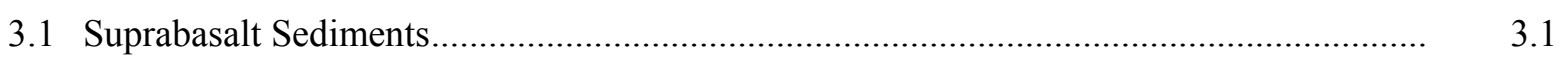

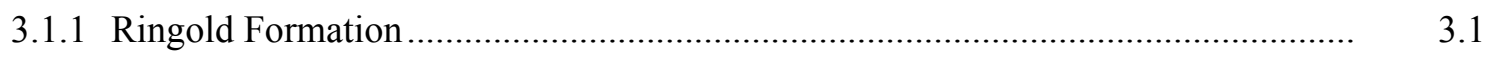

3.1.2 Cold Creek Unit ....................................................................................

3.1.3 Hanford Formation .................................................................................. 3.8

3.1.4 Recent Deposits ......................................................................................... 3.12

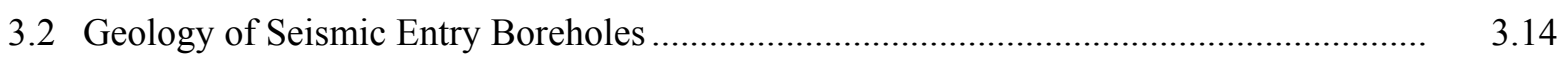

3.2.1 Entry Borehole C4998 - Geologic Interpretation ................................................ 3.14

3.2.2 Entry Borehole C4996 - Geologic Interpretation ............................................... 3.14

3.2.3 Entry Borehole C4997 - Geologic Interpretation ............................................ 3.17

3.2.4 Entry Borehole C4993 - Geologic Interpretation ............................................ 3.17

4.0 Columbia River Basalt at the Waste Treatment Plant .......................................................

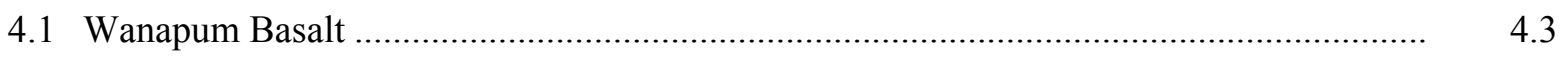

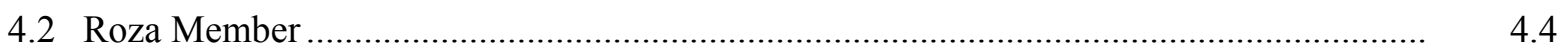

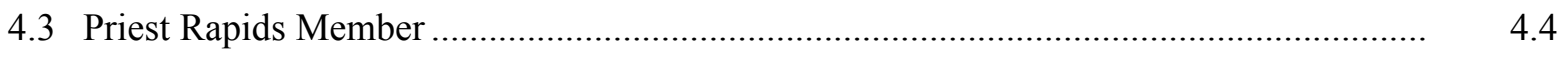

4.4 Saddle Mountains Basalt .................................................................................................

4.4.1 Umatilla Member .................................................................................. 4.5 
4.4.2 Esquatzel Member ........................................................................................ 4.6

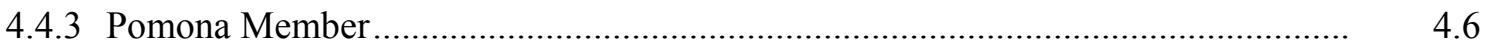

4.4.4 Elephant Mountain Member ........................................................................ 4.7

5.0 Ellensburg Sedimentary Deposits in and Around the Waste Treatment Plant Site.................. 5.1

5.1 Ellensburg Formation in the Vicinity of the Waste Treatment Plant Site ........................ 5.1

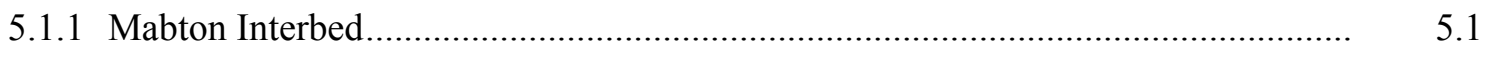

5.1.2 Cold Creek Interbed ................................................................................... 5.1

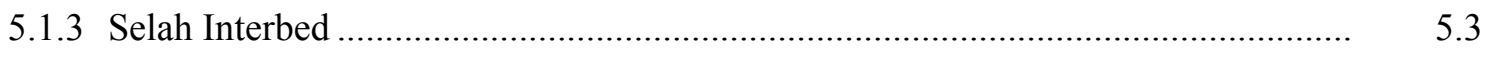

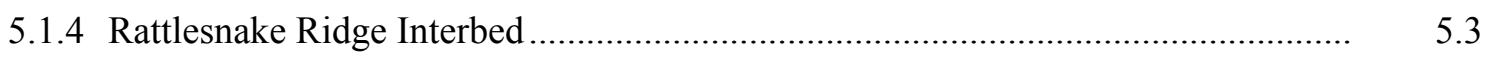

5.2 Ellensburg Formation Sedimentary Interbeds at the Waste Treatment Plant.................... 5.7

5.2.1 Mabton Interbed ............................................................................................ 5.7

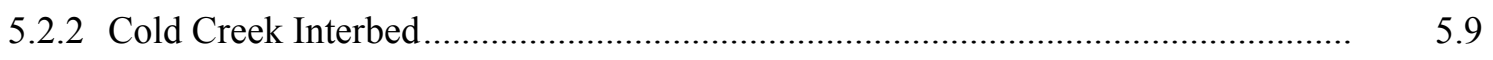

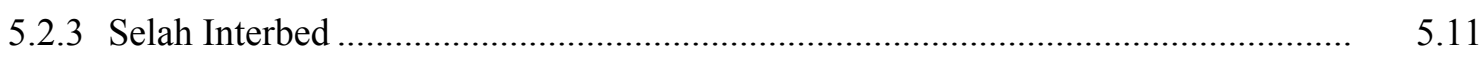

5.2.4 Rattlesnake Ridge Interbed ..................................................................... 5.12

6.0 Structural Geology at the Waste Treatment Plant Site......................................................

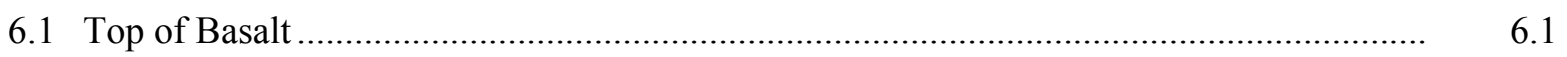

6.2 Fault in Brecciated Flow Top of Pomona Member at the Waste Treatment Plant............ $\quad 6.7$

6.2.1 Offsets in Fractures .......................................................................................... $\quad 6.7$

6.2.2 Tectonic Breccia ........................................................................................... 6.7

6.2.3 Possible Repeated Section .......................................................................... 6.8

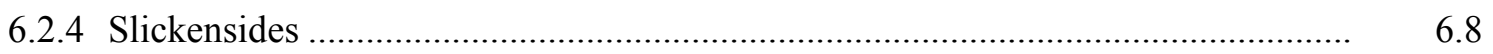

6.2.5 Chalcedony Vein...................................................................................... 6.8

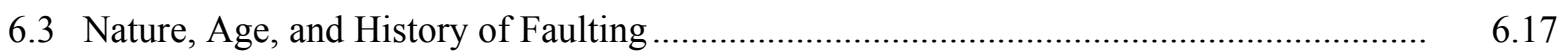

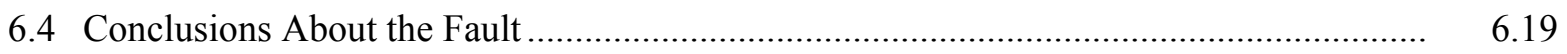

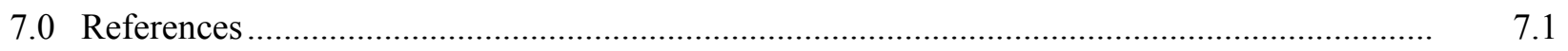

Appendix A - Compositions of Selected Saddle Mountains Basalt and Wanapum Basalt Flow..... $\quad$ A.1

Appendix B - Compositions of Basalt from Waste Treatment Plant Boreholes ............................ B.. B

Appendix C - Secondary Features Observed in Core Hole C4998 _.............................................. C.1

Appendix D - Hydrogeology of the Waste Treatment Plant Site ................................................... D. D 


\section{Figures}

1.1 Locations of the DOE Hanford Site and Waste Treatment Plant .......................................... 1.2

1.2 Locations of Seismic Test Boreholes at the Waste Treatment Plant Site .............................. 1.3

2.1 Generalized Stratigraphy of the Hanford Site and Vicinity............................................... 2.1

2.2 Nomenclature of the Columbia River Basalt Group.......................................................... 2.6

2.3 Stratigraphy of Geologic Units of Interest at the Waste Treatment Plant ........................... 2.7

2.4 Intraflow Structures of Columbia River Basalt Group Lava Flows .................................... 2.9

3.1 Locations of Seismic Test Boreholes at the Waste Treatment Plant Site ............................ 3.2

3.2 Suprabasalt Sediments Between Entry Boreholes.............................................................

3.3 Example of Drill Cuttings from the Ringold Formation Unit A from the Bottom of the C4997 Entry Borehole........................................................................................... 3.5

3.4 An Analogue for Ringold Formation Unit A Exposed Along the White Bluffs, 15 Miles East of the Waste Treatment Plant ..................................................................... 3.6

3.5 Example of Drill Cuttings from the Cold Creek Unit from the C4998 Entry Borehole.......... $\quad 3.7$

3.6 Example of Drill Cuttings from the Gravel-Dominated Hanford Formation from the C4996 Entry Borehole......

3.7 Example of Gravel-Dominated Hanford Formation from Borrow Pit in North Richland, Approximately 15 Miles Southeast of the Waste Treatment Plant.

3.8 Example of Drill Cuttings from the Sand-Dominated Hanford Formation from the C4996 Entry Borehole.

3.9 Sand-Dominated Facies of the Hanford Formation Within the Integrated Disposal Facility Excavation, Approximately 1 Mile Southwest of the Waste Treatment Plant...........

3.10 Example of Drill Cuttings from Recent Deposits and Upper Part of Hanford Formation H2 Unit from the C4996 Entry Borehole

3.11 Composite Borehole Geophysical Logs for Seismic Entry Borehole C4998 ........................ 3.15

3.12 Summary Geologic Log for the C4996 Entry Borehole..................................................... 3.16

3.13 Summary Geologic Log for the C4997 Entry Borehole................................................... 3.18

3.14 Summary Geologic Log for the C4993 Entry Borehole................................................... 3.19

4.1 Umatilla Member Thickness on the Hanford Site and at the Waste Treatment Plant Site.

4.2 Esquatzel Member Thickness on the Hanford Site and at the Waste Treatment Plant Site

4.3 Pomona Member Thickness on the Hanford Site and at the Waste Treatment Plant Site.

4.4 Elephant Mountain Member Thickness on the Hanford Site and at the Waste Treatment Plant Site 
5.1 Mabton Sedimentary Interbed Thickness on the Hanford Site and at the Waste

Treatment Plant Site

5.2 Cold Creek Sedimentary Interbed Thickness on the Hanford Site and at the Waste

Treatment Plant Site .

5.3 Selah Sedimentary Interbed Thickness on the Hanford Site and at the Waste Treatment Plant Site.

5.4 Rattlesnake Ridge Sedimentary Interbed Thickness on the Hanford Site and at the Waste Treatment Plant Site

5.5 Stratigraphic Column of the Mabton Interbed in Core Hole C4998 ......

5.6 Stratigraphic Column of the Cold Creek Interbed in Core Hole C4998............................... 5.10

5.7 Stratigraphic Column of the Selah Interbed from Core Hole C4998 ................................... 5.12

5.8 Stratigraphic Column of the Rattlesnake Ridge Interbed in Core Hole C4998 ..................... 5.13

5.9 North to South Cross Section of the Rattlesnake Ridge Interbed Through the Waste Treatment Plant Site

6.1 Location of the Waste Treatment Plant in the Yakima Fold Belt..

6.2 Generalized Elevation of the Columbia River Basalt Group Beneath the Hanford Site ......... $\quad 6.2$

6.3 Elevation of the Top of the Columbia River Basalt at the Waste Treatment Plant Site..........

6.4 Elevation of the Surface of the Mabton Sedimentary Interbed in Boreholes near and at the Waste Treatment Plant.

6.5 Elevation of the Surface of the Umatilla Member in Boreholes near and at the Waste Treatment Plant

6.6 Elevation of the Surface of the Cold Creek Sedimentary Interbed in Boreholes near and at the Waste Treatment Plant.

6.7 Elevation of the Surface of the Esquatzel Member in Boreholes near and at the Waste Treatment Plant

6.8 Elevation of the Surface of the Selah Sedimentary Interbed in Boreholes near and at the Waste Treatment Plant.

6.9 Elevation of the Surface of the Pomona Member in Boreholes near and at the Waste Treatment Plant

6.10 Elevation of the Surface of the Rattlesnake Ridge Sedimentary Interbed in Boreholes near and at the Waste Treatment Plant.

6.11 Various Features of the Fault Zone in the Pomona Member in Core Hole C4998.

6.12 Chalcedony and Clay/Opal Veins in Suspected Fault Zone at $561.5 \mathrm{ft}$ bgs in Pomona Member

6.13 Relationships at $558.5 \mathrm{ft}$ bgs Indicating Faulting in the Pomona Member...

6.14 High-Angle Fractures Bounding Basalt Breccia and Opaline Matrix at $563.8 \mathrm{ft}$ bgs in Core Hole C4998.

6.15 Photomicrograph of Brecciation at $545.7 \mathrm{ft}$ bgs in Core Hole C4998 Displaying Two Types of Basalt Clasts and Opaline Clasts. 
6.16 Photomicrograph of Brecciation Involving Mostly Clasts of Common Opal ....................... 6.14

6.17 Photomicrograph of a Veinlet in the Chalcedony Vein Showing Brecciation and

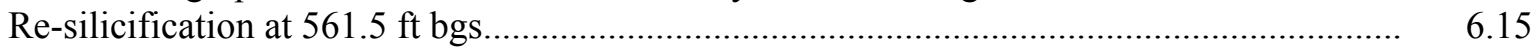

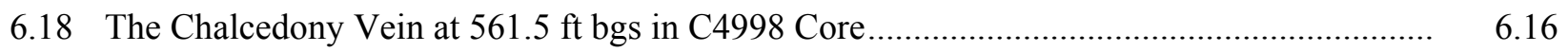

6.19 Slickensides on the Near-Vertical Fracture in the Chalcedony at $561 \mathrm{ft}$ bgs ....................... 6.17

6.20 Small Reverse/Thrust Fault Developed in the Flow Top of an Elephant Mountain Member Flow

\section{Tables}

1.1 Surveyed Horizontal Locations and Elevations of Seismic Boreholes.

2.1 Characteristics of Saddle Mountains Basalt, Upper Wanapum Basalt, and Interbedded Ellensburg Formation at the Waste Treatment Plant Site

3.1 Entry Borehole Features ....

3.2 Suprabasalt Sedimentary Units Encountered at the Waste Treatment Plant Entry Boreholes

4.1 Elevation and Thickness of Columbia River Basalt Group and Ellensburg Formation Units Penetrated by the Waste Treatment Plant Seismic Boreholes

4.2 Depths of Contacts and Intraflow Structures for C4998

4.3 Depths to Basalt Contacts and Intraflow Structures for Mud-Rotary Boreholes

4.4 Depth to Contacts and Thicknesses of Ellensburg Formation Sedimentary Interbeds 


\section{Abbreviations}

$\begin{array}{ll}\text { bgs } & \text { below ground surface } \\ \text { CRBG } & \text { Columbia River Basalt Group } \\ \text { DOE } & \text { U.S. Department of Energy } \\ \text { ID } & \text { inside diameter } \\ \text { km } & \text { kilometer } \\ \text { Ma } & \text { million years ago } \\ \text { my } & \text { million years } \\ \text { OD } & \text { outside diameter } \\ \text { SBP } & \text { Seismic Boreholes Project } \\ \text { TD } & \text { total depth } \\ \text { Vp } & \text { compressional wave velocity } \\ \text { Vs } & \text { shear wave velocity } \\ \text { WTP } & \text { Waste Treatment Plant }\end{array}$




\subsection{Introduction}

During June through October 2006, four deep boreholes were drilled on the site of the Waste Treatment Plant (WTP) at the U.S. Department of Energy (DOE) Hanford Site near Richland, Washington (Figure 1.1). Drilling was conducted to provide information on ground-motion attenuation in the basalt and interbedded sediments underlying WTP site. This report provides the geologic characterization of the sediment above the basalt and of the Columbia River Basalt Group and interbedded sediments penetrated while the three boreholes and one core hole were drilled.

\subsection{Waste Treatment Plant and the Seismic Boreholes Project}

The seismic design basis for the WTP was reevaluated in 2005, resulting in an increase in ground motion by up to $40 \%$ in the seismic design basis. The original seismic design basis for the WTP was established in 1999 based on a probabilistic seismic hazard analysis completed in 1996. The 2005 analysis was performed to address questions raised by the Defense Nuclear Facilities Safety Board about the assumptions used in developing the original seismic criteria and adequacy of the site geotechnical surveys. The updated seismic response analysis used existing and newly acquired seismic velocity data, statistical analysis, expert elicitation, and ground motion simulation to develop interim design ground motion response spectra which enveloped the remaining uncertainties. The uncertainties in these response spectra were enveloped at approximately the 84th percentile to produce conservative design spectra, which contributed significantly to the increase in the seismic design basis.

A key uncertainty identified in the 2005 analysis was the velocity contrasts between the basalt flows and sedimentary interbeds below the WTP. The velocity structure of the upper four basalt flows (Saddle Mountains Basalt) and the interlayered sedimentary interbeds (Ellensburg Formation) produces strong reductions in modeled earthquake ground motions propagating through them. Uncertainty in the strength of velocity contrasts between these basalts and interbeds resulted primarily from an absence of measured shear wave velocities (Vs) in the interbeds. For the 2005 study, Vs in the interbeds was estimated from older limited compressional wave (Vp) data using estimated ranges for the ratio of the two velocities $(\mathrm{Vp} / \mathrm{Vs})$ based on analogues in similar materials. A range of possible $\mathrm{Vs}$ for the interbeds and basalts was used, producing additional uncertainty in the resulting response spectra.

Because of the sensitivity of the calculated response spectra to the velocity contrasts between the basalts and interbedded sediments, DOE initiated the Seismic Boreholes Project (SBP) to emplace additional boreholes at the WTP site and obtain direct measurements of Vs and other physical properties in the Saddle Mountains Basalt and upper Ellensburg Formation. One core hole and three boreholes (Figure 1.2; Table 1.1) were installed at the WTP site to a maximum depth of $1468 \mathrm{ft}$ below ground surface. The three boreholes are within $500 \mathrm{ft}$ of and surround the high-level waste vitrification and pretreatment facilities of the WTP, the Performance Category 3 (PC-3) structures affected by the interim design spectra. The core hole is co-located with the borehole closest to the two PC-3 structures. The new Vs measurements are expected to reduce the uncertainty in the modeled site response caused by the lack of direct knowledge of the Vs contrasts within these layers. 


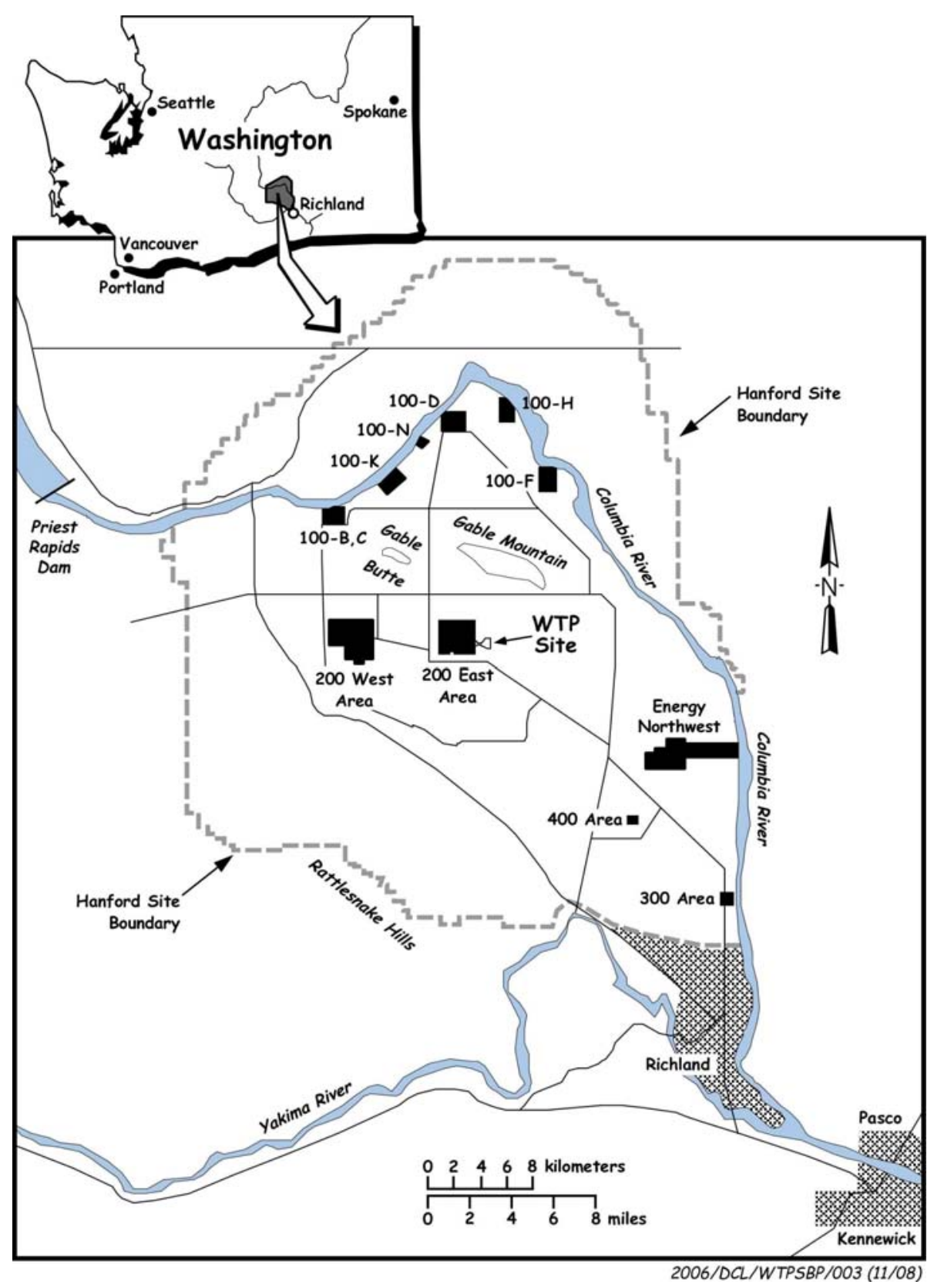

Figure 1.1. Locations of the DOE Hanford Site and Waste Treatment Plant

Table 1.1. Surveyed Horizontal Locations and Elevations of Seismic Boreholes

\begin{tabular}{||c|c|c|c|c|c|c||}
\hline \hline $\begin{array}{c}\text { Hanford } \\
\text { Borehole } \\
\text { ID }\end{array}$ & $\begin{array}{c}\text { WTP Seismic } \\
\text { Location }\end{array}$ & \multicolumn{2}{|c|}{$\begin{array}{c}\text { Surveyed WTP } \\
\text { Coordinates (ft) }\end{array}$} & \multicolumn{2}{|c||}{$\begin{array}{c}\text { Converted - NAD83 State } \\
\text { Plane Coordinates (m) }\end{array}$} & $\begin{array}{c}\text { NAVD88 } \\
\text { Elevation (ft) at } \\
\text { Ground Surface }\end{array}$ \\
\hline \hline C4993 & SW of Site & E 9,647.070 & N 3,840.600 & E 576,087.439 & N 135,756.656 & 658.24 \\
\hline C4996 & NW of Site & E 9,836.490 & N 4,816.880 & E 576,145.168 & N 136,054.191 & 670.06 \\
\hline C4997 & Center of Site & E 10,375.480 & N 3,836.210 & E 576,309.433 & N 135,755.318 & 676.87 \\
\hline C4998 & Center of Site & E 10,345.400 & N 3,920.390 & E 576,300.266 & N 135,780.973 & 676.87 \\
\hline \hline
\end{tabular}




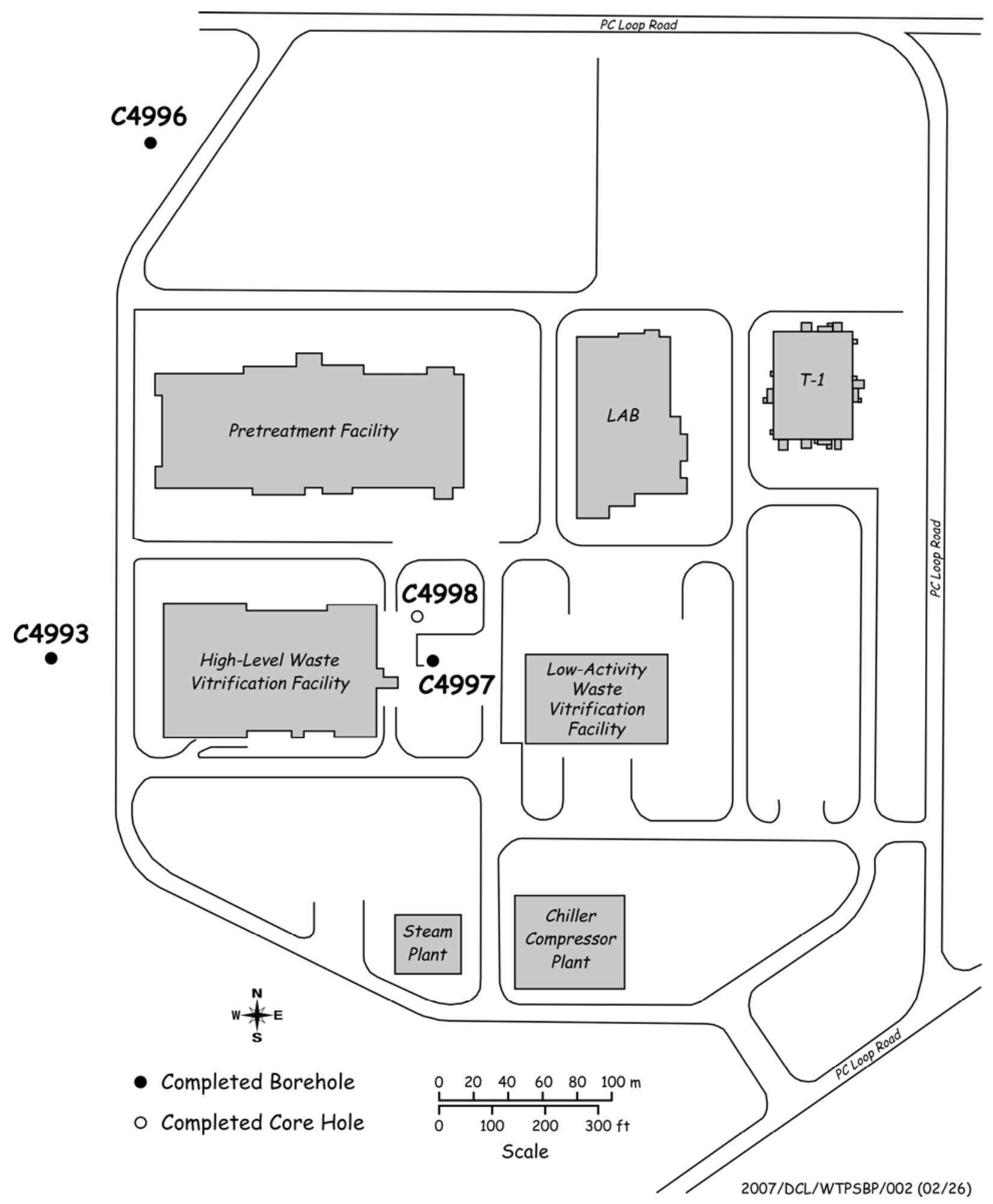

Figure 1.2. Locations of Seismic Test Boreholes at the Waste Treatment Plant Site 


\subsection{Report Scope}

Chapter 2 provides a description of the stratigraphic framework for the overall Hanford Site and the site of the WTP. Contacts for the Ringold and Hanford sediments are provided in Chapter 3; Chapter 4 documents contacts for the basalts and interbedded sediments. Chapter 5 presents a discussion of the Ellensburg Formation that is interbedded with and underlies the Saddle Mountains Basalt in the vicinity of the WTP. The structural geology of the WTP site is detailed in Chapter 6. Chapter 7 provides a list of references cited in the text, followed by Appendixes A through D containing additional supporting data on geologic and hydrogeologic features relevant to the WTP. 


\subsection{Stratigraphic Framework of the Pasco Basin and Hanford Site}

The stratigraphy of the Pacific Northwest is a collection of accreted terrane rocks added onto the North American craton between the Precambrian and early Cenozoic that are now mostly covered by extensive Cenozoic volcanic rocks. Intercalated with the volcanic rocks in structural basins and along the evolving continental margin are sedimentary rocks derived from eroded uplands areas. This chapter provides a description of the stratigraphic framework for the Hanford Site and the WTP.

\subsection{Stratigraphy}

The generalized stratigraphy of the Pasco Basin and Hanford Site is shown in Figure 2.1. The principal rocks exposed at the surface are the Columbia River Basalt Group (CRBG) and intercalated sedimentary rocks of the Ellensburg Formation. These are overlain locally by younger sedimentary rocks of the Ringold Formation and the Pleistocene catastrophic flood deposits of the Hanford formation.

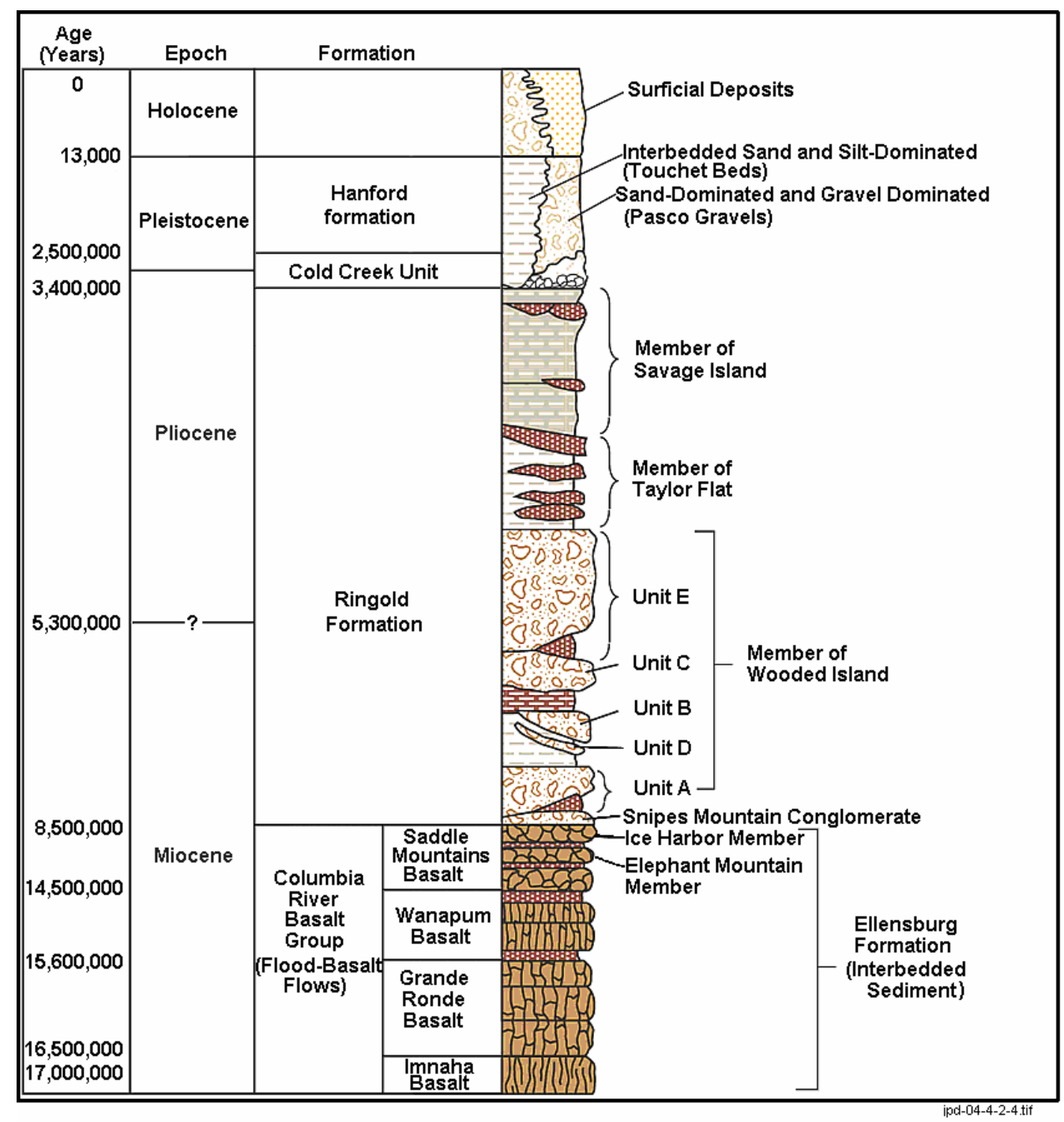

Figure 2.1. Generalized Stratigraphy of the Hanford Site and Vicinity 


\subsubsection{Columbia River Basalt Group}

The Columbia River Basalt Group (CRBG) is a sequence of flood basalt flows that were erupted between 17 and $6 \mathrm{Ma}$. The CRBG covers approximately $230,000 \mathrm{~km}^{2}$ and consists of $200,000 \mathrm{~km}^{3}$ of basalt (Camp et al. 2003). The flows were erupted from north-northwest trending fissures or linear vent systems in north-central and northeastern Oregon, eastern Washington, and western Idaho (Swanson et al. 1979).

The CRBG has been divided into five formations (Figure 2.2) and numerous members (Swanson et al. 1979); only the Grande Ronde Basalt, the Wanapum Basalt, and the Saddle Mountains Basalt are exposed on the Hanford Site. The Imnaha Basalt occurs at the base of the Columbia River Basalt under the Hanford Site and WTP. The Picture Gorge is not present on the Hanford Site.

The basalt flows of the CRBG are recognized using a combination of lithology, chemistry, and paleomagnetic data (Swanson et al. 1979; Table 2.1). Chemical composition and paleomagnetic data have proven to be the most reliable criteria for flow recognition and correlation; lithology is reliable for many flows primarily within the Wanapum and Saddle Mountains Basalts but chemical compositions is often used to confirm identifications.

More than $65 \%$ of the CRBG was erupted in a 1-million year span of the Grande Ronde Basalt. In the field, the Grande Ronde Basalt is divided into four magnetostratigraphic units, which, from oldest to youngest are: Reversed 1, Normal 1, Reversed 2, and Normal 2 (Swanson et al. 1979). The Grande Ronde Basalt is further subdivided into 17 groups of flows or members based on chemical compositions (Figure 2.2; Reidel et al. 1989). The Wanapum Basalt has been subdivided into four members, and the Saddle Mountains Basalt has been subdivided into ten members. The Elephant Mountain Member and Ice Harbor Member are the uppermost basalt lava flows at the Hanford Site. The Elephant Mountain Member is the youngest flow at the WTP.

The younger basalt flows of the Wanapum and Saddle Mountains Basalts on the Hanford Site have been locally eroded to various degrees. Uplift along anticlinal ridges has resulted in erosion to different depths along the margin of the Pasco Basin and Cold Creek syncline. Within the synclines where the basalt surface is covered by sediment fill, the upper basalt flows have been locally eroded by fluvial activity and proglacial flooding. Table 2.1 provides the basic characteristics of the basalt flows and sedimentary interbeds at the Hanford Site that are of concern to this study.

\subsubsection{Ellensburg Formation}

The Ellensburg Formation is intercalated with the CRBG in the Pasco Basin and consists of epiclastic and volcaniclastic sedimentary rocks (Waters 1961; Swanson et al. 1979). The Ellensburg Formation stratigraphy of the Hanford Site has been discussed in detail in Fecht et al. (1987) and Reidel and Fecht (1981). The interbeds of concern to this study and their relationship to the CRBG are shown in Figure 2.3.

Most volcaniclastic material in the Ellensburg Formation was produced by volcanic events in the Cascade Mountains. Deposition was primarily by volcanic debris flows (lahars) and related stream and sheet floods along the western margin of the Columbia Basin. Some air fall and pyroclastic-flow deposits are also present. Farther east in the central Plateau, Ellensburg Formation is mixed with sediments deposited by the ancestral Clearwater and Columbia rivers (Fecht et al. 1987). 
Table 2.1. Characteristics of Saddle Mountains Basalt, Upper Wanapum Basalt, and Interbedded Ellensburg Formation at the Waste Treatment Plant Site

\begin{tabular}{|c|c|c|c|c|c|}
\hline & Formation Unit & General Stratigraphy & Outcrop or Borehole Characteristics & Hand Specimen and Petrographic Characteristics & $\begin{array}{l}\text { Magnetic } \\
\text { Property }\end{array}$ \\
\hline \multirow{2}{*}{ 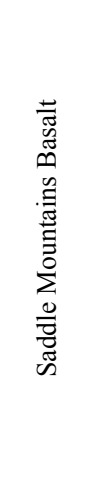 } & $\begin{array}{l}\text { Elephant Mountain } \\
\text { Member II }\end{array}$ & $\begin{array}{l}\text { Unit is } 1 \text { flow (Ward Gap Flow), } \\
\text { up to } 65 \mathrm{ft}(20 \mathrm{~m}) \text { thick, found } \\
\text { throughout the Pasco Basin. Not } \\
\text { present at WTP. }\end{array}$ & $\begin{array}{l}\text { Top: Very vesicular with crude columnar joints. } \\
\text { Entablature: Hackly entablature. } \\
\text { Colonnade: Constitutes half of flow thickness, columns } \\
1.5 \text { to } 2 \mathrm{ft}(0.5 \text { to } 2 \mathrm{~m}) \text { in diameter, platy jointing in } \\
\text { upper part. } \\
\text { Base: Irregular pipe vesicles where flow top is thickest. }\end{array}$ & $\begin{array}{l}\text { Color: Fresh surfaces are black, weathers deep } \\
\text { rust-red or brown. } \\
\text { Phenocrysts: Plagioclase microphyric. } \\
\text { Texture: Fine-to-coarse grained, glassy, } \\
\text { occasionally diktytaxitic. }\end{array}$ & $\begin{array}{l}\text { Transitional } \\
\text { polarity }\end{array}$ \\
\hline & $\begin{array}{l}\text { Elephant Mountain } \\
\text { Member I }\end{array}$ & $\begin{array}{l}\text { Unit is } 1 \text { flow (Yakima Bluffs } \\
\text { flow), up to } 130 \mathrm{ft}(35 \mathrm{~m}) \text { thick, } \\
\text { occurs throughout the Pasco } \\
\text { Basin. This is the only Elephant } \\
\text { Mountain Member flow present at } \\
\text { the WTP. }\end{array}$ & $\begin{array}{l}\text { Top: } 6.5 \text { to } 16 \mathrm{ft} \text { ( } 2 \text { to } 5 \mathrm{~m} \text { ) thick, locally } 1.5 \text { - to } 13 \text {-ft } \\
\text { (0.5- to } 4 \text {-m) thick flow-top breccia. } \\
\text { Entablature: Entablature hackly, } 1.5 \text { - to } 3 \text {-ft }(0.5 \text { - to } \\
\text { 1-meter) thick platy zone at contact with colonnade. } \\
\text { Colonnade: } 3 \text { - to } 7 \text {-ft (1- to } 2 \text {-m) diameter columns. } \\
\text { Base: Pipe vesicles, locally pillowed. } \\
\text { NOTE: Abrupt intraflow facies change in Crab Creek. }\end{array}$ & $\begin{array}{l}\text { Color: Black to dark gray, weathers to a reddish } \\
\text { gray. } \\
\text { Phenocrysts: Plagioclase microphyric. } \\
\text { Texture: Fine-grained, glassy entablature; } \\
\text { occasionally diktytaxitic in colonnade, felty } \\
\text { texture. }\end{array}$ & $\begin{array}{l}\text { Transitional } \\
\text { polarity }\end{array}$ \\
\hline 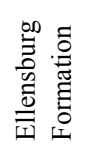 & $\begin{array}{l}\text { Rattlesnake Ridge } \\
\text { Interbed }\end{array}$ & $\begin{array}{l}\text { Unit is } 0 \text { to } 115 \mathrm{ft} \text { ( } 0 \text { to } 9 \mathrm{~m}) \\
\text { thick. Present throughout Pasco } \\
\text { Basin. }\end{array}$ & $\begin{array}{l}\text { Locally cross bedded, clastic dikes, pseudo-columnar } \\
\text { jointing produced by dehydration of clay. }\end{array}$ & $\begin{array}{l}\text { Tuffaceous silt, cream, buff-yellow, gray, well } \\
\text { sorted. }\end{array}$ & NA \\
\hline 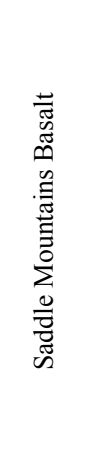 & Pomona Member & $\begin{array}{l}\text { Unit has } 2 \text { or } 3 \text { units, a thin upper } \\
\text { flow and thick lower flow and a } \\
\text { thin lowermost flow known only } \\
\text { from core holes on Gable } \\
\text { Mountain. Upper flow is } 30 \text { to } \\
65 \mathrm{ft}(10 \text { to } 20 \mathrm{~m}) \text { thick; lower } \\
\text { flow is up to } 200 \mathrm{ft}(60 \mathrm{~m}) \text { thick. } \\
\text { Units occur throughout the Pasco } \\
\text { Basin, except when they pinch } \\
\text { out against structures. }\end{array}$ & $\begin{array}{l}\text { Upper Flow: Well-developed colonnade and } \\
\text { entablature. Entablature has fanning columns, } \\
\text { colonnade is locally absent. } \\
\text { Lower Flow: Well-developed colonnade and } \\
\text { entablature. } \\
\text { Top: } 6.5 \text { to } 32 \mathrm{ft} \text { ( } 2 \text { to } 10 \mathrm{~m}) \text { thick, pods of pumice and } \\
\text { glassy fragments. } \\
\text { Entablature: Entablature up to } 30 \mathrm{ft}(10 \mathrm{~m}) \text { thick. 1- to } \\
1.5 \text {-ft }(0.3 \text { - to } 0.5 \text {-m) columns, vertical to fanning, } \\
\text { locally tiered with layers of } 3 \text { - to } 7-\mathrm{ft} \text { (1- to } 2-\mathrm{m}) \\
\text { columns. } \\
\text { Colonnade: Up to } 30 \mathrm{ft}(10 \mathrm{~m}) \text { thick. Base locally } \\
\text { pillowed or peperite, invasive into underlying interbed. }\end{array}$ & $\begin{array}{l}\text { Color: Upper flow gray-black, weathers } \\
\text { brownish-gray. Lower flow blue-black, weathers } \\
\text { brownish-gray. } \\
\text { Phenocrysts: Upper flow has plagioclase and } \\
\text { olivine phenocrysts up to } 0.2 \text { in. ( } 5 \mathrm{~mm}) \text {. Lower } \\
\text { flow has plagioclase phenocrysts up to } 2.5 \mathrm{in} \text {. } \\
(1 \mathrm{~cm}) \text {, sparse olivine phenocrysts up to } 0.02 \mathrm{in} \text {. } \\
(0.5 \mathrm{~mm}) \text { and glomerocrysts of plagioclase and } \\
\text { pyroxene up to } 0.8 \text { in. }(2 \mathrm{~cm}) \text {. Distinctive sieve- } \\
\text { textured plagioclase phenocrysts. } \\
\text { Texture: Both upper and lower flows fine- to } \\
\text { medium-grained, locally microvesicular to } \\
\text { diktytaxitic. }\end{array}$ & $\begin{array}{l}\text { Reverse } \\
\text { polarity }\end{array}$ \\
\hline 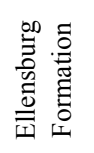 & Selah Interbed & $\begin{array}{l}\text { Unit variable in thickness and } \\
\text { occurs locally in the Pasco Basin. }\end{array}$ & $\begin{array}{l}\text { Vitric tuff, locally fused to perlitic, clean and well } \\
\text { sorted, contains ripple marks. }\end{array}$ & $\begin{array}{l}\text { Silty sand with some volcanic ash, chert and } \\
\text { peperite. Gray to white. }\end{array}$ & NA \\
\hline
\end{tabular}


Table 2.1. (contd)

\begin{tabular}{|c|c|c|c|c|c|}
\hline & Formation Unit & General Stratigraphy & Outcrop or Borehole Characteristics & Hand Specimen and Petrographic Characteristics & $\begin{array}{l}\text { Magnetic } \\
\text { Property }\end{array}$ \\
\hline 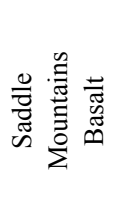 & Esquatzel Member & $\begin{array}{l}\text { Unit is up to } 130 \mathrm{ft}(30 \mathrm{~m}) \text { thick } \\
\text { and restricted to the central and } \\
\text { eastern Pasco Basin. }\end{array}$ & $\begin{array}{l}\text { Top: } 6.5 \text { to } 16 \mathrm{ft}(2 \text { to } 5 \mathrm{~m}) \text { thick. } \\
\text { Entablature: Hackly entablature. } \\
\text { Colonnade: Well developed, } 3 \mathrm{ft}(1 \mathrm{~m}) \text { across columns. } \\
\text { Base: Almost aphanitic with glass chill zone. }\end{array}$ & $\begin{array}{l}\text { Color: Blue-black fresh, weathers a distinctive } \\
\text { brownish color. } \\
\text { Phenocrysts: Scattered plagioclase phenocrysts } \\
0.1 \text { in. }(3 \mathrm{~mm}) \text { up to } 0.6 \text { in. }(1.5 \mathrm{~cm}) \text {. } \\
\text { Texture: Fine grained to diktytaxitic. } \\
\text { NOTE: Microvesicular bands parallel to flow surface. }\end{array}$ & $\begin{array}{l}\text { Normal } \\
\text { polarity }\end{array}$ \\
\hline 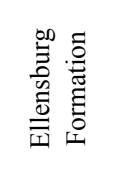 & Cold Creek Interbed & $\begin{array}{l}\text { Unit is } 0 \text { to } 115 \mathrm{ft}(0 \text { to } 35 \mathrm{~m}) \\
\text { thick. Few surface exposures, best } \\
\text { developed in central Pasco Basin } \\
\text { core holes. }\end{array}$ & See Hand Specimen and Petrographic Characteristics. & $\begin{array}{l}\text { Tuffaceous to arkosic sandstone with a middle } \\
\text { conglomerate of well-rounded and closely packed } \\
\text { basalt cobbles in a black basaltic-sand matrix. In } \\
\text { places, weakly cemented, andesitic gravels with } \\
\text { alteration rims. }\end{array}$ & NA \\
\hline \multirow{3}{*}{ 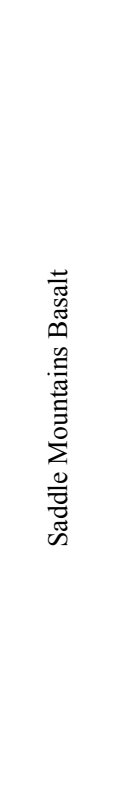 } & Asotin Member & $\begin{array}{l}\text { Unit is up to } 200 \mathrm{ft}(60 \mathrm{~m}) \text { thick } \\
\text { and occurs as intracanyon flows, } \\
\text { but locally sheet-like in the Pasco } \\
\text { Basin. As many as } 3 \text { flows or } \\
\text { units. }\end{array}$ & $\begin{array}{l}\text { Top: Thin scoria. } \\
\text { Entablature: Well-developed, hackly entablature. } \\
\text { Colonnade: Columns up to } 3 \mathrm{ft}(1 \mathrm{~m}) \text { in diameter. } \\
\text { Base: Local minor pillowing. }\end{array}$ & $\begin{array}{l}\text { Color: Black to gray, weathers gray. } \\
\text { Phenocrysts: Plagioclase phenocrysts } \\
\text { (approximately } 1 \text { percent) up to } 0.5 \text { in. }(1 \mathrm{~cm}) \text { and } \\
\text { olivine up to } 0.02 \text { in. }(0.5 \mathrm{~cm}) \text {. } \\
\text { Texture: Ophitic to diktytaxitic. }\end{array}$ & $\begin{array}{l}\text { Normal } \\
\text { polarity }\end{array}$ \\
\hline & $\begin{array}{l}\text { Wilbur Creek } \\
\text { Member }\end{array}$ & $\begin{array}{l}\text { Wahluke Flow. Unit is up to } 100 \mathrm{ft} \\
(30 \mathrm{~m}) \text { thick and occurs as } \\
\text { intracanyon flow in Pasco Basin. } \\
\text { Sheet-like flow on east side of } \\
\text { Saddle Mountains (Eagle Lake } \\
\text { flow of Swanson and others } \\
\text { [1980]). Source area is east of } \\
\text { Pasco Basin. }\end{array}$ & $\begin{array}{l}\text { Top: Unknown from outcrop. } \\
\text { Entablature: Thin, hackly entablature. } \\
\text { Colonnade: Massive columns up to } 3 \mathrm{ft} \text { (1 meter) in } \\
\text { diameter. } \\
\text { Base: Local minor pillowing. }\end{array}$ & $\begin{array}{l}\text { Color: Black to blue-black, weathers gray-black. } \\
\text { Phenocrysts: Sparse plagioclase phenocrysts up to } \\
0.5 \text { in. }(1 \mathrm{~cm}) \text {. } \\
\text { Texture: Generally fine-grained and glassy, rare } \\
\text { plagioclase phenocrysts. } \\
\text { NOTE: Resembles Umatilla, also has concoidal } \\
\text { fracture. }\end{array}$ & $\begin{array}{l}\text { Normal } \\
\text { polarity }\end{array}$ \\
\hline & Umatilla Member & $\begin{array}{l}\text { One to } 2 \text { flows or flow lobes. Unit } \\
\text { is up to } 300 \mathrm{ft}(90 \mathrm{~m}) \text { thick, locally } \\
\text { thinner across structures } 50 \mathrm{ft} \\
(15 \mathrm{~m}) \text { to absent. Unit pinches out } \\
\text { between Umtanum Ridge-Gable } \\
\text { Mountain and Saddle Mountains. }\end{array}$ & $\begin{array}{l}\text { Top: Up to } 32 \mathrm{ft}(10 \mathrm{~m}) \text { thick, locally scoriaceous with } \\
\text { cobbles, clinker, and flow-banded fragments. Almond- } \\
\text { shaped vesicles } 0.3 \text { to } 1.5 \text { in. }(1 \text { to } 4 \mathrm{~cm}) \text {. } \\
\text { Entablature: Distinctive hackly entablature, commonly } \\
\text { makes up } 80 \text { percent of flow. } \\
\text { Colonnade: Thin, but where found has a slabby to } \\
\text { prismatic vertical jointing. } \\
\text { Base: Locally pillowed, up to } 100 \mathrm{ft}(30 \mathrm{~m}) \text { in Cold } \\
\text { Creek syncline. }\end{array}$ & $\begin{array}{l}\text { Color: Black, weathers pseudo-palagonite yellow- } \\
\text { orange, shades of red, blue, or varicolored. } \\
\text { Phenocrysts: Aphyric, rare phenocrysts to } 0.3 \mathrm{in} . \\
(0.7 \mathrm{~cm}) \text {. } \\
\text { Texture: Fine-grained, glassy, dense, plagioclase } \\
\text { laths to } 0.3 \text { in. }(0.7 \mathrm{~cm}) \text { coarse-grained and glassy in } \\
\text { the entablature, "felted texture" and } 0.5 \text { in. }(1 \mathrm{~mm}) \\
\text { equant plagioclase in entablature. } \\
\text { NOTE: Conchoidal fracture. }\end{array}$ & $\begin{array}{l}\text { Normal } \\
\text { polarity }\end{array}$ \\
\hline
\end{tabular}


Table 2.1. (contd)

\begin{tabular}{|c|c|c|c|c|c|}
\hline & Formation Unit & General Stratigraphy & Outcrop or Borehole Characteristics & Hand Specimen and Petrographic Characteristics & $\begin{array}{l}\text { Magnetic } \\
\text { Property }\end{array}$ \\
\hline 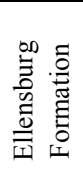 & Mabton Interbed & $\begin{array}{l}\text { Unit is up to } 170 \mathrm{ft}(45 \mathrm{~m}) \\
\text { thick and crops out only on } \\
\text { western margin of Pasco } \\
\text { Basin; otherwise known only } \\
\text { from boreholes. }\end{array}$ & Tuffaceous silt with red and purple opal near top. & See Outcrop or Borehole Characteristics. & NA \\
\hline \multirow[t]{2}{*}{ 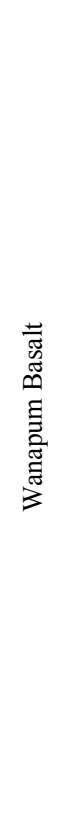 } & $\begin{array}{l}\text { Priest Rapids } \\
\text { Member }\end{array}$ & $\begin{array}{l}\text { Unit is } 160 \text { to } 260 \mathrm{ft} \text { ( } 50 \text { to } \\
80 \mathrm{~m} \text { ) thick, individual flows } \\
\text { are up to } 200 \mathrm{ft}(60 \mathrm{~m} \text { ) thick. } \\
\text { Unit is composed of } 2 \text { flows } \\
\text { throughout most of the Pasco } \\
\text { Basin Lolo flow, upper and } \\
\text { Rosalia flow, lower, but } \\
4 \text { flows or flow lobes in } \\
\text { northwestern part. Not } \\
\text { present in the Wallula Gap } \\
\text { area. A sedimentary interbed, } \\
\text { The Byron Interbed, occurs } \\
\text { locally between upper and } \\
\text { lower facies. }\end{array}$ & $\begin{array}{l}\text { Top: Contains petrified wood locally, upper flow is } \\
\text { deeply weathered. } \\
\text { Entablature: Well developed with hackly jointing in } \\
\text { entablature in the northern part of the Pasco Basin. } \\
\text { Colonnade: Well-developed, massive columns common } \\
1.5 \text { to } 5 \mathrm{ft}(0.5 \text { to } 1.5 \mathrm{~m}) \text { curvi-planar to prismatic jointing } \\
\text { and horizontal partings locally present, some vesicle } \\
\text { sheets. }\end{array}$ & $\begin{array}{l}\text { Color: Black to gray-green when fresh; weathers } \\
\text { to rusty brown. } \\
\text { Phenocrysts: Aphyric, but with rare } 0.5 \text { in. }(1 \mathrm{~cm}) \\
\text { plagioclase phenocrysts (a separate area(s), coarse- } \\
\text { grained phase in thicker flows). } \\
\text { Texture: Fine-grained, glassy, dense with } \\
\text { plagioclase laths to } 0.3 \text { in. }(6.7 \mathrm{~cm}) \text { in entablature. } \\
\text { Distinctive conchoidal fracture. Coarse-grained, } \\
\text { glassy, felted texture with equant plagioclase } \\
0.5 \text { in. }(1 \mathrm{~cm}) \text { in colonnade. }\end{array}$ & $\begin{array}{l}\text { Reverse } \\
\text { polarity }\end{array}$ \\
\hline & Roza Member & $\begin{array}{l}\text { Unit is } 100 \text { to } 300 \mathrm{ft} \text { ( } 30 \text { to } \\
60 \text { meters) thick throughout } \\
\text { most of the Pasco Basin, but } \\
\text { thinner on some ridges and } \\
\text { absent in the Wallula Gap } \\
\text { area. Occurs as } 1 \text { to } 2 \text { flows } \\
\text { throughout most of Pasco } \\
\text { Basin, but } 3 \text { flows reported in } \\
\text { the southwest Pasco Basin. }\end{array}$ & $\begin{array}{l}\text { Top: Rubbly, but some crude columnar jointing, local } \\
\text { petrified wood. } \\
\text { Entablature: Poorly developed entablature. } \\
\text { Colonnade: Well developed with pinch and swell } \\
\text { structures common. }\end{array}$ & $\begin{array}{l}\text { Color: Gray-black when fresh; weathers to rusty } \\
\text { brown. } \\
\text { Phenocrysts: Plagioclase phenocrysts, very } \\
\text { porphyritic, evenly distributed, most } 0.2 \text { to } 0.8 \text { in. } \\
(0.5 \text { to } 2 \mathrm{~cm}) \text {. } \\
\text { Texture: Fine- to medium-grained, moderately } \\
\text { diktytaxitic. }\end{array}$ & $\begin{array}{l}\text { Transitional } \\
\text { polarity }\end{array}$ \\
\hline
\end{tabular}




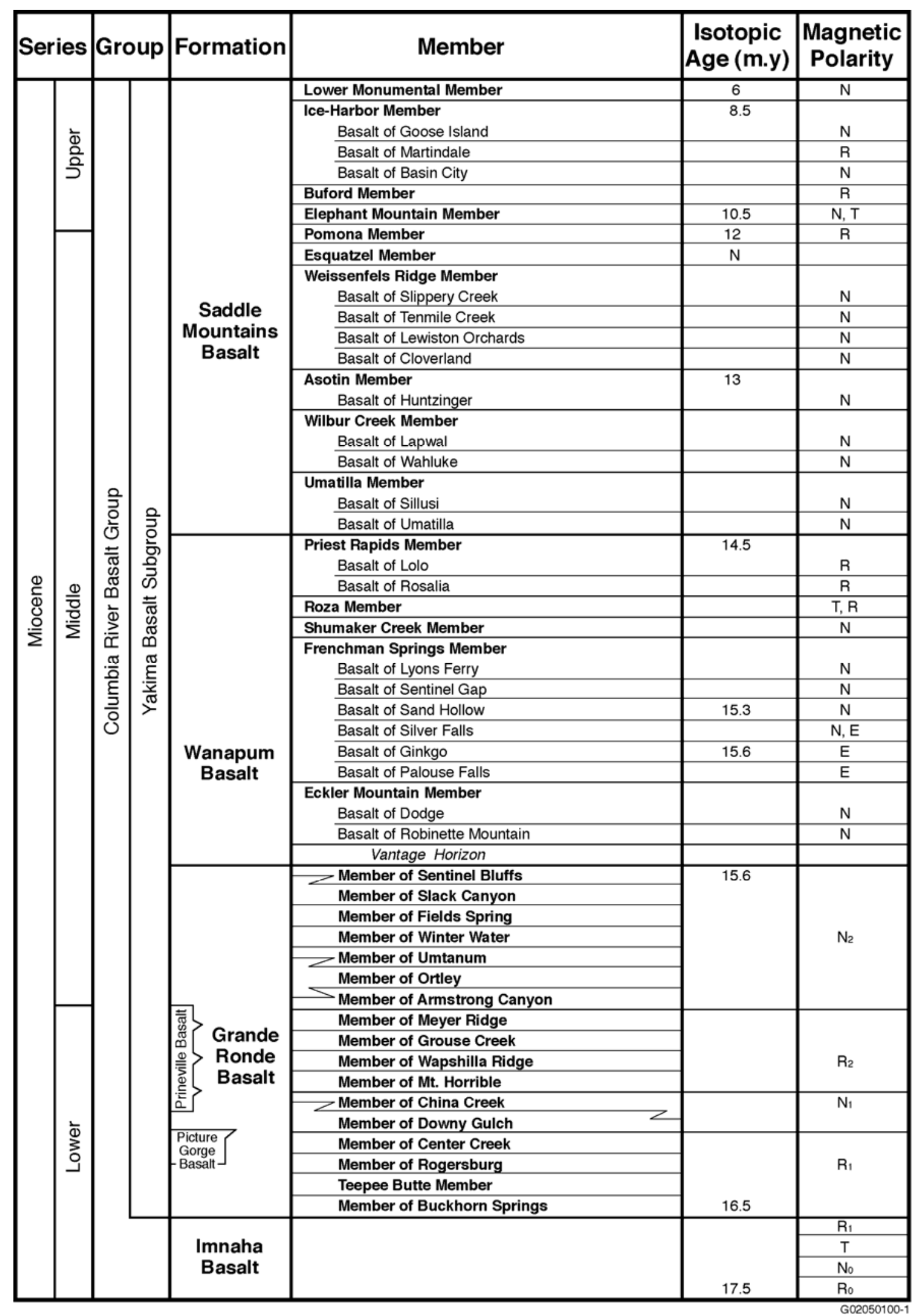

Figure 2.2. Nomenclature of the Columbia River Basalt Group 


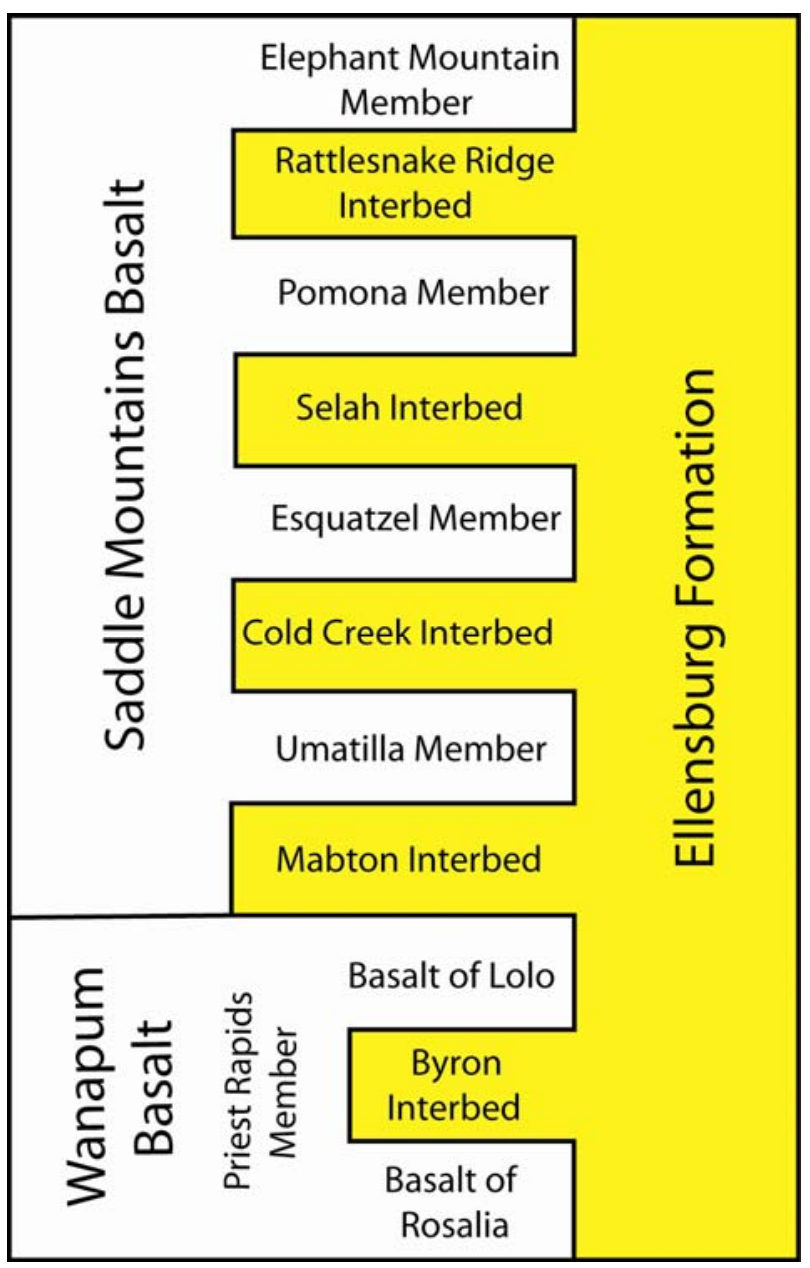

Figure 2.3. Stratigraphy of Geologic Units of Interest at the Waste Treatment Plant

\subsubsection{Post-Columbia River Basalt Group Sediments}

The Hanford Site and WTP are situated on a sequence of sedimentary units that overlie the CRBG. These sediments are confined largely to the synclinal valleys and basins of the western Columbia Basin. The sedimentary record is incomplete, but it is a direct reflection of the structural development of the area (Fecht et al. 1987). The upper Miocene to middle Pliocene record of the Columbia River system in the Columbia Basin is represented by the upper Ellensburg and Ringold Formations, and the Snipes Mountain conglomerate. Except for local deposits (e.g., the Cold Creek unit [CCU] [DOE 1988; DOE-RL 2002]), there is a hiatus (lack of sedimentation or erosion) in the stratigraphic record between the end of the Ringold Formation deposition (3.4 Ma) and the beginning of Pleistocene (1.6 Ma) time.

Pleistocene to Recent sediments overlying the CRBG and the Ringold Formation at the Hanford Site include cataclysmic flood gravels and slackwater sediments of the Hanford formation; terrace gravels of the Columbia, Snake, and Yakima Rivers; and eolian deposits. 


\subsection{Nomenclature and Features of Lava Flows}

The immense size of Columbia River flood-basalt lavas makes it difficult to determine what constitutes a single eruption and what does not. Historically, Columbia River flood-basalt descriptions have used the term cooling unit to describe a lava flow. A single cooling unit is defined as having a flow top and a base that show evidence of more rapid cooling or chilling compared to the interiors (Figure 2.4). Although many of the surface features observed on recent eruptions of pahoehoe lavas have excellent counterparts on flood basalts (e.g., pahoehoe lobes, tumulus, vesicle sheets), some of the nomenclature that has been applied to those eruptions has proven difficult to adapt to flood basalts (Thordaran et al. 1998). For example, in the terminology of Walker (1971), large single lobes as much as $30 \mathrm{~m}$ thick are called simple flows, and many similar-size lobes that total $100 \mathrm{~m}$ thick are called compound flows. Self et al. (1998) have attempted to resolve these differences by refining existing terms and introducing new ones. They define a lobe as the smallest coherent package of lava, a flow as the product of a single outpouring of lava, and a flow field as lava covering a large area that has many separate outpourings. The term lobe is easy to apply but problems still remain recognizing what constitutes a flow or flow field.

The concept of inflated lava flows has also become important to models describing emplacement of flood-basalt lavas. Hon et al. (1994) described inflated flows from Hawaii where they documented the growth and inflation of lobes of lava by the internal injection of more lava. With each pulse of new lava, the flow grows thicker. Flows advance by breakouts at the front of the flow. As more lava erupts it causes inflation of flows and break outs of new lava at the flow front.

\subsubsection{Internal Basalt Flow Features}

Intraflow structures are primary internal features or stratified portions of basalt flows exhibiting grossly uniform macroscopic characteristics. These features originate during the emplacement and solidification of each flow and result from variations in cooling rates, degassing, thermal contraction, and interaction with surface water. They are distinct from features formed by tectonic processes.

CRBG flows typically consist of a flow top, a dense, flow interior, and a flow bottom of variable thickness. Figure 2.4 shows the types of intraflow structures that are typically observed in a basalt flow; most flows do not show a complete set of these structures.

The flow top is the chilled, glassy upper crust of the flow. It may consist of vesicular to scoriaceous basalt, displaying either pahoehoe or aa characteristics, or it may be rubbly to brecciated (Swanson and Wright 1981). Typically, the flow top comprises approximately $10 \%$ of the thickness of a flow; however, it can be as thin as a few centimeters. Almost all CRBG flows display pahoehoe features; some have rubbly to brecciated flow tops, but none is considered to represent aa flows.

Flow-top breccias occur as zones of angular to subrounded, broken volcanic rock fragments that may or may not be supported by a matrix and are located adjacent to the upper contacts of the lava flows. A mixture of vesicular and nonvesicular clasts bound by basaltic glass often characterizes the breccia zone. The percentage of the breccia to rubbly surface is typically less than $30 \%$ but locally can be as much as $50 \%$ of the flow. This type of flow top usually forms from a cooled top that is broken up and carried along with the lava flow before it ceases movement. 


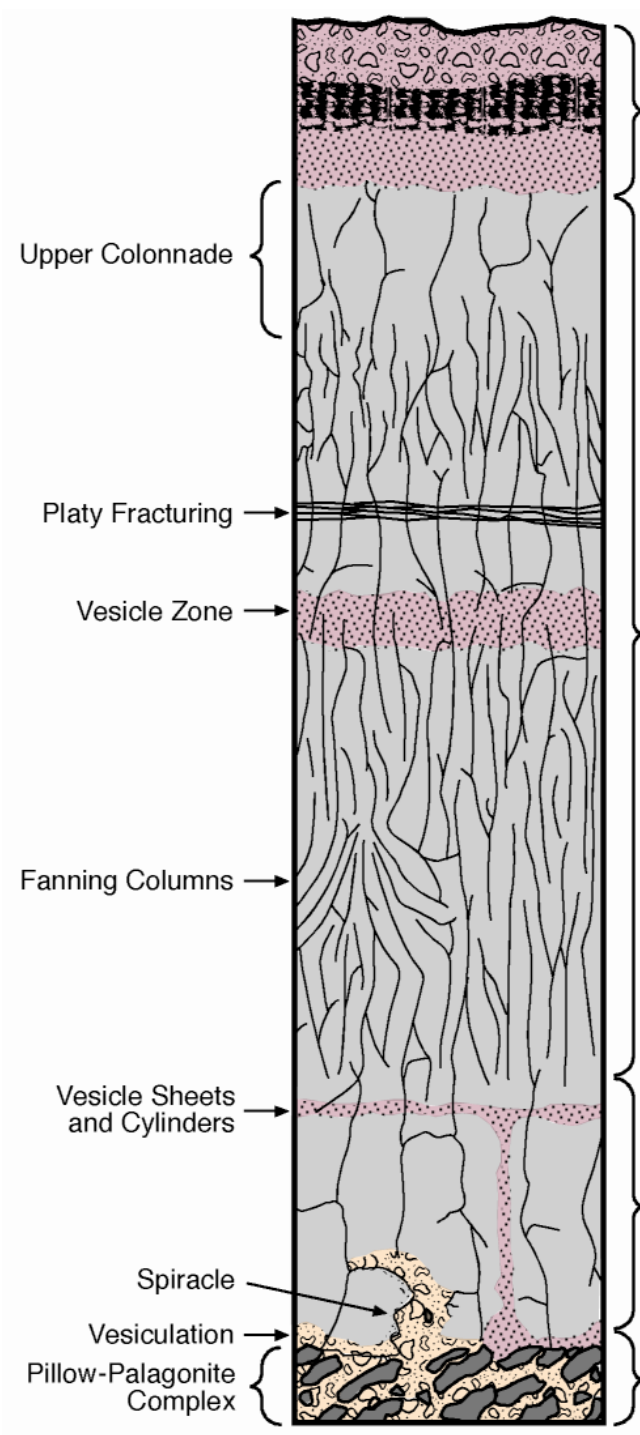

FLOW TOP ZONE

Vesicular to rubbly and/or

brecciated basalt. May have

characteristics of pahoehoe

or AA flows

ENTABLATURE

COLONNADE

FLOW BOTTOM ZONE

Can be pillow-palagonite

complex, hyaloclastite, etc. or just a vesicular base, rubble, or breccia.

\section{FLOW INTERIOR}

Figure 2.4. Intraflow Structures of Columbia River Basalt Group Lava Flows

The basal part of a CRBG lava flow is predominantly a glassy, chilled zone a few centimeters thick that may be vesicular. Where basalt flows encounter bodies of water or saturated sediments, the following features may occur:

- Pillow-palagonite complexes. Discontinuous pillow-shaped structures of basalt formed as basalt lava flows into water. The space between the pillows is usually composed of hydrated basaltic glass (palagonite) and hyaloclastite.

- Hyaloclastite complexes. Deposits resembling tuff that form when basalt lava shatters as it flows into water.

- Foreset bedded breccias. These form as basalt lava flows into water and builds out its own delta. Hyaloclastite and pillow-palagonite complexes usually compose the foreset beds.

- Peperites. Breccia-like mixture of basalt (or hyaloclastite or palagonite) and sediment that form as basalt lava burrows into sediments, especially wet sediments. 
- Spiracles. A fumarolic vent-like feature that forms due to a gaseous explosion in fluid lava flowing over water-saturated soils or ground.

Internal fractures or joints in the thick CRBG flows set them apart from other smaller flows. CRBG flows have internal jointing (fractures) that is classed as either entablature or colonnade. Entablature jointing consists of small columns of fine-grained basalt most commonly in the upper parts of the flows that overlie larger columns of coarser basalt that form the colonnade. Entablature columns are defined by fractures with typical spacings of approximately $10 \mathrm{~cm}$; fractures that define the colonnades typically have spacings of about 0.5 to $1 \mathrm{~m}$. These fractures often have secondary mineral infillings with slickensides that indicate movement along the jointing or facture.

The colonnade consists of relatively well-formed polygonal columns of basalt, usually vertically oriented and typically $1 \mathrm{~m}$ in diameter or larger (some as large as $3 \mathrm{~m}$ have been observed). Colonnades, as defined by Tomkeieff (1940), occur in the basal portion of flows. In CRBG flows, the colonnade can make up the entire flow thickness, or there may be one or more colonnades present that are tiered with entablatures.

Zones or layers of vesicles occur in the interior portions of the basalt flows and are physically distinct from a vesicular flow top. These vesicle zones or sheets are nearly ubiquitous in the CRBG lavas. The vesicle zones can range from a few $\mathrm{cm}$ to as much as several meters in thickness. Typically they are transitional between massive basalt above and below, and are not physical boundaries of cooling units or lobes. The vesicle zones have been interpreted as gas trapped by an advancing solidification front (McMillan et al. 1989) and as distinct pulses of a continuing eruption (Walker et al. 1999).

Vesicle sheets are horizontal to subhorizontal layers of vesicles. They typically are fed by vesicle cylinders and form below the solidification front. Vesicle sheets within the interior of thicker flows can be thin (centimeters to meters thick) and can be laterally continuous, sometimes for kilometers.

Vesicle zones are usually thicker than vesicle sheets but probably form in much the same way. Vesicle zones can be up to several meters thick and are typically located in the dense interior of a lava flow.

Vesicle pipes and cylinders are cylindrical zones of gas bubbles that form as gas evolves from lava and rises toward the top of the flow. Pipes and cylinders are distinguished by their size; cylinders are larger, but there is a continuum of sizes between the two. Vesicle cylinders, pipes, and sheets usually occur in relatively thin flows $(5-30 \mathrm{~m})$ composed mainly of colonnades and flow tops.

Pegmatoid zones are areas in a lava flow where the crystals are larger than the normal groundmass crystals. The term pegmatoid is used when the composition of the rock is not granite. These zones usually develop when volatiles become concentrated in a layer allowing the crystals to grow more slowly and larger.

\subsection{Identification of Columbia River Basalt Group Lava Flows}

Lava flows of the CRBG are identified using a combination of stratigraphic position, lithology, paleomagnetic properties, and chemical composition. The chemical composition provides the least ambiguous way of properly identifying a lava flow. Table A.1 (Appendix A) shows the chemical 
composition of the larger lava flows of the CRBG and the ones of most importance at the WTP. Chemical analyses of basalt samples obtained for information only from core hole $\mathrm{C} 4998$ and boreholes C4993 and C4996 are given in Table B.1 (Appendix B).

Typically $\mathrm{TiO}_{2}, \mathrm{P}_{2} \mathrm{O}_{5}$, and $\mathrm{MgO}$ provide the most reliable indicators used to identify flows. Saddle Mountains Basalt flows are some of the most distinct chemically and have a wider range in composition. Wanapum Basalt flows are typically characterized by higher $\mathrm{FeO}$ and $\mathrm{TiO}_{2}$ contents in Saddle Mountains flows. Grande Ronde Basalt flows are generally chemically similar, and it is difficult to distinguish individual flows.

\subsection{Contacts in Boreholes}

Determining the exact contact between geologic units in a core hole is easy because of the continuous core recovered. Contacts in boreholes drilled by rotary and cable-tool methods can be difficult to determine because these drilling methods produce cuttings that are brought to the surface with a drive barrel or circulated with mud.

\subsubsection{Geologists' and Drillers’ Logs}

By far the main factor affecting accuracy of a geologic contact is the geologist's log. Core hole geologists' logs will be the most accurate because a continuous to nearly continuous record of strata is retrieved. Mud-rotary and cable-tool geologists' logs are less accurate than the core hole logs. This is because chip samples (cutting) are returned via the drive barrel or mud system. There is a time lag between when the bit cuts the samples and when the samples are brought to the surface. In a mud-rotary system, some amount of mixing of cuttings from different depths will occur as the cuttings are brought to the surface. Thus geologists' logs from the mud-rotary drilling are the best estimation of contacts based on the geologists' interpretation of all drilling factors.

\subsubsection{Geophysical Logs}

A combined geologist's log and geophysical log offers the highest quality information for interpreting contacts and features of the subsurface. The contacts provided in this report for basalts and interbedded sediments are based on the well-site geologists' logs with modifications based on the geophysical logs provided in Gardner and Price (2007). Chapter 3 provides contacts for the Ringold and Hanford sediments, and Chapter 4 provides contacts for the basalts and interbedded sediments. 


\subsection{Suprabasalt Sediments from Entry Boreholes at the Waste Treatment Plant}

Four entry boreholes were drilled via the cable-tool method at the WTP through the suprabasalt sediments for seismic data collection. The entry boreholes extend from surface to approximately $20 \mathrm{ft}$ below the top of basalt bedrock. A summary of the cased entry boreholes is provided in Table 3.1, and the locations are shown in Figure 3.1. Drilling and sampling information as well as geologists' logs, geophysical logs, and high-resolution photographs of cuttings recovered from the four entry boreholes are presented in Horner (2007).

Samples were collected from the entry boreholes to identify and characterize the geologic units that underlie the WTP site and to determine seismic properties of the post-basalt sediments. All drilling data in this chapter are presented in the units that they were measured in the field.

Table 3.1. Entry Borehole Features

\begin{tabular}{|c|c|c|c|c|}
\hline \multirow{2}{*}{$\begin{array}{c}\text { Well } \\
\text { Name/Well ID } \\
\end{array}$} & \multicolumn{2}{|c|}{ Drilling Date } & \multirow{2}{*}{$\begin{array}{c}\text { Ground Surface } \\
\text { Elevation (ft) }\end{array}$} & \multirow{2}{*}{$\begin{array}{l}\text { Total Entry Depth } \\
\text { (ft bgs) }\end{array}$} \\
\hline & Start & Finish & & \\
\hline C4993 & $8 / 21 / 06$ & $9 / 4 / 06$ & 658.24 & 383.5 \\
\hline C4996 & $7 / 12 / 06$ & $7 / 27 / 06$ & 670.06 & 369 \\
\hline C4997 & $7 / 30 / 06$ & $8 / 18 / 06$ & 676.87 & 401 \\
\hline C4998 & $6 / 12 / 06$ & $7 / 10 / 06$ & 676.87 & 401.5 \\
\hline
\end{tabular}

\subsection{Suprabasalt Sediments}

The suprabasalt sediments at the WTP consist of, from oldest to youngest, 1) Ringold Formation, 2) Cold Creek Unit, which is reworked Ringold Formation, 3) Hanford formation, and 4) recent deposits (Figure 3.2). These stratigraphic units are best differentiated on the basis of grain size, percentage of basalt rock fragments, and color. Other useful criteria for differentiating units include grain sorting, bedding structure, and roundness.

\subsubsection{Ringold Formation (Unit A)}

Ringold Formation Unit A represents ancient alluvial deposits laid down within the subsiding Cold Creek syncline after emplacement of the Elephant Mountain Member of the Columbia River Basalt Group, 10.5 million years ago (DOE 1988; Lindsey 1995, 1996). The unit ranges from 45 to $68 \mathrm{ft}$ thick beneath the WTP (Table 3.2, Figure 3.2). Unit A belongs to Lindsey's (1995) Facies Association I and part of the member of Wooded Island, Ringold Formation. The unit consists of mostly clast-supported sandy gravel to silty sandy gravel. Clay and silt content varies, and appears to depend on degree of secondary weathering and diagenesis. Ringold Unit A is distinctly bimodal; one mode of pebble to cobble size clasts and the other of fine to medium sand. Particles within these modes are generally moderately to well sorted. Gravel clasts are mostly rounded to well rounded, frequently smoothed and polished, and multilithic, with only $20-40 \%$ basalt content. Other lithologues are mostly quartizite and gneiss, as well as a wide variety of plutonic and silicic to intermediate volcanic lithologies. The sand fraction is mostly quartzo-feldspathic and limited to 5-20\% mafic grains. All these characteristics are consistent with an ancestral Columbia-Snake River origin for Ringold Formation Unit (Lindsey 1995). 


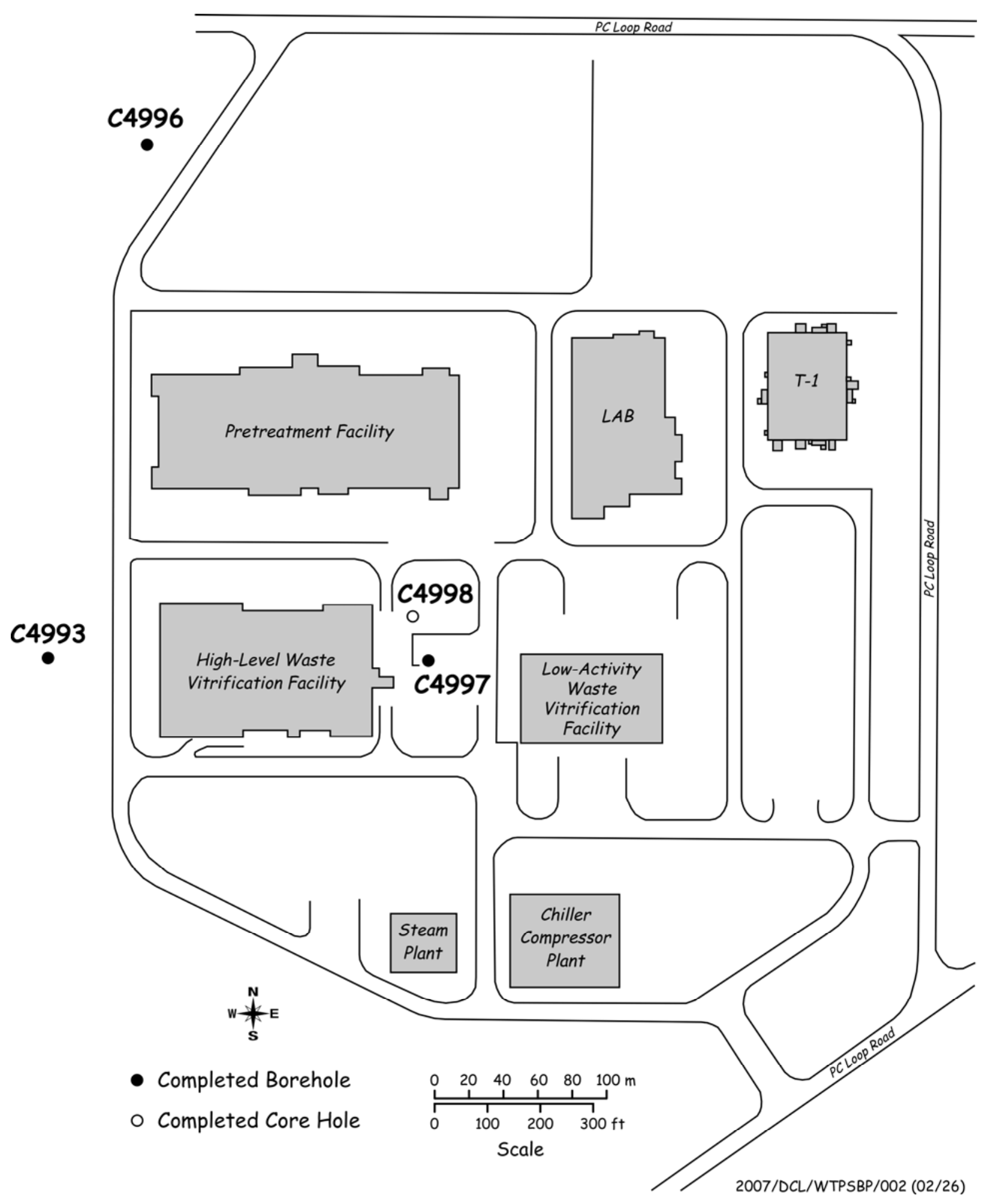

Figure 3.1. Locations of Seismic Test Boreholes at the Waste Treatment Plant Site 
Suprabasalt Sediments Between Entry Boreholes

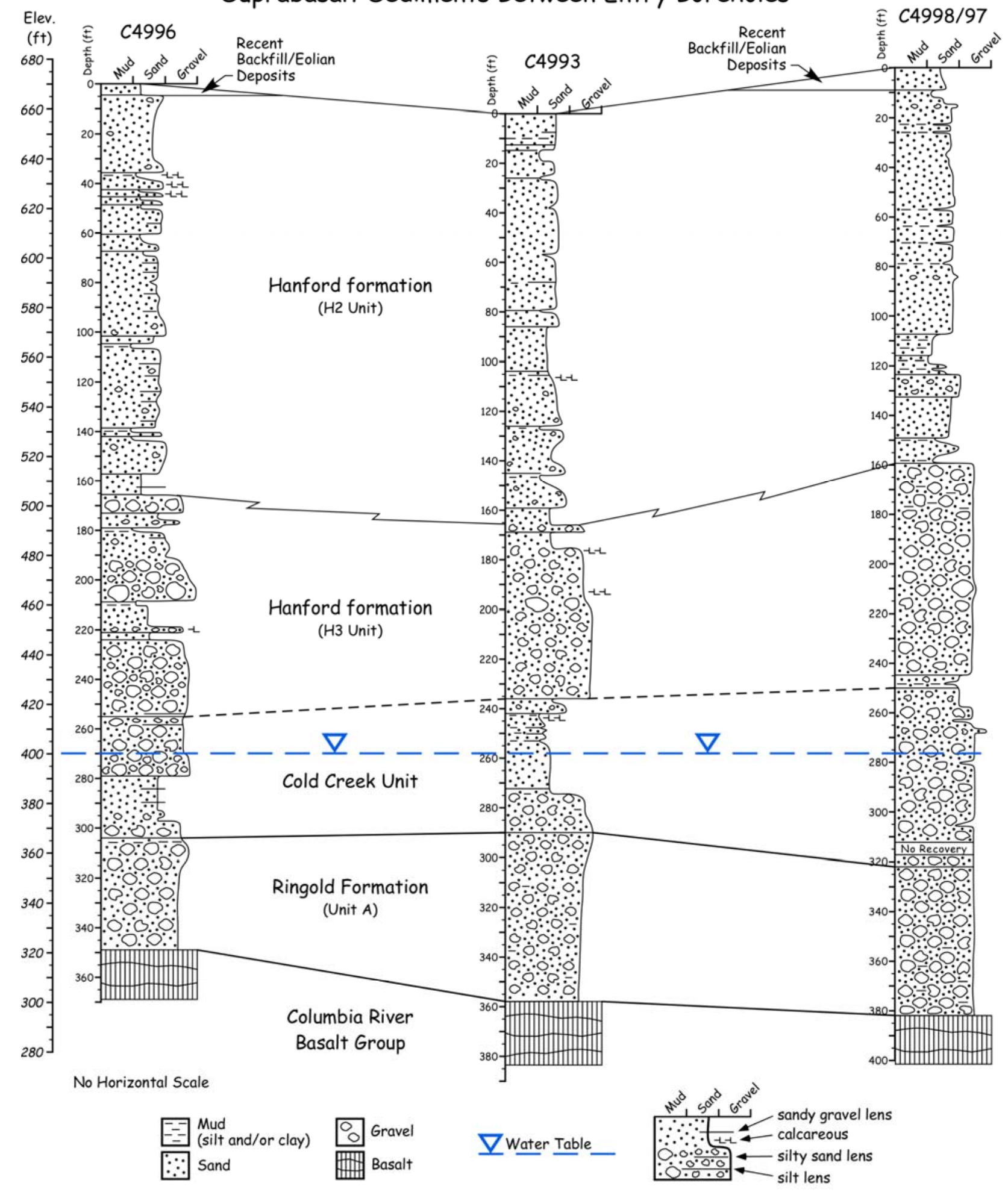

2007/DCL/WTPSB/001 (04/18)

Figure 3.2. Suprabasalt Sediments Between Entry Boreholes 
Depths and thicknesses of the suprabasalt stratigraphic units are presented in Table 3.2.

Table 3.2. Suprabasalt Sedimentary Units Encountered at the Waste Treatment Plant Entry Boreholes

\begin{tabular}{|c|c|c|c|c|c|c|c|c|}
\hline Borehole ID & \multicolumn{2}{|c|}{ C4998 } & \multicolumn{2}{|c|}{ C4996 } & \multicolumn{2}{|c|}{ C4997 } & \multicolumn{2}{|c|}{ C4993 } \\
\hline $\begin{array}{l}\text { Surface } \\
\text { Elevation }\end{array}$ & \multicolumn{2}{|c|}{676.87} & \multicolumn{2}{|c|}{670.06} & \multicolumn{2}{|c|}{676.87} & \multicolumn{2}{|c|}{658.24} \\
\hline Unit & $\begin{array}{c}\text { Thickness } \\
\text { (ft) }\end{array}$ & $\begin{array}{l}\text { Drilled } \\
\text { Depth }^{(a)}\end{array}$ & $\begin{array}{c}\text { Thickness } \\
\text { (ft) }\end{array}$ & $\begin{array}{l}\text { Drilled } \\
\text { Depth }^{(\text {a) }}\end{array}$ & $\begin{array}{c}\text { Thickness } \\
\text { (ft) }\end{array}$ & $\begin{array}{l}\text { Drilled } \\
\text { Depth }^{(\text {a) }}\end{array}$ & $\begin{array}{c}\text { Thickness } \\
\text { (ft) }\end{array}$ & $\begin{array}{l}\text { Drilled } \\
\text { Depth }^{(a)}\end{array}$ \\
\hline $\begin{array}{l}\text { Suprabasalt } \\
\text { Sediments }\end{array}$ & 382 & 0 & 349 & 0 & 383 & 0 & 358 & 0 \\
\hline Backfill/Eolian & 9 & 0 & 4.5 & 0 & 16.8 & 0 & 0.3 & 0 \\
\hline $\begin{array}{l}\text { Hanford Fm. - } \\
\text { H2 Unit }\end{array}$ & 150.5 & 9 & 161 & 4.5 & 149.2 & 16.8 & 165.7 & 0.3 \\
\hline $\begin{array}{l}\text { Hanford Fm. - } \\
\text { H3 Unit }\end{array}$ & 90.5 & 159.5 & 89.5 & 165.5 & 89.5 & 166 & 70 & 166 \\
\hline $\begin{array}{l}\text { Cold Creek } \\
\text { Unit }\end{array}$ & 72 & 250 & 49 & 255 & 63.5 & 255.5 & 54 & 236 \\
\hline $\begin{array}{l}\text { Ringold Fm. } \\
\text { Unit A }\end{array}$ & 60 & 322 & 45 & 304 & 64 & 319 & 68 & 290 \\
\hline Basalt & & 382 & & 349 & & 383 & & 358 \\
\hline
\end{tabular}

The weight of up to $600 \mathrm{ft}$ of overlying sediments in combination with diagenetic alteration through long-term interactions with groundwater, resulted in Ringold Formation Unit A sediments that today are moderately to strongly weathered, compacted and consolidated. A significant amount of compaction and consolidation resulted from deep burial by younger Ringold Formation deposits, which at one time filled the Pasco Basin to an elevation of $900 \mathrm{ft}$. Since that time, after a period of late Pliocene incision, much of the Ringold Formation from the center of the basin was backfilled with younger fluvial and glaciofluvial deposits. A long period of in situ weathering via geochemical interactions with groundwater is corroborated based on 1) pervasive iron-oxide stain, resulting in sediment colors that are distinctive shades of red, orange, brown, and yellow (Figure 3.3), 2) alteration clay/silt skins around gravel clasts, and 3) thick weathering rinds on many gravel clasts. Ringold Formation Unit A is generally noncalcareous. Ringold Formation Unit A equivalent sediments are not exposed at the surface anywhere in the Pasco Basin. However, the member of Wooded Island, Ringold Formation, exposed along the White Bluffs within the eastern Pasco Basin (Figure 3.4), is a reasonable analogue.

\subsubsection{Cold Creek Unit}

Older gravel-dominated deposits, herein referred to as the Cold Creek unit, appear to be derived from scouring and reworking of the underlying Ringold Formation. This unit, referred to as "reworked Ringold" in Horner (2007), appears to belong to the coarse-grained, multilithic lithofacies of the Cold Creek unit as described in DOE-RL (2002). The relatively unconsolidated deposits of the Cold Creek unit overlie consolidated sandy gravel from Unit A of the Ringold Formation. Cold Creek unit deposits range from 49 to $72 \mathrm{ft}$ thick beneath the WTP (Table 3.2, Figure 3.2). The Cold Creek unit deposits may be weakly to strongly calcareous. 


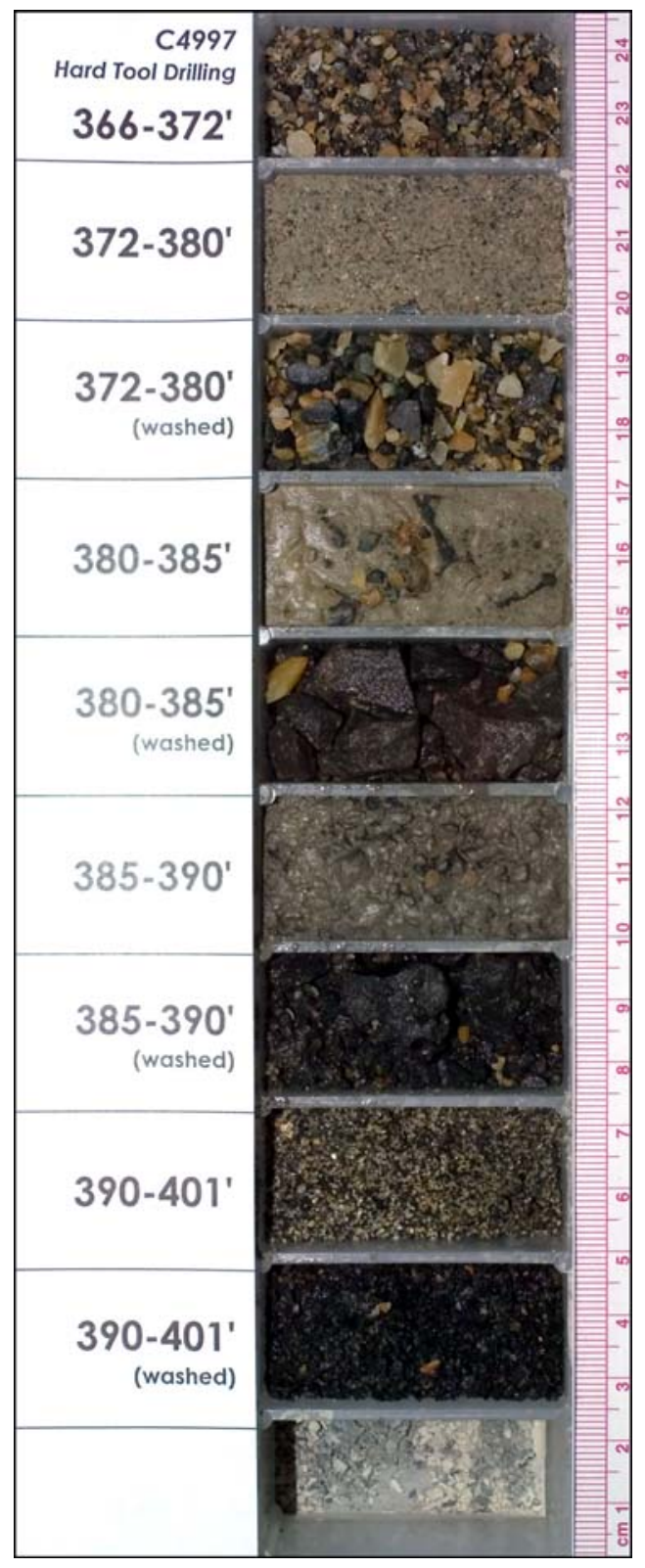

Figure 3.3. Example of Drill Cuttings from the Ringold Formation Unit A from the Bottom of the C4997 Entry Borehole. All the samples in this tray were pulverized during hard-tool drilling and therefore are not representative of the true grain-size distribution. Each sample interval (except 366-372 ft) is shown twice, once before rinsing away of mud generated during drilling and again after rinsing away of fines (washed). Relatively low basalt content and rusty iron-stained color (characteristics of Ringold Unit A), both in the washed and unwashed samples, are visible between 366- to 380-ft depths. The basalt contact at $383 \mathrm{ft}$ is apparent based on the sudden increase in blocky, angular basalt fragments in the 380- to 385$\mathrm{ft}$ (washed) sample. 


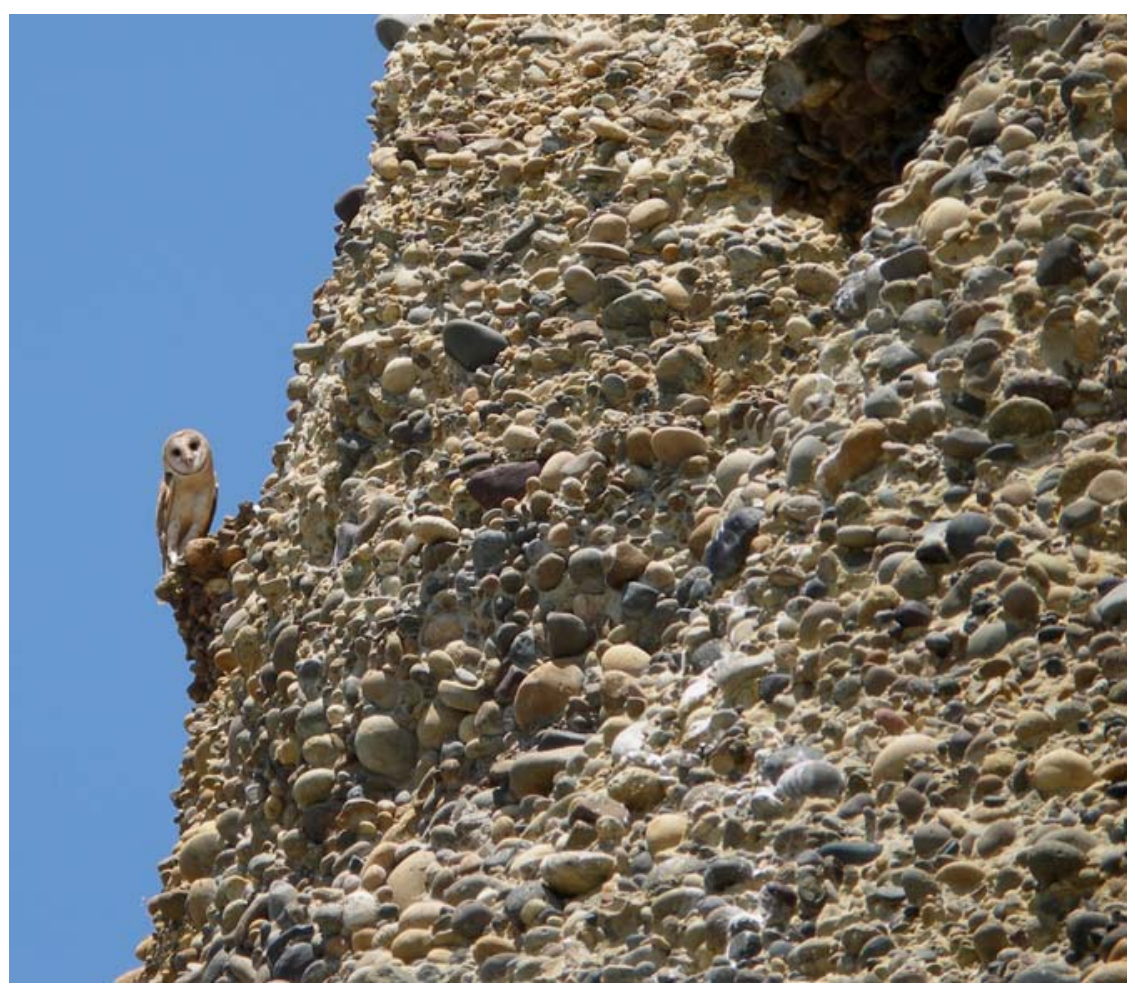

Figure 3.4. An Analogue for Ringold Formation Unit A Exposed Along the White Bluffs, 15 Miles East of the Waste Treatment Plant. Note bimodal texture of clast-supported pebble-cobble conglomerate within matrix of well-sorted, fine to medium sand. Also note pervasive rusty colored, iron-oxide stain. Gravel clasts, composed of only 10-20\% basalt, are well-rounded and polished, characteristic of a fluvial deposit.

Like the Ringold Formation, the Cold Creek unit is clast-supported and multilithic. However, the color is very different between these two stratigraphic units. The color difference is probably due to a significantly younger age for the Cold Creek unit. Because of its younger age, the Cold Creek unit deposits are significantly less weathered and lack pervasive iron-oxide stain (Figure 3.5) characteristic of intact Ringold Formation Unit A. Instead, colors of the Cold Creek unit appear as light and "bleached" shades of gray, olive, or brown. The percentage of basalt rock fragments in the Cold Creek unit ranges from 20 to $50 \%$, which is intermediate between the Ringold and Hanford formations. 


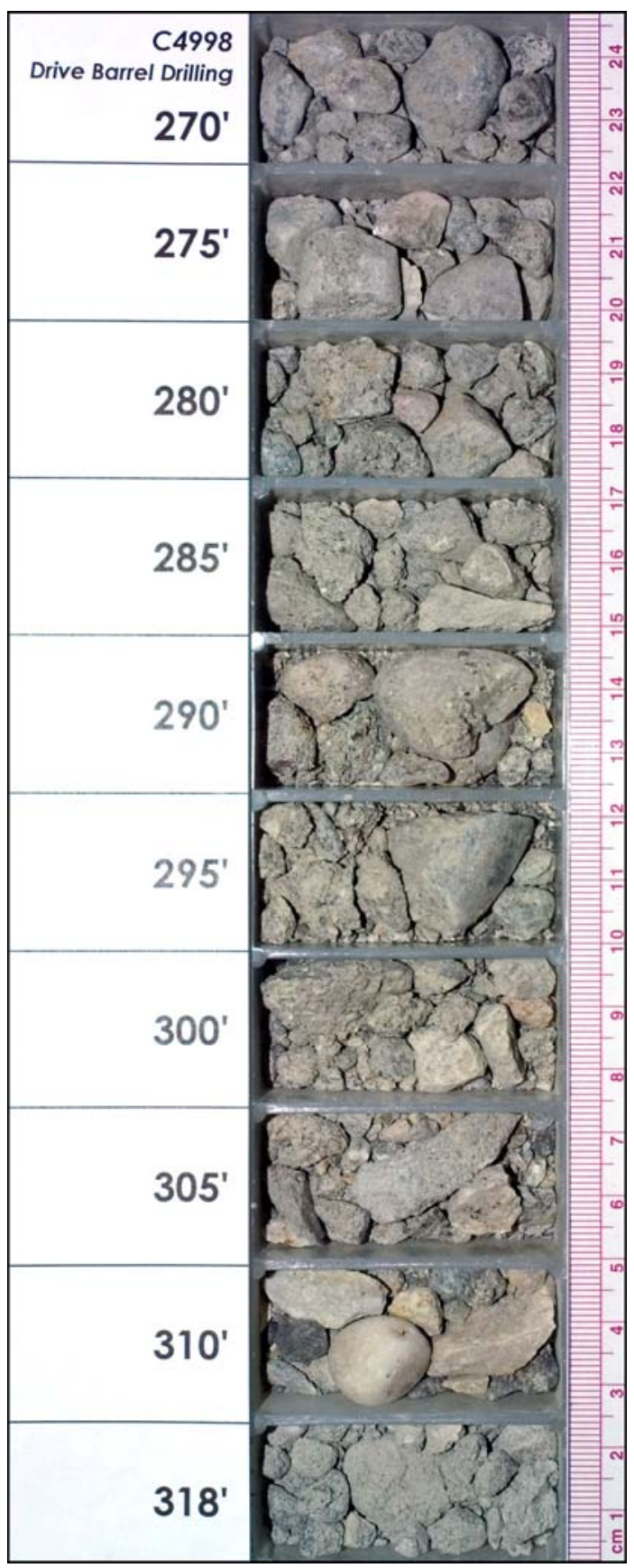

Figure 3.5. Example of Drill Cuttings from the Cold Creek Unit from the C4998 Entry Borehole. Moderately sorted sandy gravel composed of a heterolithic mixture of clasts. Note predominantly gray color and lack of weathering rinds or rusty stain characteristic of the underlying Ringold Unit A. Relatively high number of angular clasts in this tray were probably generated by crushing inside the drive barrel. 


\subsubsection{Hanford Formation}

The Hanford formation (informal name) at the WTP is subdivided into two units. The H2 unit is sand-dominated, whereas the $\mathrm{H} 3$ unit consists of predominantly clast-supported gravel. Both units are the result of repeated cataclysmic Ice Age floods that allowed up to $300 \mathrm{ft}$ of sediment to deposit onto the huge Cold Creek flood bar within the west-central Hanford Site during the Pleistocene (DOE 1988; DOE-RL 2002; Bjornstad 2006).

\subsubsection{H3 Unit}

The gravel-dominated H3 unit of the Hanford formation consists of loose, poorly sorted mixtures of gravel, sand, and silt. Gravel clasts in flood gravels generally consist of $50 \%$ to $75 \%$ or more basalt (Figure 3.6). Coarser deposits within this unit range from clast-supported, pebble to boulder gravel to matrix-supported pebbly sand. This unit ranges from 70 to $91 \mathrm{ft}$ thick beneath the WTP (Table 3.2, Figure 3.2). The deposits are weakly to strongly calcareous.

The basalt gravel clasts are usually subangular to subrounded because of relatively recent erosion, transport, and rapid burial of locally derived basaltic detritus during Pleistocene flooding. Gravel clasts of other compositions (quartzite, granite, gneiss, and volcaniclastics) are commonly more rounded as a result of reworking by the floods of older fluvial deposits (e.g., Ringold and Ellensburg formations). Individual beds of gravel-dominated facies several meters or more thick are common. Gravel-dominated lithofacies of the Hanford formation are distinguished from the Ringold Formation and coarse-grained fluvial facies of the Cold Creek unit by a greater percentage of basalt clasts, with less rounding and poorer sorting for the Hanford formation (DOE-RL 2002).

In outcrop, the gravel-dominated H3 unit of the Hanford formation consists of complexly stratified, horizontal to large-scale, planar-tabular cross-bedded and poorly sorted mixtures of gravel, sand, and silt (Figure 3.7). Clast-supported gravels within the H3 unit occasionally display an open-work fabric where no infilling matrix is present between clasts.

\subsubsection{H2 Unit}

The $\mathrm{H} 2$ unit is by far the thickest suprabasalt unit beneath the WTP, ranging from approximately 149 to $166 \mathrm{ft}$ thick beneath the WTP site (Table 3.2, Figure 3.2). The mineralogy of the sand fraction varies according to grain size. Coarser sand contains a greater percentage of dark basalt rock fragments, usually ranging from 50 to $90 \%$, giving the sediment a dark gray to black color and a distinctive salt-and-pepper appearance (Figure 3.8). Fine sand and silt beds, on the other hand, consist of mostly light-colored, ironstained quartz, feldspar and mica grains producing sediments that are light gray to pale brown. This unit is weakly to strongly calcareous, a weak paleosol at the top of some graded flood bed, indicating subaerial exposure between flood episodes.

In outcrop, the sand-dominated $\mathrm{H} 2$ unit consists of alternating graded beds, several or more feet thick, composed of moderately sorted medium- to coarse-grained sand, or matrix-supported pebbly sand, frequently grading upward or downward into well-sorted fine sand and silt (DOE-RL 2002). Ripple to horizontal laminations occur throughout (Figure 3.9). 


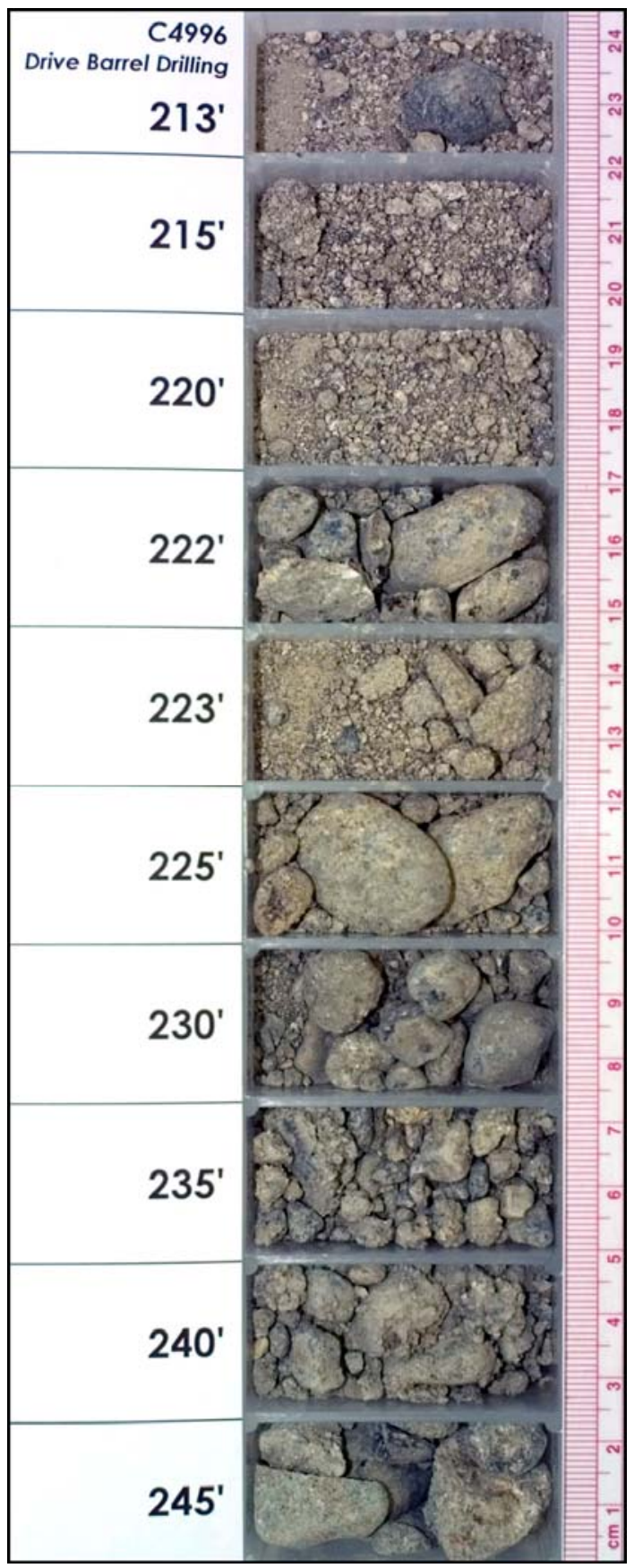

Figure 3.6. Example of Drill Cuttings from the Gravel-Dominated Hanford Formation (H3 Unit) from the C4996 Entry Borehole. Note high concentration of basalt rock fragments, gray color, poor sorting, and angularity of gravel $(>2 \mathrm{~mm})$ clasts, which are characteristic of this facies. Note: samples in tray represent mostly matrix material for the $\mathrm{H} 3$ unit. Larger clasts that did not fit into bins, which are the majority of clasts, were selectively excluded. 


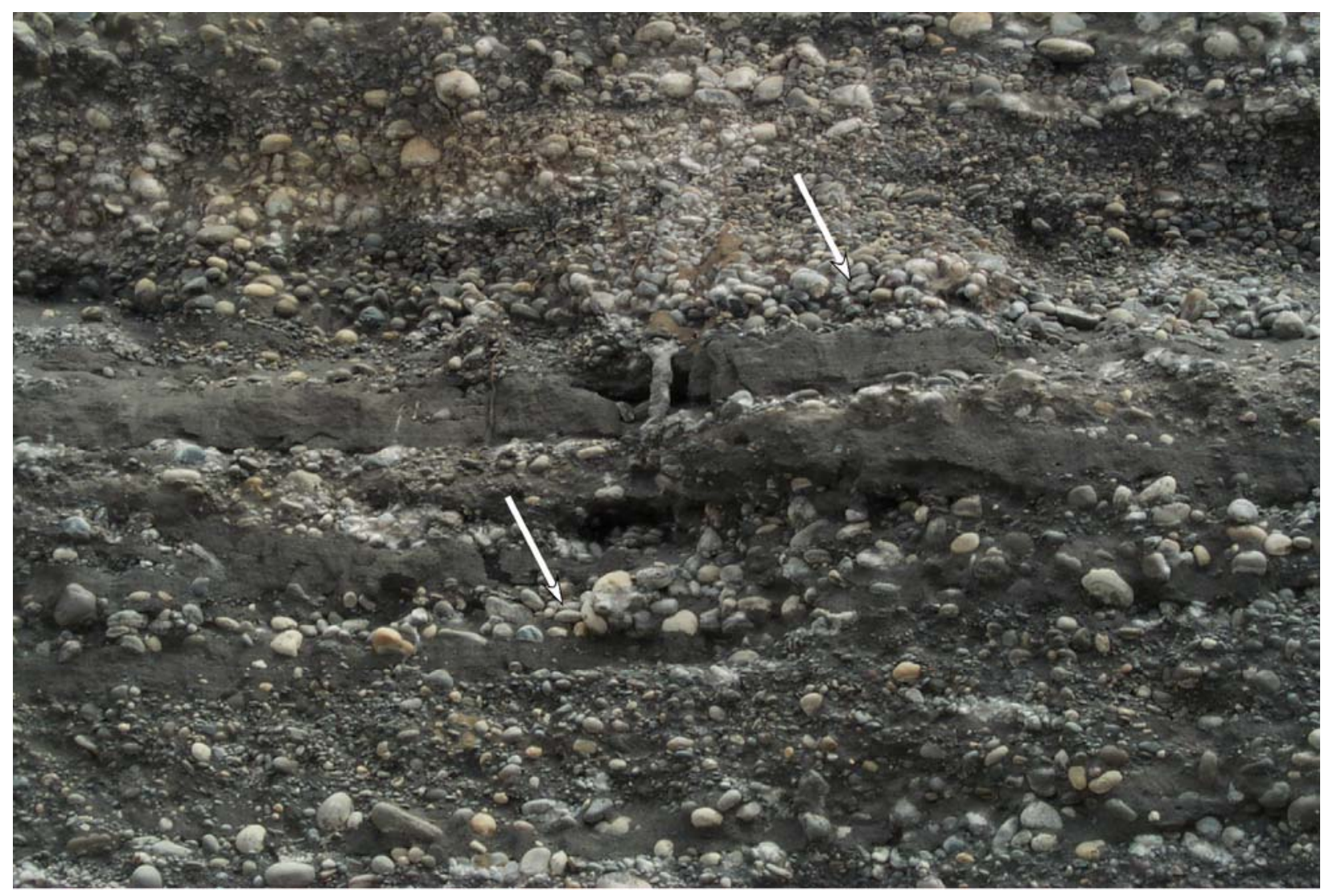

Figure 3.7. Example of Gravel-Dominated Hanford Formation from Borrow Pit in North Richland, Approximately 15 Miles Southeast of the Waste Treatment Plant. Note chaotic bedding of basalt-rich, clast-supported gravels interbedded with basaltic, matrix-supported, pebbly sands. Arrows point to areas with open-work fabric, a feature common to coarse-grained flood deposits of the Hanford formation. 


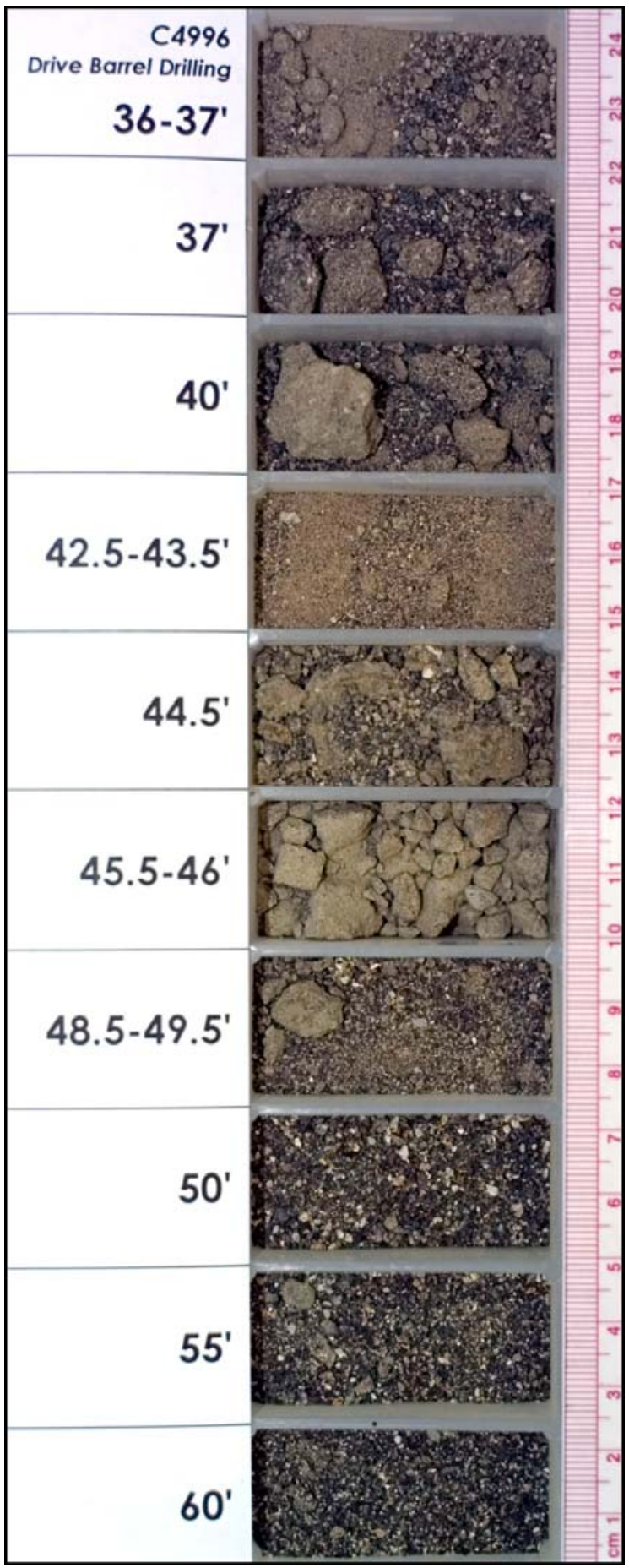

Figure 3.8. Example of Drill Cuttings from the Sand-Dominated Hanford Formation (Unit H2) from the C4996 Entry Borehole. Note multiple layers of pale-brown colored, well-sorted silty fine sand at 42.5 and $45.5 \mathrm{ft}$ bgs. These silty lenses may represent slackwater sedimentation that occurred between flood pulses similar to that shown in Figure 3.9. 


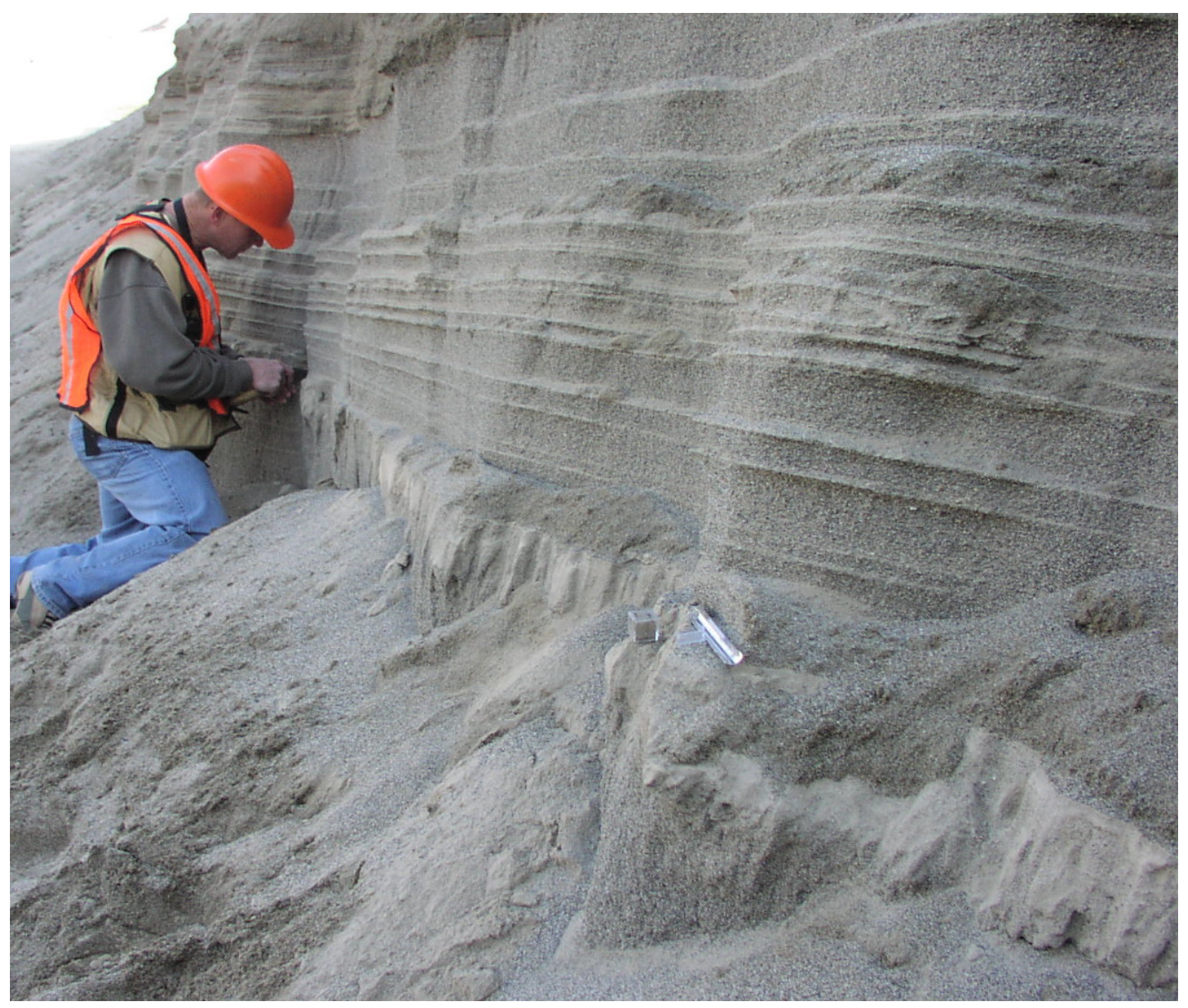

Figure 3.9. Sand-Dominated Facies of the Hanford Formation (H2 Unit) Within the Integrated Disposal Facility Excavation, Approximately 1 Mile Southwest of the Waste Treatment Plant. Sediments are predominantly horizontal to planar laminated, moderately sorted, pebbly, medium to coarse sand with lenses and laminae of finer-grained sand and silt. Silty fine sand bed being sampled may represent deposition during slackwater phase at end of a flood cycle. Comparable strata exist in the H2 unit beneath the WTP.

\subsubsection{Recent Deposits}

Recent deposits at the WTP include up to a few meters of man-made backfill material overlying or intermixed with eolian (i.e., windblown) sand, which disconformably overlie catatclysmic flood deposits of the Hanford formation. Recent deposits range from 0.3 to $16.8 \mathrm{ft}$ thick beneath the WTP (Table 3.2, Figure 3.2). Practically no recent deposits were encountered at entry borehole C4993 (0.3 ft) because this hole was drilled at the base of a previously excavated pit. Backfill material consists of mostly a compacted, poorly sorted, fine- to coarse-grained sand (Figure 3.10). The contact with the underlying cataclysmic flood deposits of the Hanford formation is recognized where the massive sands begin to show stratification at depth. 


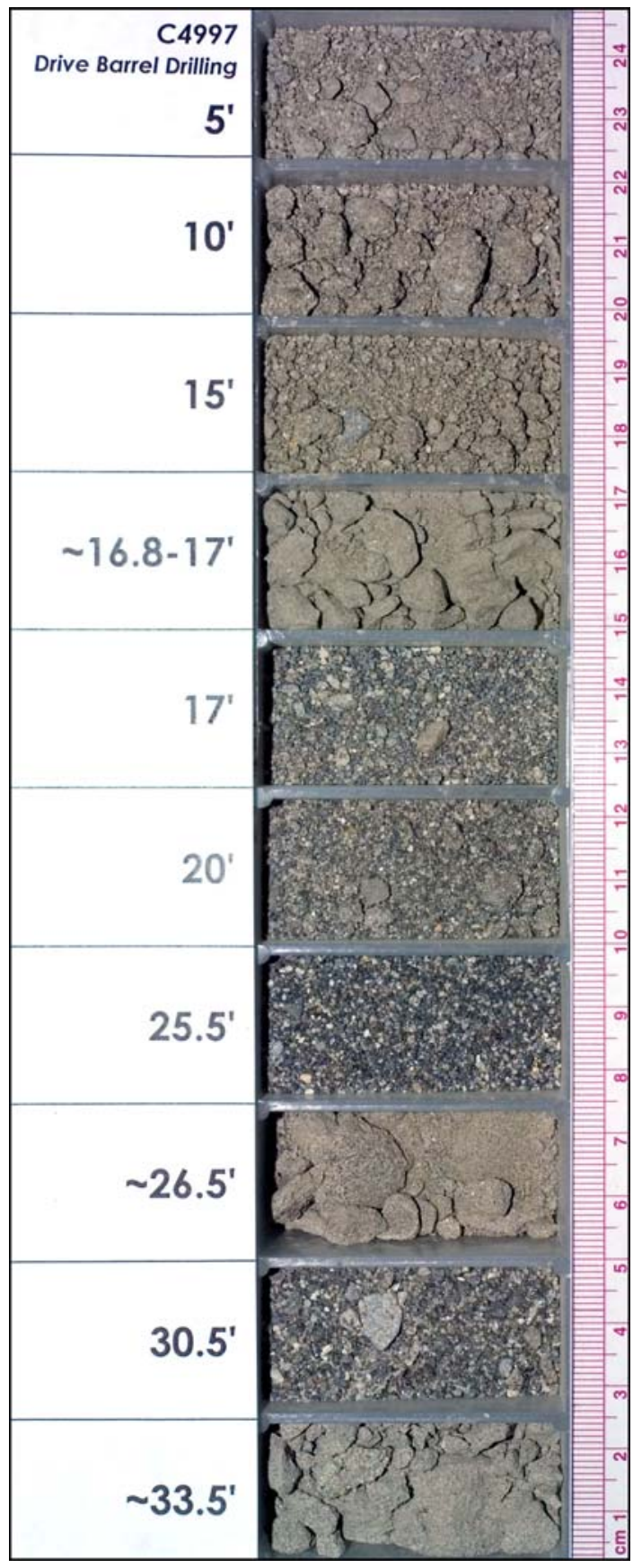

Figure 3.10. Example of Drill Cuttings from Recent Deposits and Upper Part of Hanford Formation H2 Unit from the C4997 Entry Borehole. Backfill material is present to approximately $16.8 \mathrm{ft}$ bgs. A thin (0.2-ft) layer of compacted fine sand probably represents slackwater flood sediment laid down at the end of Ice Age flooding. Below that are basaltic, salt-andpepper-like flood deposits of the Hanford formation $\mathrm{H} 2$ unit, with intervening slackwater beds at 26.5 and $33.5 \mathrm{ft}$ bgs. 


\subsection{Geology of Seismic Entry Boreholes}

The four entry boreholes (C4998, C4996, C4997, and C4993) are described in the order in which they were drilled.

\subsubsection{Entry Borehole C4998 - Geologic Interpretation}

A summary geologic log at C4998, which includes an interpretation of the suprabasalt sediments and unconfined aquifer, is presented in Figure 3.11. At this location, in situ sediments are overlain by a backfill layer of sand intermixed with eolian sand and silt, which extend from ground surface to a depth of about $9 \mathrm{ft}$ bgs. Sediment below the sand fill, from 9 to $159.5 \mathrm{ft} \mathrm{bgs}$, consists of sand-dominated Hanford formation Unit H2. The interval from 159.5 to $250 \mathrm{ft}$ bgs consists of gravel-dominated Hanford formation Unit H3. The Hanford formation overlies the Cold Creek unit, which extend from 250 to $322 \mathrm{ft}$ bgs. Sediments of the Ringold Formation Unit A were encountered between $322 \mathrm{ft}$ bgs to $382 \mathrm{ft}$ bgs. Basalt of the Elephant Mountain Member of the Columbia River Basalt Group was encountered from $382 \mathrm{ft}$ bgs to a total entry borehole depth of $401.5 \mathrm{ft}$ bgs.

Geophysical logs reveal additional information on the geology and borehole conditions at C4998 (Figure 3.11). The compensated-density log reveals a sharp increase in density at the contact between sand-dominated $\mathrm{H} 2$ and gravel-dominated $\mathrm{H} 3$ units of the Hanford formation. This corroborates an expected increase in density associated with higher proportions of solid pebbles and cobbles relative to porous sand. At the same time, sudden decreases in density most likely represent voids around the casing, created by caving or overdrilling the formation during drilling. Narrow voids around the casing occurred near the bottom of the Hanford formation $\mathrm{H} 2$ unit at approximately $150 \mathrm{ft}$ bgs and within the Cold Creek unit at approximately $270 \mathrm{ft}$ bgs. A relatively thick zone of low density occurred at the top of Ringold Unit A in C4998, where the drill rate slowed significantly and the formation appeared to be consolidated. Therefore, it seems likely this void may have formed from overdrilling and reaming of the hole that occurred while trying to advance through the difficult zone. There is an apparent decrease in natural gamma-ray activity within Ringold Unit A. The explanation for this is unclear but may be related to many millions of years of leaching of natural radioactivity (i.e., potassium-40) out of the formation by groundwater.

\subsubsection{Entry Borehole C4996 - Geologic Interpretation}

A summary geologic log at C4996, which includes an interpretation of the suprabasalt sediments and unconfined aquifer, is presented in Figure 3.12. At this location, in situ sediments are overlain by a backfill layer of crushed gravel intermixed with eolian sand and silt, which extend from ground surface to a depth of $4.5 \mathrm{ft}$ bgs. Sediment below the recent deposits, from 4.5 to $165.5 \mathrm{ft}$ bgs consists of sand-dominated Hanford formation $\mathrm{H} 2$ unit. The interval from 165.5 to $255 \mathrm{ft}$ bgs consists of gravel-dominated Hanford formation $\mathrm{H} 3$ unit. The gravel-dominated $\mathrm{H} 3$ sequence at this site includes several intermittent sand-dominated layers as well. The contact with the Cold Creek unit was chosen based on the sharp decrease in basalt content at $255 \mathrm{ft}$ bgs. At $304 \mathrm{ft} \mathrm{bgs,} \mathrm{a} \mathrm{color} \mathrm{change} \mathrm{and} \mathrm{more}$ difficult drilling conditions signify the contact with Unit A of the Ringold Formation at this depth. Basalt of the Elephant Mountain Member of the Columbia River Basalt Group was encountered from $349 \mathrm{ft}$ bgs to a total entry-borehole depth of $369 \mathrm{ft}$ bgs. 


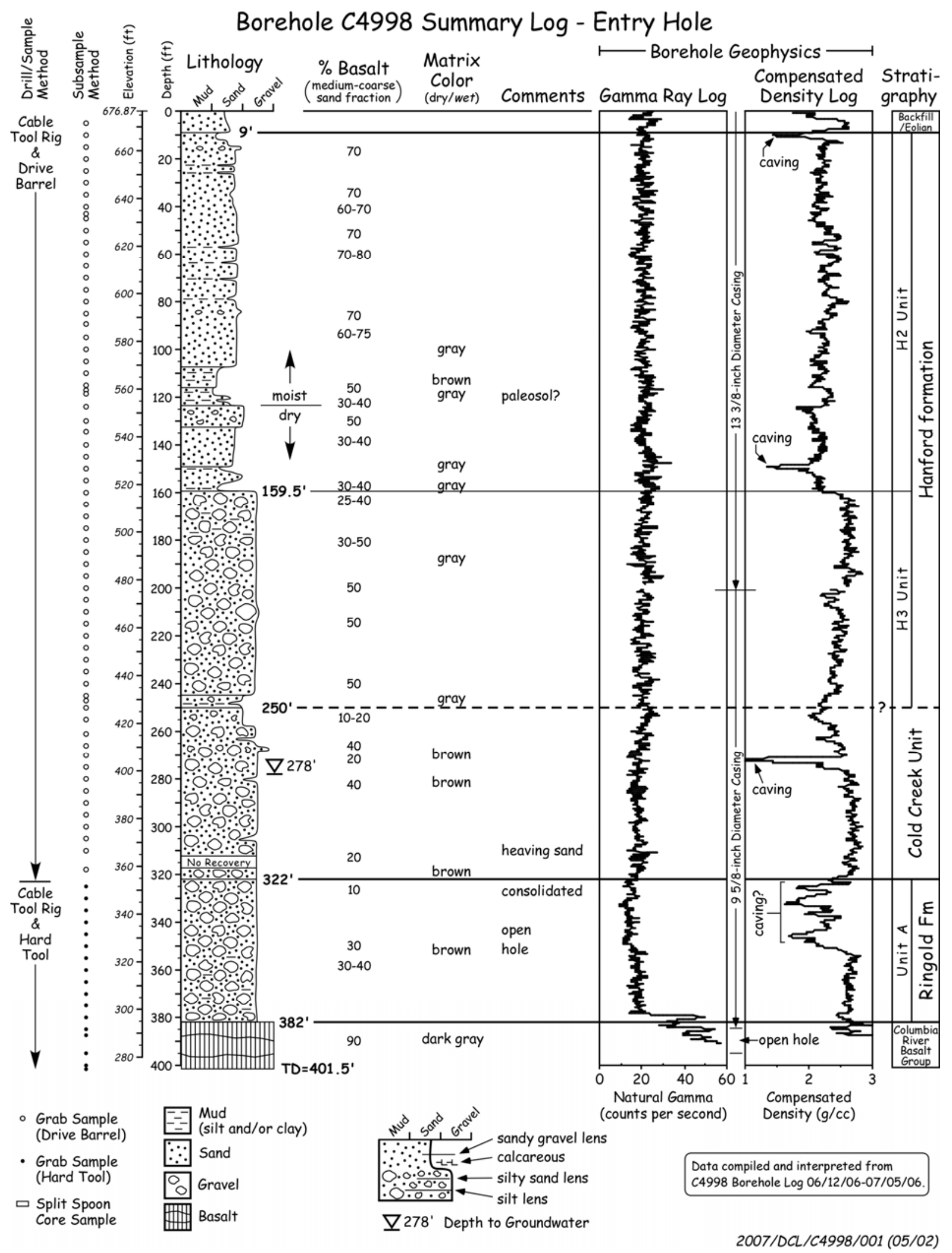

Figure 3.11. Composite Borehole Geophysical Logs for Seismic Entry Borehole C4998. Note: only surveys logged through single-cased intervals were used to create this composite. 


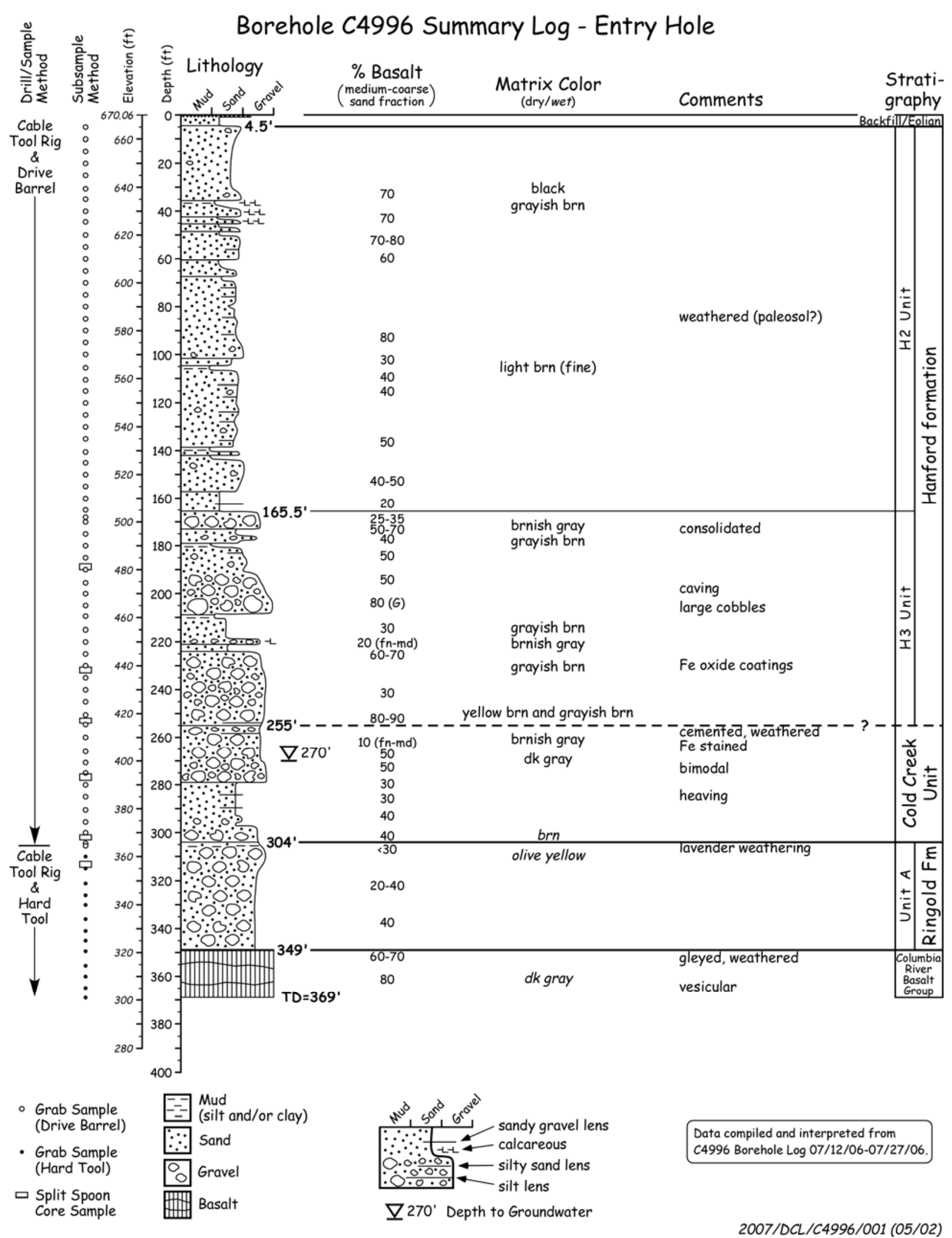

Figure 3.12. Summary Geologic Log for the C4996 Entry Borehole 


\subsubsection{Entry Borehole C4997 - Geologic Interpretation}

A summary geologic $\log$ at C4997, which includes an interpretation of the suprabasalt sediments and unconfined aquifer, is presented in Figure 3.13. At this location, in situ sediments are overlain by a backfill layer of sand intermixed with eolian sand and silt, which extend from ground surface to a depth of about $16.8 \mathrm{ft}$ bgs. Sediment below the sand fill, from 16.8 to $166 \mathrm{ft}$ bgs consists of Unit H2 sanddominated sediment of the Hanford formation. The interval from 166 to $255.5 \mathrm{ft}$ bgs contains Unit H3 gravel-dominated sediment of the Hanford formation. The Hanford formation overlies the Cold Creek unit, which extends from 255.5 to $319 \mathrm{ft}$ bgs. Sediments of the Ringold Formation Unit A were encountered between $319 \mathrm{ft}$ bgs to $383 \mathrm{ft}$ bgs. Basalt of the Elephant Mountain Member of the Columbia River Basalt Group was encountered from $383 \mathrm{ft}$ bgs to a total entry-borehole depth of $401 \mathrm{ft}$ bgs.

The number of blows required to drive the split spoon sampler reveals information on the grain size and degree of consolidation of the sediments being drilled (Figure 3.13). Because of finer grain size and looser consistency of the sand-dominated Hanford formation $\mathrm{H} 2$ unit, it is relatively easy to core. The gravel-dominated Hanford formation $\mathrm{H} 3$ unit, on the other hand, required the most blows to drive the sampler, perhaps due to the higher concentration of larger gravel clasts, which tend to plug the opening of the split spoon. This is suggested in Figure 3.13 by a series of split-spoons collected at the top of the $\mathrm{H} 3$ unit (170-200 ft bgs) that went unfilled when the sampler encountered cobbles or boulders of larger diameter than the split spoon ( $>4$ in.) that could not be penetrated. Hardness of the Cold Creek unit is variable, especially across a sandy zone between 280 and $290 \mathrm{ft}$ bgs. The greatest number of blows (680) was required to drive the sampler the full $2.5 \mathrm{ft}$ into Ringold Unit A.

\subsubsection{Entry Borehole C4993 - Geologic Interpretation}

A summary geohydrologic $\log$ at $\mathrm{C} 4993$, which includes an interpretation of the suprabasalt sediments and unconfined aquifer, is presented in Figure 3.14. At this location, in situ sediments are overlain by a backfill layer of crushed gravel intermixed with eolian sand and silt, which extend from ground surface to a depth of about $0.3 \mathrm{ft}$ bgs. Sediment below the backfill, from 0.3 to $166 \mathrm{ft}$ bgs belongs to the sand-dominated Hanford formation $\mathrm{H} 2$ unit. The interval from 166 to $236 \mathrm{ft}$ bgs includes graveldominated Hanford formation $\mathrm{H} 3$ unit. The Hanford formation overlies the Cold Creek unit (consisting mostly of reworked Ringold Formation sediments), which extends from 236 to $290 \mathrm{ft}$ bgs. Gravelly sediments of the Ringold Formation Unit A were encountered between 290 and $358 \mathrm{ft} \mathrm{bgs.} \mathrm{Basalt} \mathrm{of} \mathrm{the}$ Elephant Mountain Member of the Columbia River Basalt Group was encountered from $358 \mathrm{ft}$ bgs to a total entry-borehole depth of $383.5 \mathrm{ft}$ bgs. 


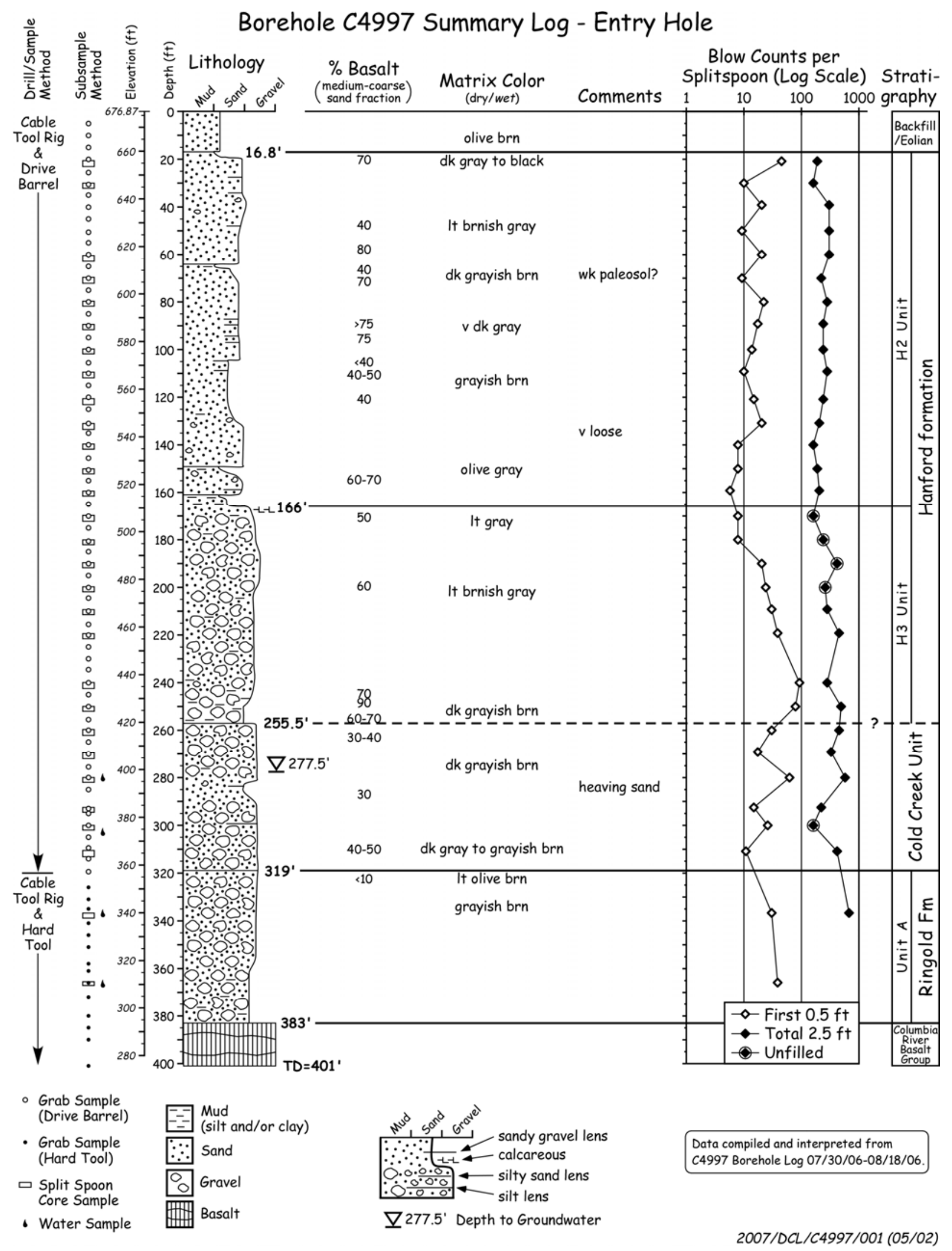

Figure 3.13. Summary Geologic Log for the C4997 Entry Borehole 


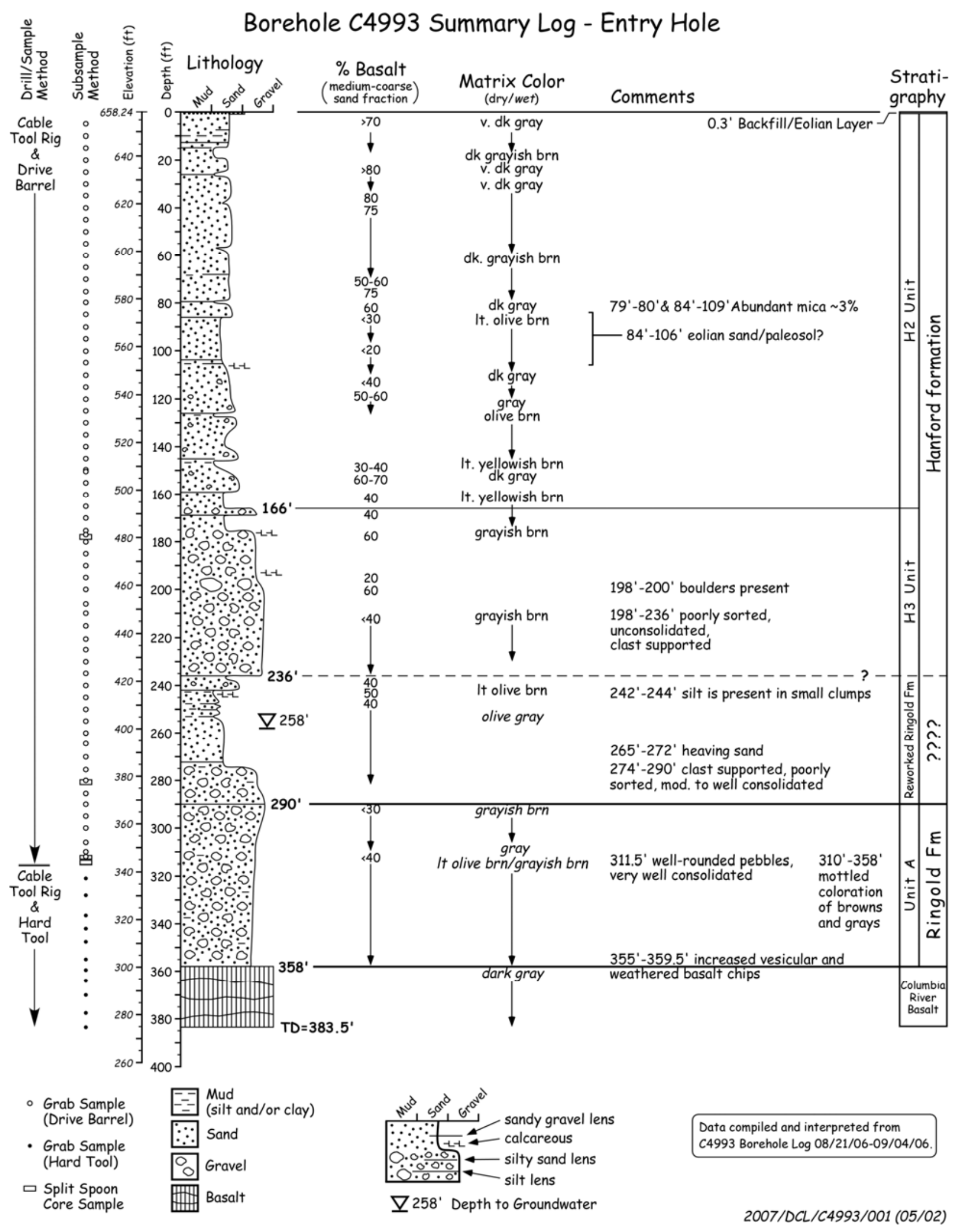

Figure 3.14. Summary Geologic Log for the C4993 Entry Borehole 


\subsection{Columbia River Basalt at the Waste Treatment Plant}

The main geology units of interest at the WTP are the Saddle Mountains Basalt and the interbedded sediments of the Ellensburg Formation. The seismic boreholes at the WTP penetrated the upper part of the Wanapum Basalt and provide information on the upper Wanapum Basalt and a local sedimentary interbed, the Byron Interbed. Borehole C4996 was the deepest borehole, reaching the upper part of the Roza Member, Wanapum Basalt.

The depth and thickness of the flows penetrated at the WTP are given in Table 4.1. Table 4.2 provides the contacts and intraflow structure depths for core hole C4998. Table 4.3 provides the contacts and intraflow structure depths for the mud-rotary boreholes (i.e., C4993, C4996, and C4997). Table 4.4 provides the contacts and thicknesses for the Ellensburg Formation sedimentary interbeds. The depths in the mud-rotary holes are based on using geophysical logs in combination with the well-site geologists' logs. Tables 4.1 through 4.4 should be used as the best interpretations of the contacts for the CRBG and Ellensburg Formation units at the WTP site.

Table 4.1. Elevation and Thickness of Columbia River Basalt Group and Ellensburg Formation Units Penetrated by the Waste Treatment Plant Seismic Boreholes. Elevations are in feet above/below mean sea level. Thicknesses are in feet, rounded to the nearest foot. Metric numbers are given in parentheses.

\begin{tabular}{|c|c|c|c|c|c|}
\hline & & C4993 & C4996 & C4997 & C4998 \\
\hline Stratigraphic Unit & Surface Elevation & $\begin{array}{l}658.24 \\
(200.6)\end{array}$ & $\begin{array}{l}670.06 \\
(204.2)\end{array}$ & $\begin{array}{l}676.87 \\
(206.3)\end{array}$ & $\begin{array}{l}676.87 \\
(206.3)\end{array}$ \\
\hline \multirow[t]{2}{*}{$\begin{array}{l}\text { Top of Elephant } \\
\text { Mountain Member }\end{array}$} & $\begin{array}{l}\text { Elevation of Upper } \\
\text { Contact }\end{array}$ & $\begin{array}{l}300.2 \\
(91.5) \\
\end{array}$ & $\begin{array}{l}321.1 \\
(97.9) \\
\end{array}$ & $\begin{array}{l}293.9 \\
(89.6) \\
\end{array}$ & $\begin{array}{l}294.9 \\
(89.9) \\
\end{array}$ \\
\hline & Thickness & $\begin{array}{l}118 \text { Eroded } \\
(36.0)\end{array}$ & $\begin{array}{l}104 \text { Eroded } \\
(31.7)\end{array}$ & $\begin{array}{l}112 \text { Eroded } \\
(34.1)\end{array}$ & $\begin{array}{l}110 \text { Eroded } \\
(33.5)\end{array}$ \\
\hline \multirow[t]{2}{*}{$\begin{array}{l}\text { Rattlesnake Ridge } \\
\text { Interbed }\end{array}$} & $\begin{array}{l}\text { Elevation of Upper } \\
\text { Contact }\end{array}$ & $\begin{array}{l}182.2 \\
(55.5) \\
\end{array}$ & $\begin{array}{l}217.1 \\
(66.2) \\
\end{array}$ & $\begin{array}{l}181.9 \\
(55.4) \\
\end{array}$ & $\begin{array}{l}184.9 \\
(56.3) \\
\end{array}$ \\
\hline & Thickness & $\begin{array}{c}56 \\
(17.1) \\
\end{array}$ & $\begin{array}{c}42 \\
(12.8)\end{array}$ & $\begin{array}{c}47 \\
(14.3)\end{array}$ & $\begin{array}{c}34 \\
(10.2) \\
\end{array}$ \\
\hline \multirow[t]{2}{*}{ Pomona Member } & $\begin{array}{l}\text { Elevation of Upper } \\
\text { Contact }\end{array}$ & $\begin{array}{l}126.2 \\
(38.5)\end{array}$ & $\begin{array}{l}175.1 \\
(53.3)\end{array}$ & $\begin{array}{l}134.9 \\
(41.1)\end{array}$ & $\begin{array}{l}151.3 \\
(46.1)\end{array}$ \\
\hline & Thickness & $\begin{array}{c}186 \\
(56.7) \\
\end{array}$ & $\begin{array}{c}201 \\
(61.3) \\
\end{array}$ & $\begin{array}{c}196 \\
(59.7) \\
\end{array}$ & $\begin{array}{c}209 \\
(63.8) \\
\end{array}$ \\
\hline \multirow[t]{2}{*}{ Selah Member } & $\begin{array}{l}\text { Elevation of Upper } \\
\text { Contact }\end{array}$ & $\begin{array}{l}-59.8 \\
(-18.2)\end{array}$ & $\begin{array}{l}-26.5 \\
(-7.9)\end{array}$ & $\begin{array}{l}-61.1 \\
(-18.6)\end{array}$ & $\begin{array}{l}-58.1 \\
(-17.7)\end{array}$ \\
\hline & Thickness & $\begin{array}{c}23 \\
(7.0) \\
\end{array}$ & $\begin{array}{c}22 \\
(6.7) \\
\end{array}$ & $\begin{array}{c}22 \\
(6.7) \\
\end{array}$ & $\begin{array}{c}22 \\
(6.7) \\
\end{array}$ \\
\hline \multirow[t]{2}{*}{ Esquatzel Member } & $\begin{array}{l}\text { Elevation of Upper } \\
\text { Contact }\end{array}$ & $\begin{array}{l}-82.8 \\
(-25.2)\end{array}$ & $\begin{array}{l}-48.0 \\
(-14.6)\end{array}$ & $\begin{array}{l}-83.1 \\
(-25.3)\end{array}$ & $\begin{array}{l}-80.1 \\
(-24.4)\end{array}$ \\
\hline & Thickness & $\begin{array}{c}95 \\
(29.0) \\
\end{array}$ & $\begin{array}{c}96 \\
(29.3) \\
\end{array}$ & $\begin{array}{c}95 \\
(29.0) \\
\end{array}$ & $\begin{array}{c}94 \\
(28.7) \\
\end{array}$ \\
\hline \multirow[t]{2}{*}{$\begin{array}{l}\text { Cold Creek } \\
\text { Interbed }\end{array}$} & $\begin{array}{l}\text { Elevation of Upper } \\
\text { Contact }\end{array}$ & $\begin{array}{l}-177.8 \\
(-54.2) \\
\end{array}$ & $\begin{array}{l}-143.9 \\
(-43.9) \\
\end{array}$ & $\begin{array}{l}-178.1 \\
(-54.3)\end{array}$ & $\begin{array}{l}-174.1 \\
(-53.1)\end{array}$ \\
\hline & Thickness & $\begin{array}{c}97 \\
(29.6)\end{array}$ & $\begin{array}{c}98 \\
(29.9)\end{array}$ & $\begin{array}{c}98 \\
(29.9)\end{array}$ & $\begin{array}{c}98 \\
(29.9)\end{array}$ \\
\hline
\end{tabular}


Table 4.1. (contd)

\begin{tabular}{|c|c|c|c|c|c|}
\hline & & $\mathrm{C} 4993$ & C4996 & C4997 & $\begin{array}{l}\mathrm{C} 4998 \\
\end{array}$ \\
\hline \multirow[t]{2}{*}{ Umatilla Member } & $\begin{array}{l}\text { Elevation of Upper } \\
\text { Contact }\end{array}$ & $\begin{array}{l}-274.8 \\
(-83.7)\end{array}$ & $\begin{array}{l}-241.9 \\
(-73.7)\end{array}$ & $\begin{array}{l}-276.1 \\
(-84.2)\end{array}$ & $\begin{array}{l}-272.1 \\
(-82.9)\end{array}$ \\
\hline & Thickness & $\begin{array}{c}161 \\
(49.1)\end{array}$ & $\begin{array}{c}149 \\
(45.4)\end{array}$ & $\begin{array}{c}161 \\
(49.1)\end{array}$ & $\begin{array}{c}157 \\
(47.9)\end{array}$ \\
\hline \multirow[t]{2}{*}{ Mabton Interbed } & $\begin{array}{l}\text { Elevation of Upper } \\
\text { Contact }\end{array}$ & $\begin{array}{l}-435.8 \\
(-132.8) \\
\end{array}$ & $\begin{array}{l}-390.0 \\
(-119.2) \\
\end{array}$ & $\begin{array}{c}-437.1 \\
(-133.0) \\
\end{array}$ & $\begin{array}{c}-429.1 \\
(-130.8) \\
\end{array}$ \\
\hline & Thickness & $\begin{array}{c}98 \\
(29.9) \\
\end{array}$ & $\begin{array}{c}101 \\
(30.8)\end{array}$ & $\begin{array}{c}94 \\
(28.7) \\
\end{array}$ & $\begin{array}{c}98 \\
(29.9) \\
\end{array}$ \\
\hline \multirow{2}{*}{$\begin{array}{l}\text { Priest Rapids } \\
\text { Member, Lolo } \\
\text { Flow }\end{array}$} & $\begin{array}{l}\text { Elevation of Upper } \\
\text { Contact }\end{array}$ & $\begin{array}{c}-533.8 \\
(-162.7) \\
\end{array}$ & $\begin{array}{c}-491.9 \\
(-149.9) \\
\end{array}$ & $\begin{array}{c}-531.1 \\
(-161.9) \\
\end{array}$ & $\begin{array}{c}-527.1 \\
(-160.7) \\
\end{array}$ \\
\hline & Thickness & $\begin{array}{c}161 \\
(49.1) \\
\end{array}$ & $\begin{array}{c}160 \\
(48.8) \\
\end{array}$ & $\begin{array}{c}156 \\
(47.6) \\
\end{array}$ & $\begin{array}{c}161 \\
(49.1) \\
\end{array}$ \\
\hline \multirow[t]{2}{*}{ Byron Interbed } & $\begin{array}{l}\text { Elevation of Upper } \\
\text { Contact }\end{array}$ & ND & $\begin{array}{l}-651.9 \\
(-198.7)\end{array}$ & ND & ND \\
\hline & Thickness & 0 & $\begin{array}{c}5 \\
(1.5) \\
\end{array}$ & 0 & 0 \\
\hline \multirow{2}{*}{$\begin{array}{l}\text { Priest Rapids } \\
\text { Member, Rosalia } \\
\text { Flow }\end{array}$} & $\begin{array}{l}\text { Elevation of Upper } \\
\text { Contact }\end{array}$ & $\begin{array}{l}-694.8 \\
(-211.8)\end{array}$ & $\begin{array}{l}-656.9 \\
(-200.2)\end{array}$ & $\begin{array}{l}-687.1 \\
(-209.4)\end{array}$ & $\begin{array}{l}-688.0 \\
(-209.7)\end{array}$ \\
\hline & Thickness & ND & $\begin{array}{c}56 \\
(18.6)\end{array}$ & ND & ND \\
\hline \multirow[t]{2}{*}{ Roza Member } & $\begin{array}{l}\text { Elevation of Upper } \\
\text { Contact }\end{array}$ & ND & $\begin{array}{c}-712.9 \\
(-217.3) \\
\end{array}$ & ND & ND \\
\hline & Thickness & ND & ND & ND & ND \\
\hline
\end{tabular}

Table 4.2. Depths of Contacts and Intraflow Structures for C4998. Ranges are upper and lower contact.

\begin{tabular}{|c|c|c|c|c|c|c|}
\hline & $\begin{array}{l}\text { Priest Rapids } \\
\text { Member, } \\
\text { Rosalia } \\
\end{array}$ & $\begin{array}{l}\text { Priest Rapids } \\
\text { Member, Lolo }\end{array}$ & $\begin{array}{l}\text { Umatilla } \\
\text { Member }\end{array}$ & $\begin{array}{l}\text { Esquatzel } \\
\text { Member }\end{array}$ & $\begin{array}{l}\text { Pomona } \\
\text { Member }\end{array}$ & $\begin{array}{c}\text { Elephant } \\
\text { Mountain } \\
\text { Member }\end{array}$ \\
\hline Flow Top & 1365 & 1204 & 949-955 & $757-765$ & $526-590$ & Eroded 382 \\
\hline Vesicles & $1365-1387$ & $1207-1240$ & $\begin{array}{c}954-965 \\
1020-1025 \\
1035-1040 \\
1055-1065 \\
1100-1106 \\
\end{array}$ & $757-782$ & $\begin{array}{l}526-615 \\
685-690\end{array}$ & $\begin{array}{l}401-416 \\
469-492\end{array}$ \\
\hline $\begin{array}{l}\text { Breccia } \\
\text { Zones }\end{array}$ & ND & 1207 & $\begin{array}{c}949-955 \\
1040-1053\end{array}$ & $757-769$ & $\begin{array}{c}526-590 \\
710\end{array}$ & ND \\
\hline $\begin{array}{l}\text { Fractures and } \\
\text { Fracture } \\
\text { Zones }\end{array}$ & $1383-1387$ & $\begin{array}{l}1225-1230 \\
1300-1305 \\
1320-1325 \\
1358-1365\end{array}$ & $\begin{array}{c}970-973 \\
1015-1020 \\
1061-1065 \\
1070-1075 \\
1085-1095 \\
\end{array}$ & $815-825$ & $\begin{array}{l}550-565 \\
620-645 \\
660-675 \\
690-695 \\
710-725 \\
\end{array}$ & $\begin{array}{l}425-445 \\
480-485\end{array}$ \\
\hline Flow Bottom & ND & 1365 & 1106 & 851 & 735 & 492 \\
\hline Thickness & ND & 161 & 157 & 94 & 209 & 110 Eroded \\
\hline
\end{tabular}


Table 4.3. Depths to Basalt Contacts and Intraflow Structures for Mud-Rotary Boreholes. Ranges are upper and lower contact.

\begin{tabular}{|c|c|c|c|c|c|c|c|}
\hline & & $\begin{array}{c}\text { Priest Rapids } \\
\text { Member, } \\
\text { Rosalia }\end{array}$ & $\begin{array}{l}\text { Priest Rapids } \\
\text { Member, Lolo }\end{array}$ & $\begin{array}{l}\text { Umatilla } \\
\text { Member }\end{array}$ & $\begin{array}{l}\text { Esquatzel } \\
\text { Member }\end{array}$ & $\begin{array}{l}\text { Pomona } \\
\text { Member }\end{array}$ & $\begin{array}{c}\text { Elephant } \\
\text { Mountain } \\
\text { Member }\end{array}$ \\
\hline \multirow[t]{5}{*}{ C4993 } & Flow Top & $1353-1378$ & $1192-1195$ & $933-944$ & $741-760$ & $\begin{array}{c}\text { Breccia } \\
532-570\end{array}$ & Eroded 358-390 \\
\hline & Vesicles & ND & $\begin{array}{l}1225-1234 \\
1241-1299 \\
1288-1299\end{array}$ & ND & ND & ND & ND \\
\hline & $\begin{array}{l}\text { Breccia or } \\
\text { Fracture Zone }\end{array}$ & ND & ND & $\begin{array}{c}\text { Breccia } \\
975-987\end{array}$ & ND & ND & $\begin{array}{c}\text { Fractures } 435, \\
453\end{array}$ \\
\hline & Flow Bottom & ND & 1353 & 1094 & 836 & 718 & 476 \\
\hline & Thickness & ND & 161 & 161 & 95 & 186 & 118 \\
\hline \multirow[t]{5}{*}{ C4996 } & Flow Top & $1327-1340$ & $1162-1210$ & $912-962$ & $718-760$ & $\begin{array}{c}\text { Breccia } \\
495-595\end{array}$ & Eroded 349-384 \\
\hline & Vesicles & ND & ND & ND & ND & 630,682 & $405-415$ \\
\hline & Breccia Zone & ND & ND & $972-1010$ & ND & ND & ND \\
\hline & Flow Bottom & 1383 & 1322 & 1061 & 814 & 696 & 453 \\
\hline & Thickness & 56 & 160 & 149 & 96 & 201 & 104 \\
\hline \multirow[t]{5}{*}{ C4997 } & Flow Top & $1364-1370$ & $1208-1230$ & $953-962$ & $760-770$ & $\begin{array}{c}\text { Breccia } \\
542\end{array}$ & Eroded 383 \\
\hline & Vesicles & $1422-1424$ & $1226-1230$ & ND & ND & $615 ?$ & ND \\
\hline & $\begin{array}{l}\text { Breccia or } \\
\text { Fracture Zone }\end{array}$ & ND & ND & $\begin{array}{c}\text { Breccia } \\
1004-1026\end{array}$ & ND & ND & $\begin{array}{c}\text { Fractures } \\
396-400 \\
408-410 \\
\end{array}$ \\
\hline & Flow Bottom & ND & 1364 & 1114 & 855 & 738 & 495 \\
\hline & Thickness & ND & 156 & 161 & 95 & 196 & 112 \\
\hline
\end{tabular}

Table 4.4. Depth to Contacts and Thicknesses of Ellensburg Formation Sedimentary Interbeds

\begin{tabular}{|c|c|c|c|c|c|c|c|c|c|}
\hline & & \multicolumn{2}{|c|}{ Mabton } & \multicolumn{2}{|c|}{ Cold Creek } & \multicolumn{2}{|c|}{ Selah } & \multicolumn{2}{|c|}{ Rattlesnake Ridge } \\
\hline & Log Type & Geology & Geophysics & Geology & Geophysics & Geology & Geophysics & Geology & Geophysics \\
\hline \multirow[t]{3}{*}{$\mathrm{C} 4993$} & Top & 1095 & 1094 & 843 & 836 & 724 & 718 & 474 & 476 \\
\hline & Bottom & 1191 & 1192 & 935 & 933 & 742 & 741 & 532 & 532 \\
\hline & Thick & 96 & 98 & 92 & 97 & 18 & 23 & 58 & 56 \\
\hline \multirow[t]{3}{*}{ C4996 } & Top & 1067 & 1061 & 814 & 814 & 700 & 696 & 447 & 453 \\
\hline & Bottom & 1168 & 1162 & 911 & 912 & 720 & 718 & 495 & 495 \\
\hline & \begin{tabular}{|l|} 
Thick \\
\end{tabular} & 101 & 101 & 97 & 98 & 20 & 22 & 48 & 42 \\
\hline \multirow[t]{3}{*}{ C4997 } & Top & 1100 & 1114 & 855 & 855 & 737 & 738 & 495 & 495 \\
\hline & Bottom & 1205 & 1208 & 950 & 953 & 760 & 760 & 537 & 542 \\
\hline & Thick & 105 & 94 & 95 & 98 & 23 & 22 & 42 & 47 \\
\hline \multirow[t]{3}{*}{ C4998 } & Top & 1106 & ND & 851 & ND & 735 & ND & 492 & ND \\
\hline & Bottom & 1204 & ND & 949 & ND & 757 & ND & 526 & ND \\
\hline & \begin{tabular}{|l|} 
Thick \\
\end{tabular} & 98 & ND & 98 & ND & 22 & ND & 34 & ND \\
\hline
\end{tabular}




\subsection{Wanapum Basalt}

The Wanapum Basalt underlies the Saddle Mountains Basalt and represents a period of time from about 15.5 Ma to 14.5 Ma. The Wanapum Basalt consists of four members. Only the youngest two, the Roza and Priest Rapids Members, were penetrated at the WTP site by the seismic boreholes. The characteristic feature of theses flows is their high $\mathrm{TiO}_{2}$ and $\mathrm{FeO}$ compositions compared to the other lava flows of the CRBG.

\subsection{Roza Member}

The oldest Columbia River Basalt Group flow penetrated at the WTP by the seismic boreholes is the Roza Member. This flow typically is recognized by the presence of plagioclase phenocrysts. The Roza Member was erupted during a transitional magnetic polarity interval. These plagioclase phenocrysts and the transitional polarity are useful criteria that aid in the identification of this lava flow in the field. At the WTP only the upper part of the Roza Member flow was penetrated.

\subsection{Priest Rapids Member}

The Priest Rapids Member consists of two lava flows, the younger Lolo flow and the older Rosalia flow. The top of the Rosalia flow was the target depth for the seismic boreholes because a thin, irregular sedimentary interbed, the Byron Interbed, has been penetrated at several locations within the Hanford Site between the Lolo and Rosalia flows (DOE 1988). The Priest Rapids Member was erupted during a reversed magnetic polarity; the reversed polarity is used to identify it in the field as well as in cored samples. Both the Lolo and Rosalia flows of the Priest Rapids Member are typically coarser than most lava flows of the CRBG. Occasionally very coarse zones called pegmatoids are recognized in hand samples. The most distinguishing characteristic of the Priest Rapids Member is the chemical composition. Both the Lolo flow and the Rosalia flow can be readily identified using their chemical compositions (Table A.1 and Table B.1). At the WTP, the Lolo flow ranges from 156 to $161 \mathrm{ft}$ thick.

In borehole C4993, several sedimentary layers occur within the Lolo flow. These occur at the following depths below ground surface: $1225-1234 \mathrm{ft}(373.4-376.1 \mathrm{~m}), 1241-1249 \mathrm{ft}$ (378.3-380.7 m), and 1288-1299 ft (392.6-395.9 m), and correspond to the vesicular horizons shown in Table 4.3 (Rust et al. 2007).

\subsection{Saddle Mountains Basalt}

The Saddle Mountains Basalt is the youngest formation of the Columbia River Basalt Group. Within the WTP area, only 4 of the 14 members that constitute the formation are found. They are, from oldest to youngest, Umatilla, Esquatzel, Pomona, and Elephant Mountain members (Figure 2.2). The Asotin and Wilbur Creek Members occur just north of the WTP but are not present at the facility site. The Saddle Mountains Basalt is separated from the Wanapum Basalt by the Mabton Interbed of the Ellensburg Formation. Each of the members of the Saddle Mountains Basalt in the Hanford Site is separated by an interbed belonging to the Ellensburg Formation. 


\subsubsection{Umatilla Member}

The Umatilla Member is the lowermost member of the Saddle Mountains Basalt. Within the Hanford

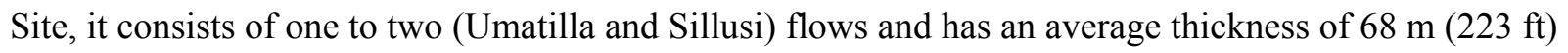
(Figure 4.1). The Umatilla Member consists of two eruptions of lava - the Umatilla flow and Sillusi flow-that are very closely spaced in time. Within the Hanford Site, the two flows mixed, producing one lava flow that cooled as a single one but with chemistry that is a mixture of both chemistries (Reidel 1998). At the WTP site, the flow is between 149 and $161 \mathrm{ft}$ thick. Brecciated basalt and sediment layers were encountered in the Umatilla Member in all boreholes. These breccias and sediments are contacts between lobes of the two lava flows of the Umatilla Member. The basalt of Sillusi is the younger upper flow in the boreholes.

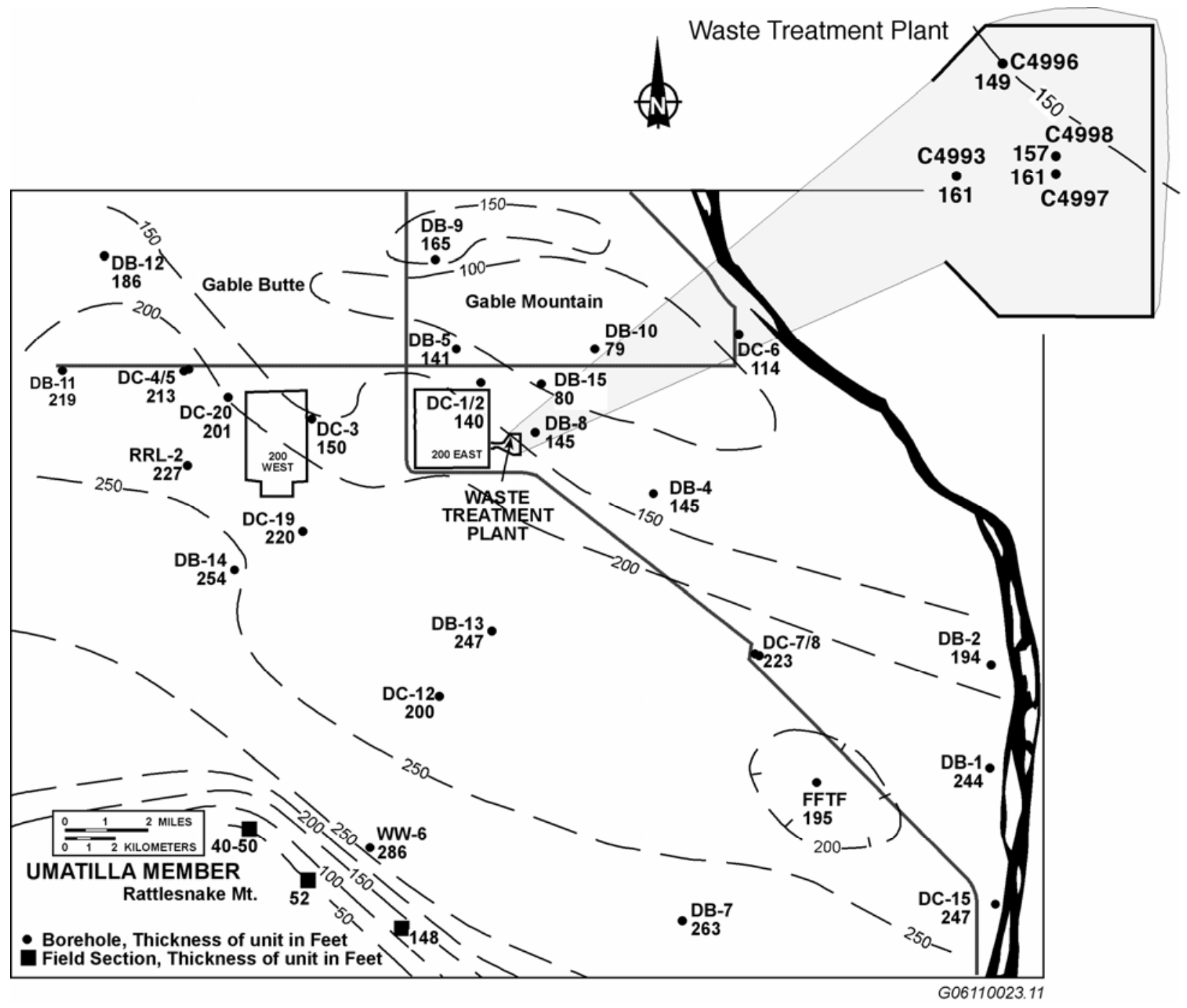

Figure 4.1. Umatilla Member Thickness on the Hanford Site and at the Waste Treatment Plant Site 


\subsubsection{Esquatzel Member}

The Esquatzel Member lies above the Umatilla Member and is separated from it by the Cold Creek Interbed of the Ellensburg Formation. The flow consists of one flow at the Hanford Site and has an average thickness of $32 \mathrm{~m}$ (105 ft) (Figure 4.2). At the WTP site, the flow has uniform thickness, varying only between 94 and $96 \mathrm{ft}$ thick.

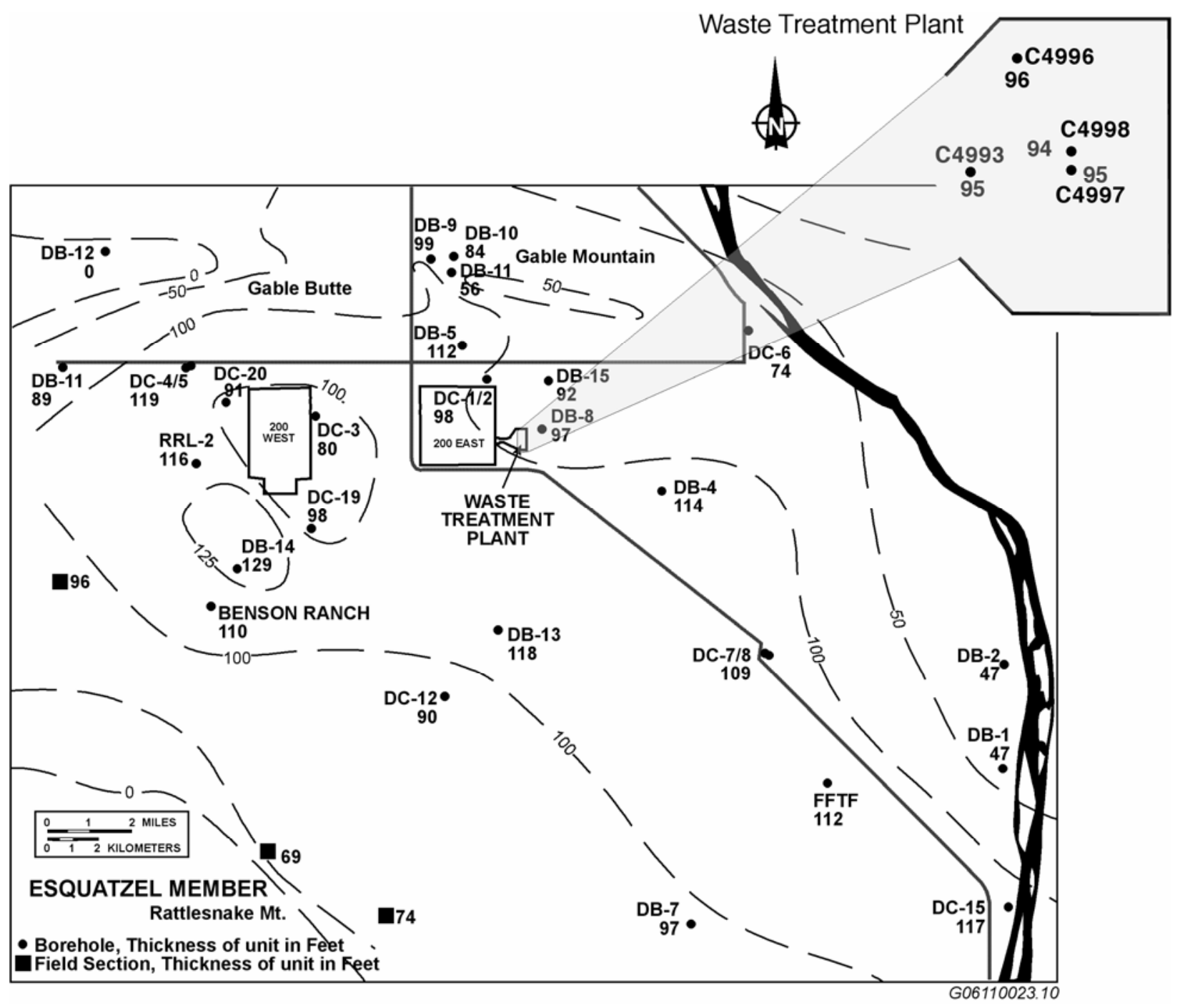

Figure 4.2. Esquatzel Member Thickness on the Hanford Site and at the Waste Treatment Plant Site

\subsubsection{Pomona Member}

The Pomona Member is separated from the Esquatzel Member by the Selah Interbed of the Ellensburg Formation. The Pomona Member consists of a single flow at the Hanford Site and has an average thickness of $43 \mathrm{~m}$ (142 ft) (Figure 4.3). At the WTP, the Pomona Member is between 186 and $209 \mathrm{ft}$ thick. 


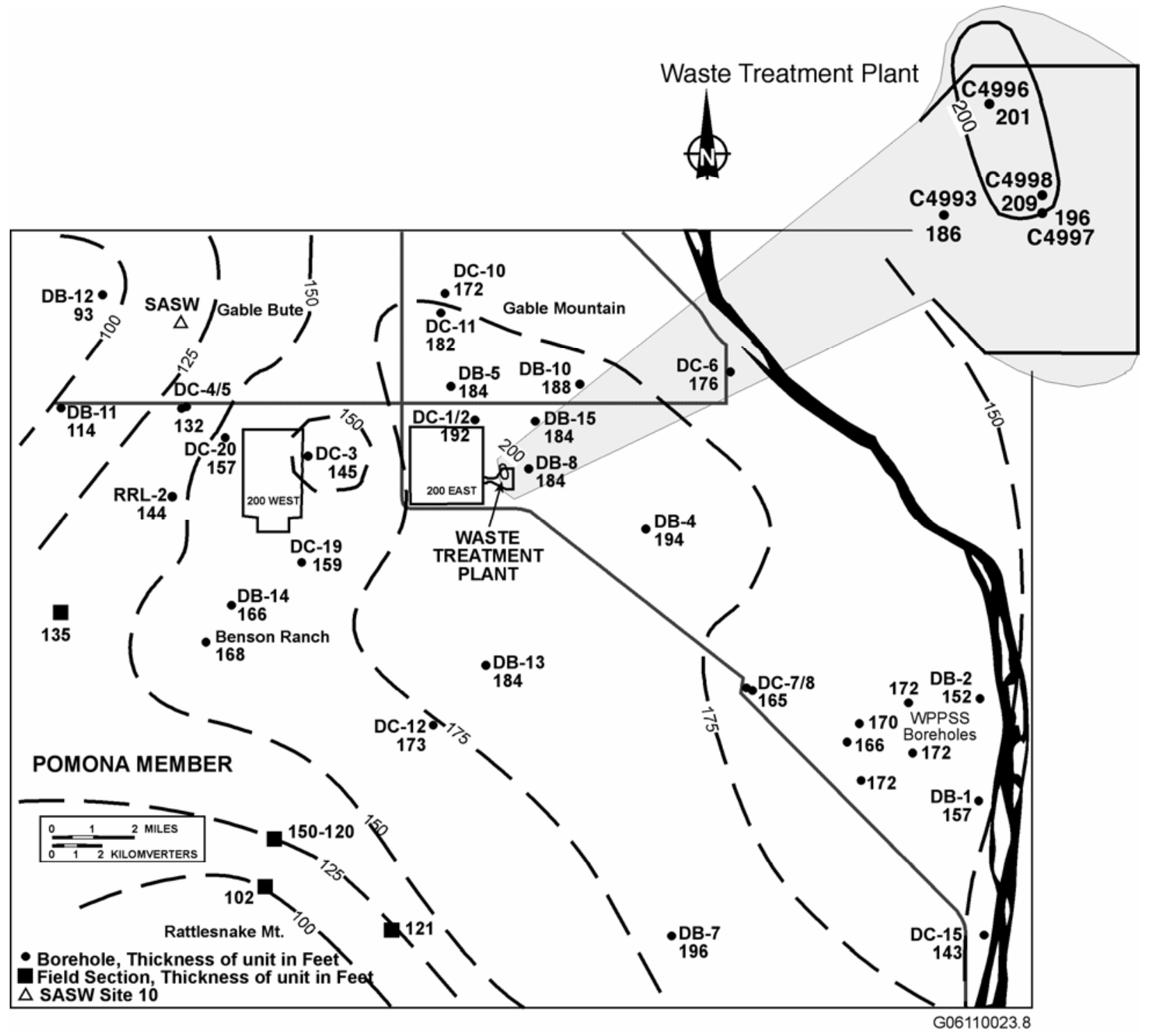

Figure 4.3. Pomona Member Thickness on the Hanford Site and at the Waste Treatment Plant Site

A flow-top breccia at the top of the Pomona Member was encountered in each borehole at the WTP site. A fault was interpreted in the flow-top breccia of core hole C4998 (Chapter 6). The flow-top breccia is interpreted to be the result of the lava flow invading sediment of the Selah Interbed.

\subsubsection{Elephant Mountain Member}

The Elephant Mountain Member is the uppermost Columbia River basalt unit beneath the WTP site and consists of a single flow. The flow, where present at the Hanford Site, has an average thickness of $91 \mathrm{ft}$ (Figure 4.4). At the WTP, the flow is between 104 and $118 \mathrm{ft}$ thick; the flow top has largely been removed by erosion. 


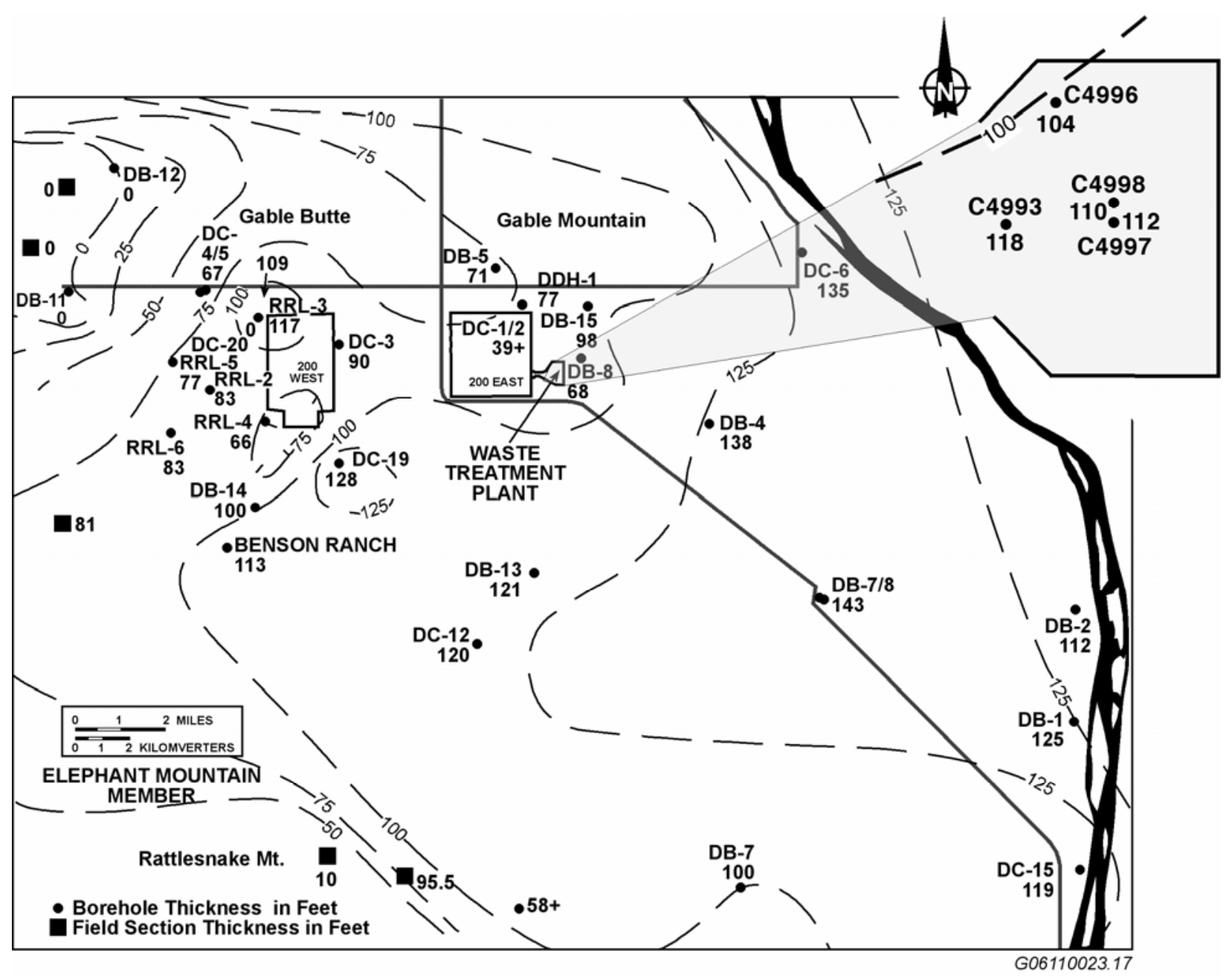

Figure 4.4. Elephant Mountain Member Thickness on the Hanford Site and at the Waste Treatment Plant Site 


\subsection{Ellensburg Sedimentary Deposits in and Around the Waste Treatment Plant Site}

This chapter presents a discussion of the Ellensburg Formation that is interbedded with and underlies the Saddle Mountains Basalt in the vicinity of the WTP. Five sedimentary interbeds of the Ellensburg Formation were encountered during the drilling of a core hole (C4998) and three boreholes (C4993, C4996, and C4997) at the site, as well as several boreholes that surround the site. Borehole C4996 encountered the Byron Interbed. The location of the boreholes is shown in Figure 1.2. The sedimentary interbeds that were encountered beneath the WTP site are consistent with those reported by Reidel and Fecht (1981). The interbeds at the WTP site are, from oldest to youngest, the Byron, Mabton, Cold Creek, Selah, and Rattlesnake Ridge. The Byron Interbed, a thin 5-ft-thick unit positioned between the Lolo and Rosalia flows of the Priest Rapids Member of Wanapum Basalt in borehole C4996, is not described further in this report. The stratigraphic relationships of the Ellensburg Formation and the Saddle Mountains Basalt are shown in Figure 2.3.

\subsection{Ellensburg Formation in the Vicinity of the Waste Treatment Plant Site}

Sediments of the Ellensburg Formation interbedded with the Saddle Mountains Basalt in the general vicinity of the WTP site are discussed in this section. The discussion is based on examination of core recovered from core hole C4998, as a well as interpretation of geophysical logs from selected boreholes. The interbeds included in the discussion are the Mabton, Cold Creek, Selah, and Rattlesnake Ridge (Figure 2.3). Interbeds beneath the Ice Harbor, Asotin, and Wilbur Creek members, as well as the Byron Interbed, are not pertinent to seismic issues at the WTP site and therefore are not discussed.

\subsubsection{Mabton Interbed}

The Mabton Interbed lies beneath the oldest member of the Saddle Mountains Basalt, the Umatilla Member. The Mabton Interbed is found throughout the vicinity of the WTP site (Figure 5.1). By definition, it is not present in the northern part of the Hanford Site because this area lies beyond the boundary of the Umatilla Member. The interbed is thickest in the central Hanford Site, up to $170 \mathrm{ft}$ thick. It thins to less than $50 \mathrm{ft}$ on to Rattlesnake Ridge and near the modern-day Columbia River. The Mabton typically consists of a thin basal mudstone bed(s) overlain by a relatively thick sequence of graded sandstone-siltstone beds. The basal mudstone unit consists of up to several beds of siltstone and claystone. The fine-grained units are horizontally laminated with the mudstone often massive and bioturbated consisting of superimposed paleosols. The mudstone is hard and compact to moderately well cemented with silica. The mudstone is composed mostly of epiclastic material, but thin lenses ( 2 to 5 in. thick) of tuffite and local tuffaceous beds have been observed in core samples and can be depicted in borehole natural gamma logs by an increase in gamma activity (Gardner and Price 2007).

\subsubsection{Cold Creek Interbed}

The Cold Creek Interbed refers to the Ellensburg sediments that occur stratigraphically between the Esquatzel and Umatilla members of the Saddle Mountains Basalt. The Asotin Member partially controls the distribution of the Cold Creek Interbed. The constructional topography that accumulated during 


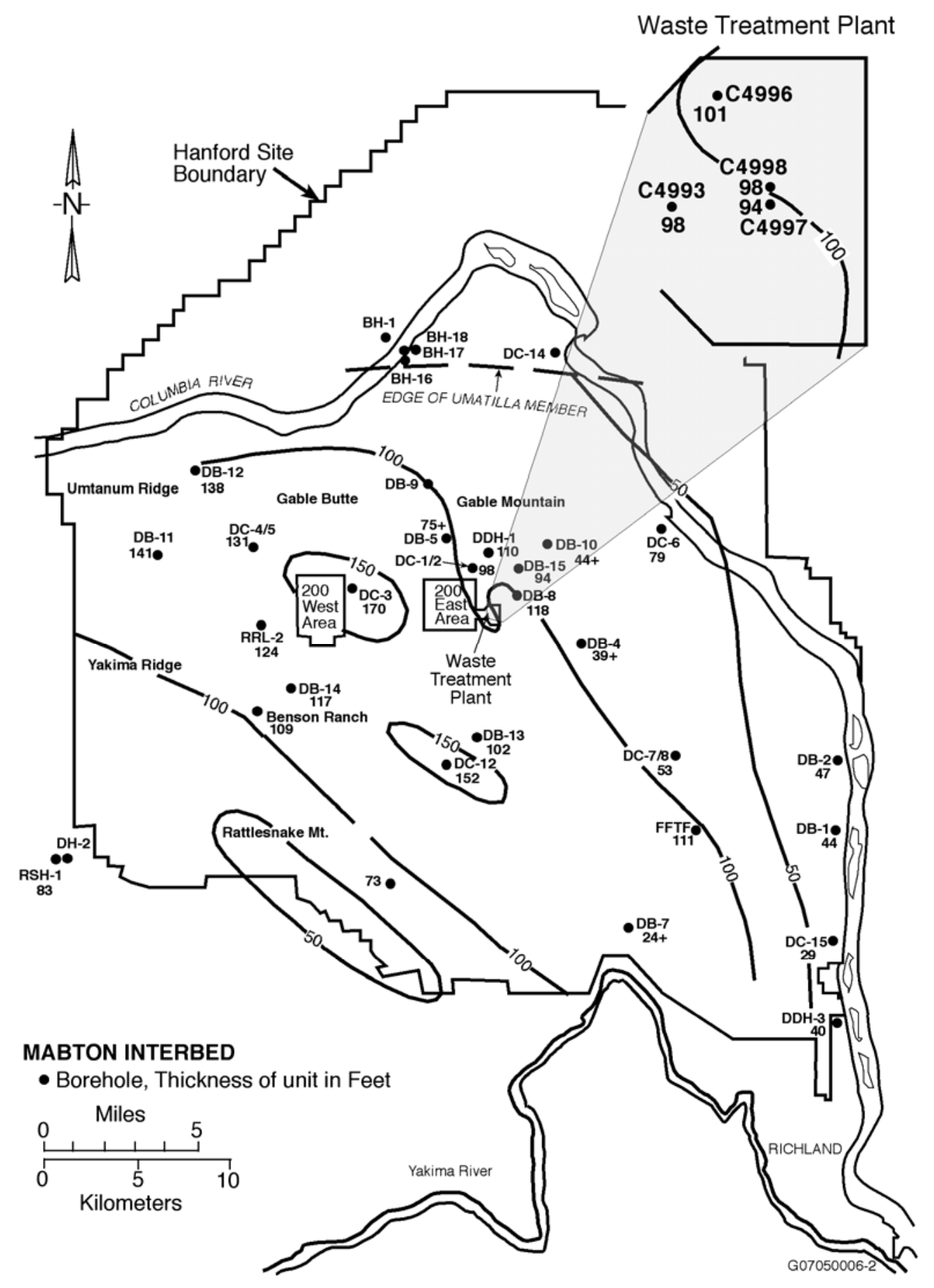

Figure 5.1. Mabton Sedimentary Interbed Thickness on the Hanford Site and at the Waste Treatment Plant Site

replacement of the Asotin Member has controlled the deposition of Ellensburg sediments to an area south of the Asotin Member (including the WTP site). The sediments are thickest in the central Hanford Site and thin and pinch out to the north against the constructional topography of the Asotin Member and to the southwest on to the structural topography of Rattlesnake Mountain (Figure 5.2). The interbed has been 
eroded from the northern portion of the Gable Gap area. The Cold Creek Interbed in the site vicinity is divided into two distinct textural facies associated with an ancient fluvial system (Fecht et al. 1987): 1) conglomerate-sandstone facies and 2) sandstone-siltstone facies. The conglomerate is a clastsupported, pebble-cobble gravel composed of over $50 \%$ basalt clasts and a sand matrix that is poorly sorted, typically coarse- to medium-grained, and composed chiefly of quartz and feldspar. The conglomerate is massive and weakly to moderately well cemented. The sandstone portion of the facies is poor to well sorted, typically coarse- to medium-grained, compact, and dense. The primary sedimentary structures include massive, horizontal, and cross (low-angle and high-angle) bedding. The sandstone is composed of quartz, feldspar, basalt, and glass shards. The conglomerate-sandstone facies contains discontinuous mudstone beds. The WTP site occurs within the conglomerate-sandstone facies. The sandstone in the sandstone-siltstone facies is similar in textural and mineralogical characteristics to the sandstone in the coarser grained facies, but also includes a wider range of particle sizes from coarse to very fine grained. The siltstone portion of the fine-grained facies is predominately siltstone, but includes claystone. The siltstone is often mottled, bioturbated, dense, and compact. The unit where mottled and bioturbated is massive and lacks observable internal sedimentary structures. Locally in intervals undisturbed by ancient surficial processes, remnants of horizontal laminations are observed in core samples.

\subsubsection{Selah Interbed}

The Selah Interbed is situated between the Pomona and Esquatzel members of the Saddle Mountains Basalt in the site vicinity. The interbed forms a thin sedimentary unit that is present over most of the site vicinity. It is up to about $72 \mathrm{ft}$ in the western portion of the Cold Creek syncline and thins and pinches out on to the Umtanum Ridge-Gable Mountain Structure and Rattlesnake Mountain (Figure 5.3). The interbed has been removed from parts of the Gable Gap area as a result of erosion by the ancient Columbia River and Pleistocene glaciofluvial flooding. The interbed in the vicinity of the WTP site consists mainly of sandstone-mudstone and mudstone units with local lenses of basaltic pebble conglomerate. The sandstone-mudstone units have a basal fine-grained sand that grades in size upward into a mudstone. The sandstone is massively to horizontally laminated, moderately well sorted, compact and dense. The sand is primarily composed of quartz and feldspar with minor to significant contributions from mica and basalt. The mudstone in the graded beds, as well as individual mudstone beds, varies in texture from siltstone to claystone. The mudstones are massive, poorly sorted, compact and dense. All beds show evidence of pedoturbation as a result of ancient surficial soil processes, commonly with soil joints infilled with opaline silica. The paleosols are poor to well-developed. Locally, the interbed is capped by a tuffite (airfall tephra commonly reworked by fluvial process) that is often baked during emplacement of the overriding Elephant Mountain flow to form a distinctive black perlitic ash.

\subsubsection{Rattlesnake Ridge Interbed}

The Rattlesnake Ridge Interbed is bounded by the overlying Elephant Mountain Member and the underlying Pomona Member. The contacts are sharp and distinct over much of the area except at Gable Mountain, where the Elephant Mountain flow is invasive into the upper part of the interbed. The Rattlesnake Ridge Interbed is present throughout the site vicinity, except locally the interbed pinches out onto structural ridges (e.g., Umtanum Ridge-Gable Mountain Structure and Rattlesnake Mountain) and is eroded from portions of the Gable Gap area (Figure 5.4). In the vicinity of the WTP site, the interbed is up to $100 \mathrm{ft}$ thick. The thickest sections occur in synclinal areas (i.e., the Wahluke and Cold Creek synclines) and thinnest on anticline ridges (Umtanum Ridge-Gable Mountain Structure and Rattlesnake 
Waste Treatment Plant

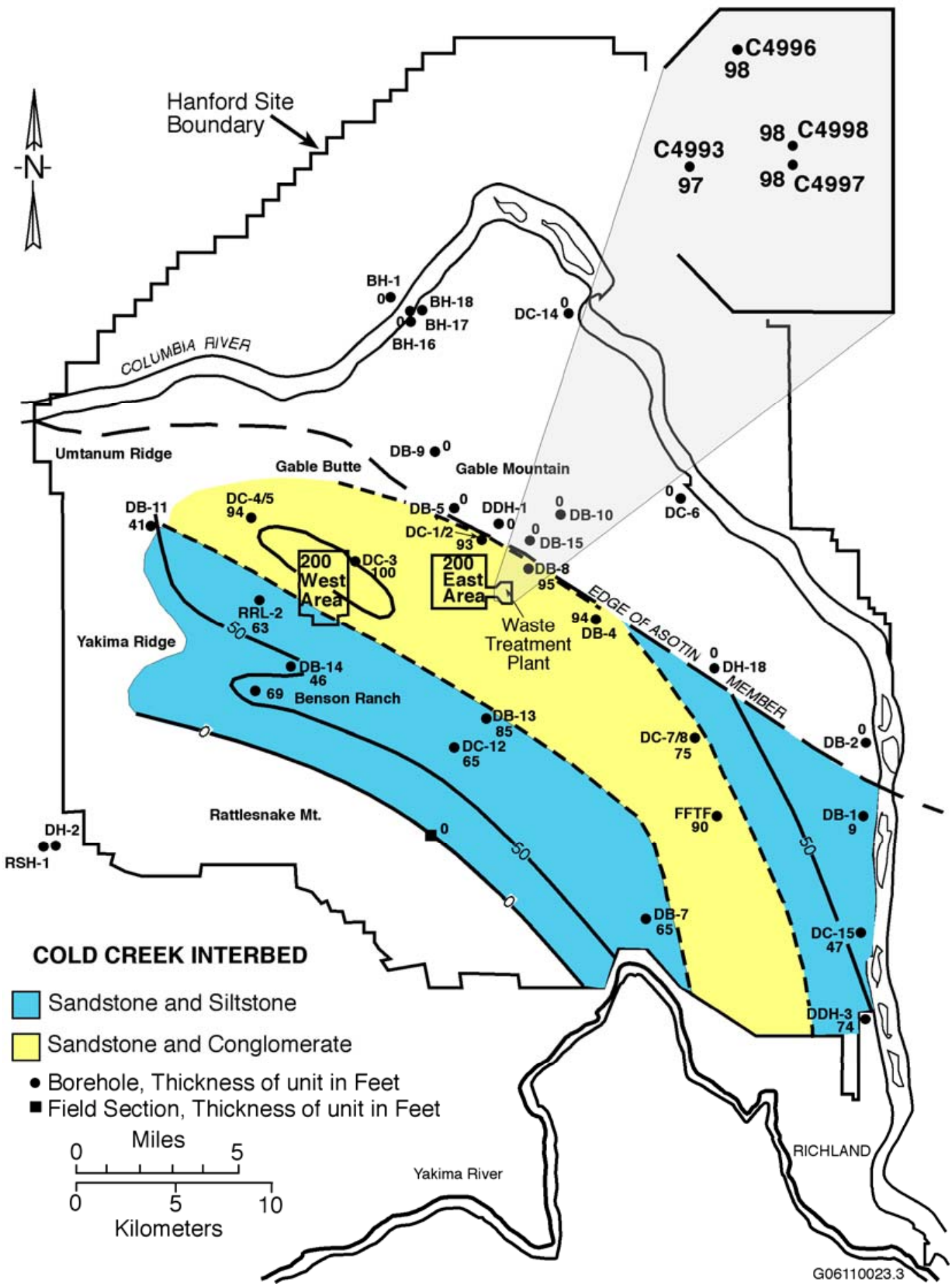

Figure 5.2. Cold Creek Sedimentary Interbed Thickness on the Hanford Site and at the Waste Treatment Plant Site 
Waste Treatment Plant

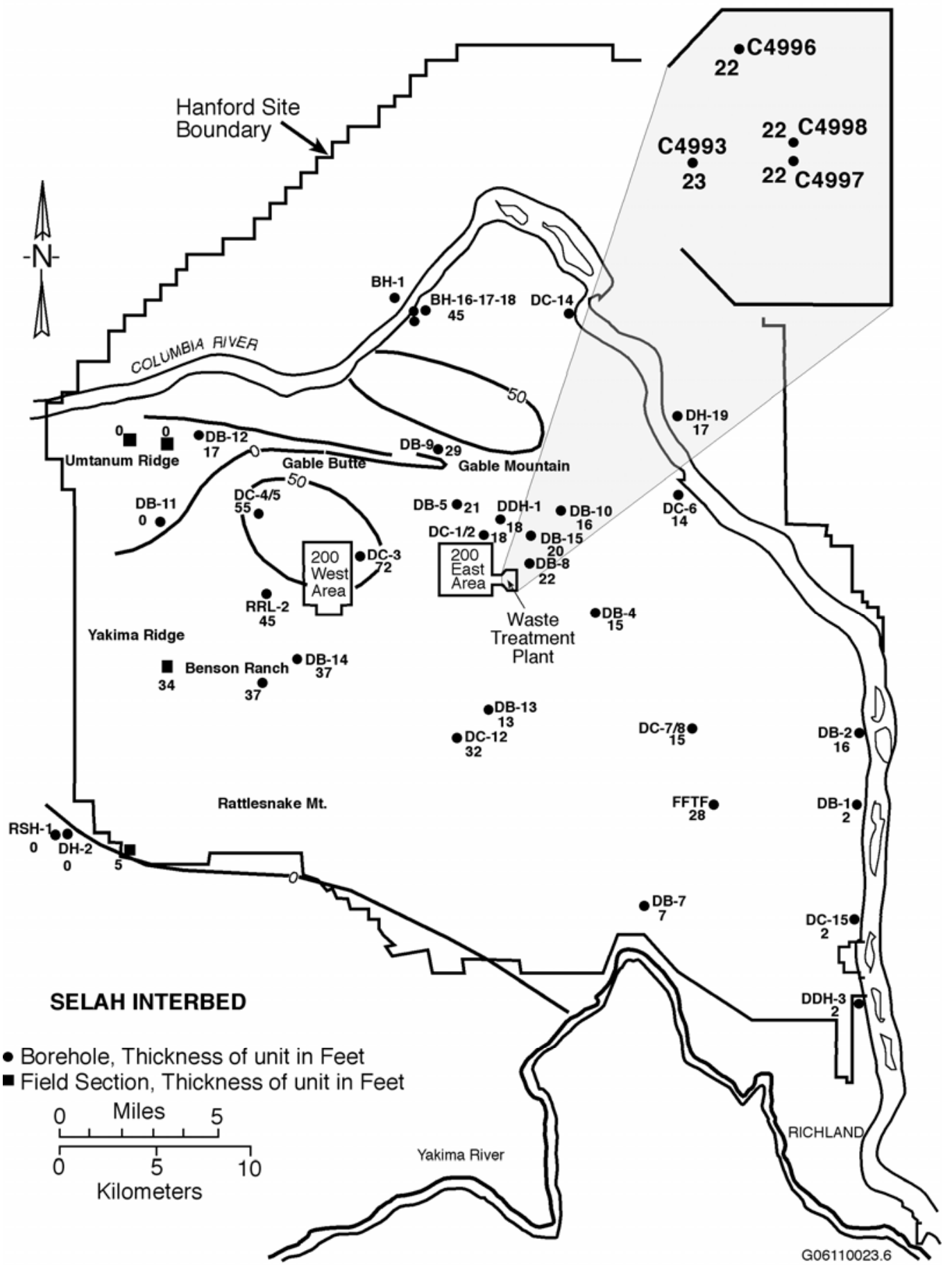

Figure 5.3. Selah Sedimentary Interbed Thickness on the Hanford Site and at the Waste Treatment Plant Site 


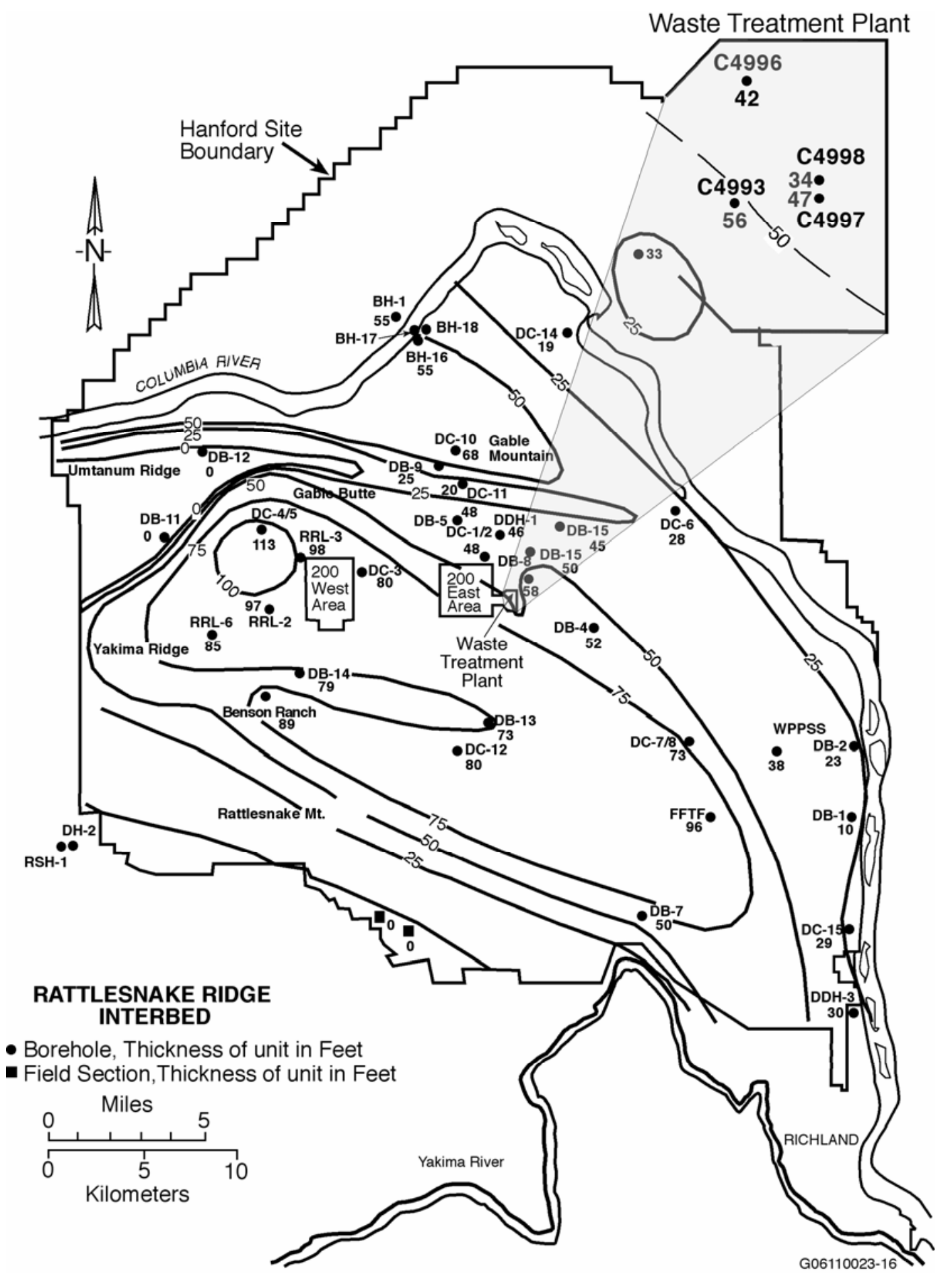

Figure 5.4. Rattlesnake Ridge Sedimentary Interbed Thickness on the Hanford Site and at the Waste Treatment Plant Site

Mountain). The interbed near the site can be divided into two distinct fluvial facies: 1) conglomeratesandstone facies and 2) sandstone-mudstone facies. The conglomerate-sandstone facies occurs northwest and west of the WTP site. The conglomerate portion of the facies consists of a clast-support gravel with 
mainly plutonic and metamorphic clasts and sand matrix with chiefly quartz and feldspar grains. The conglomerate-sandstone facies includes occasional mudstone lenses. The facies is generally moderately well sorted, bimodal size distribution (i.e., pebble-cobble gravel clasts and very coarse-to-medium sand particles), friable to compact with some local intervals cemented. The second facies, the sandstonemudstone facies, is primarily a sequence of normally graded beds. Individual beds consist of a lower sandstone with particles size of the sand fraction decreasing from very coarse-to-medium sand to fine sand to the north, east, and south of the vicinity of Gable Gap. The WTP site area occurs within the sandstone-siltstone facies of the Rattlesnake Ridge Interbed.

\subsection{Ellensburg Formation Sedimentary Interbeds at the Waste Treatment Plant}

\subsubsection{Mabton Interbed}

The Mabton Interbed underlies the Umatilla Member of the Saddle Mountains Basalt and overlies the Priest Rapids Member of the Wanapum Basalt. Beneath the WTP site, the interbed varies in thickness from 94 to $101 \mathrm{ft}$ and generally thins to the southeast (Figure 5.1). The interbed consists of a lower mudstone unit and an upper multistory sandstone-siltstone sequence (Figure 5.4). The mudstone unit consists of siltstone and claystone beds. These fine-grained beds commonly contain faint remnants of horizontal laminations that represent primary sedimentary structures. Elsewhere, these beds display mottled texture with organic debris and rootlets that is associated with incipient to well-developed paleosols. The mudstones vary from weakly indurated to compact.

The sandstone-siltstone sequence forms a multistory series of upward fining beds. In core hole C4998 (Figure 5.5), six stories were observed and vary in thickness from 5 to $17 \mathrm{ft}$. Sandstone typically forms the basal sediments of each bed. Individual sand particles have a range of sizes that vary from very coarse to fine grained. The sandstone occasionally contains silt within the matrix or pebbles composed of rounded siltstone. The mineralogy of the sandstone is dominated by quartz and feldspar with minor to trace amounts of mica and basalt fragments. The sandstones are poorly to moderately well sorted and compact. The basal sand within beds decreases in particle size upward and at the top of the bed the sediments are dominated by the silt size fraction. The silt is poorly sorted and bioturbated from superimposed paleosols. The silt units are sufficiently compact or well indurated to be characterized as siltstones. Several beds within the sandstone-siltstone sequence contain an abundance of volcanic tuff mixed with epiclastic sediments. Beds with high proportions of tuffaceous sediments have been identified in natural gamma logs based on high count rates associated with naturally occurring radioactive elements (potassium, uranium, and thorium). Epiclastic sediments typically have lower count rates than volcanic tuffs. The uppermost bed of the Mabton Interbed is baked and well indurated as a result of heat generated during the emplacement of the overriding Umatilla flow.

Four short intervals ( 1 to $3 \mathrm{ft}$ thick) of core were not recovered during drilling operations of core hole C4998. These intervals are commonly associated unconsolidated sand that was washed out of the hole and lost during core recovery. Such intervals are typically reflected in the caliper surveys of boreholes and record an increased bore diameter that is significantly larger than the drill bit diameter. Several short intervals in boreholes C4993, C4996, and C4997 may have been washed out within the Mabton Interbed based on review of caliper log surveys (Gardner and Price 2007). 


\section{C4998(WTP) - Mabton}

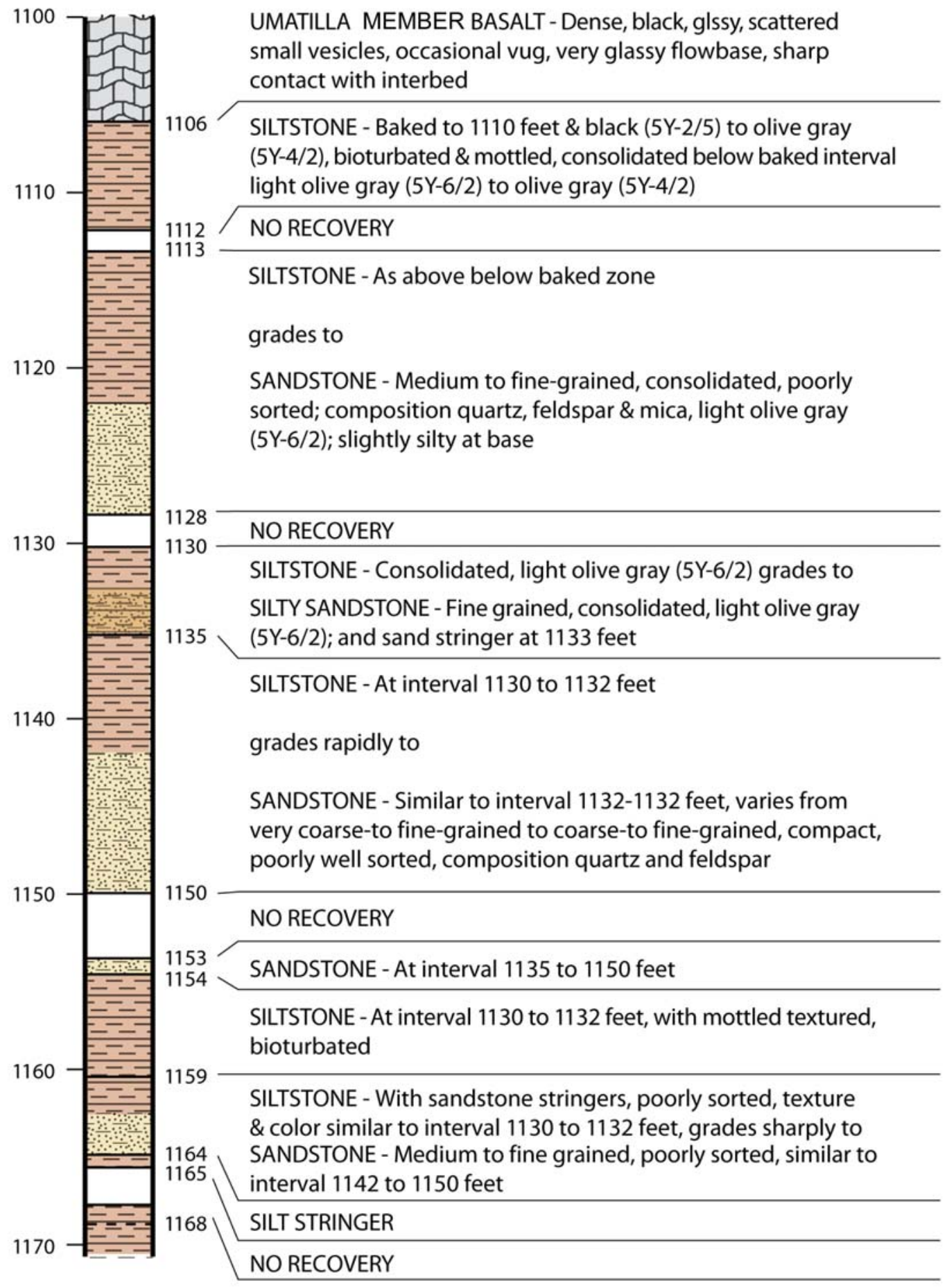

Figure 5.5. Stratigraphic Column of the Mabton Interbed in Core Hole C4998 


\section{C4998(WTP) - Mabton (cont'd)}

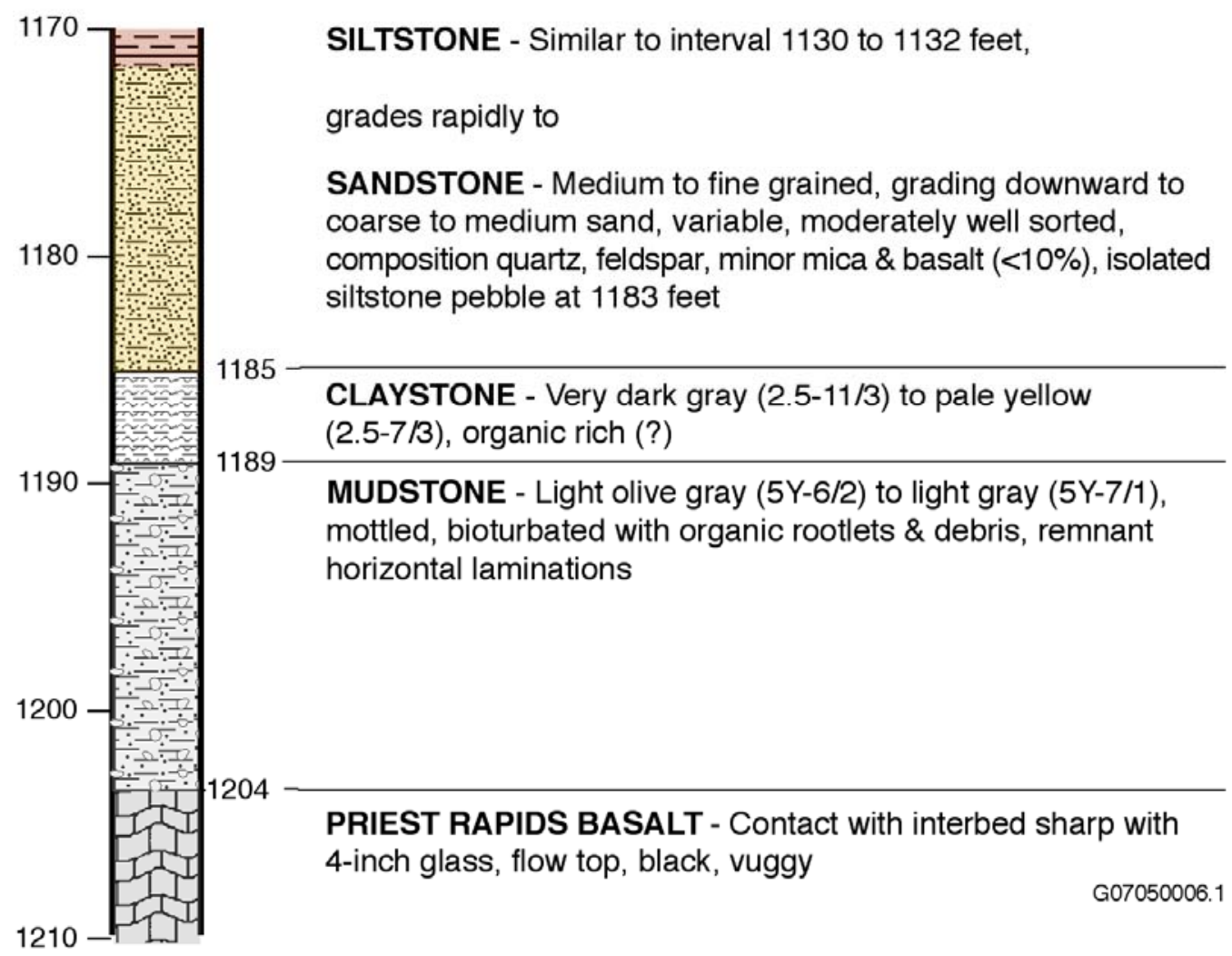

Figure 5.5. Stratigraphic Column of the Mabton Interbed in Core Hole C4998 (contd)

\subsubsection{Cold Creek Interbed}

The Cold Creek Interbed at the WTP site occurs between the Umatilla and Esquatzel members of the Saddle Mountains Basalt. The contacts with the bounding basalt flows are generally distinct with the overlying flow having baked the top of the interbed. The Cold Creek Interbed varies in thickness across the site from 97 to $98 \mathrm{ft}$ (Figure 5.2). The beds in the lower part of the interbed consist mainly of mudstone, whereas the beds in the upper part of the sedimentary sequence are sandstone-siltstone (Figure 5.6). The mudstone beds display variable particle sizes that include silt, clay and interbedded clay and sand. The mudstones are compact and dense. Primary sedimentary structures are rarely observed in the mudstones, but where present occur as faint remnant horizontal laminations. Elsewhere, primary sedimentary structures have been destroyed by ancient soil forming processes. In the overlying sandstone-siltstone unit, beds form as multiple sets of normally graded units. The graded beds have sandstone bases that fine upward to siltstone. The sand particles in the sandstone vary in size from fine-grained to very coarse-tomedium grained. The sandstone contains pebble clasts near the base of the coarsest units. The mineral composition of the sandstone is dominated by quartz and feldspar with minor contributions from mica, basalt fragments, and volcanic shards. The primary sedimentary structures vary from horizontal to crosslaminated to massive beds. The sandstone intervals are friable to compact. The friable intervals are prone to washing out and often enlarge the borehole diameter during drilling operations. Several of these 
zones can be seen in the caliper surveys of boreholes C4993, C4996, and C4997 (Gardner and Price 2007). The upper portion of the sandstone-siltstone beds is siltstone, with the siltstone having similar characteristics to the siltstone in the lower beds. The siltstone from the top graded beds in core hole C4998 (Figure 5.6) displays mottled soil structure associated with superimposed paleosols. The siltstone in the graded bed sequence is compact and dense.

\section{C4998(WTP) - Cold Creek Interbed}

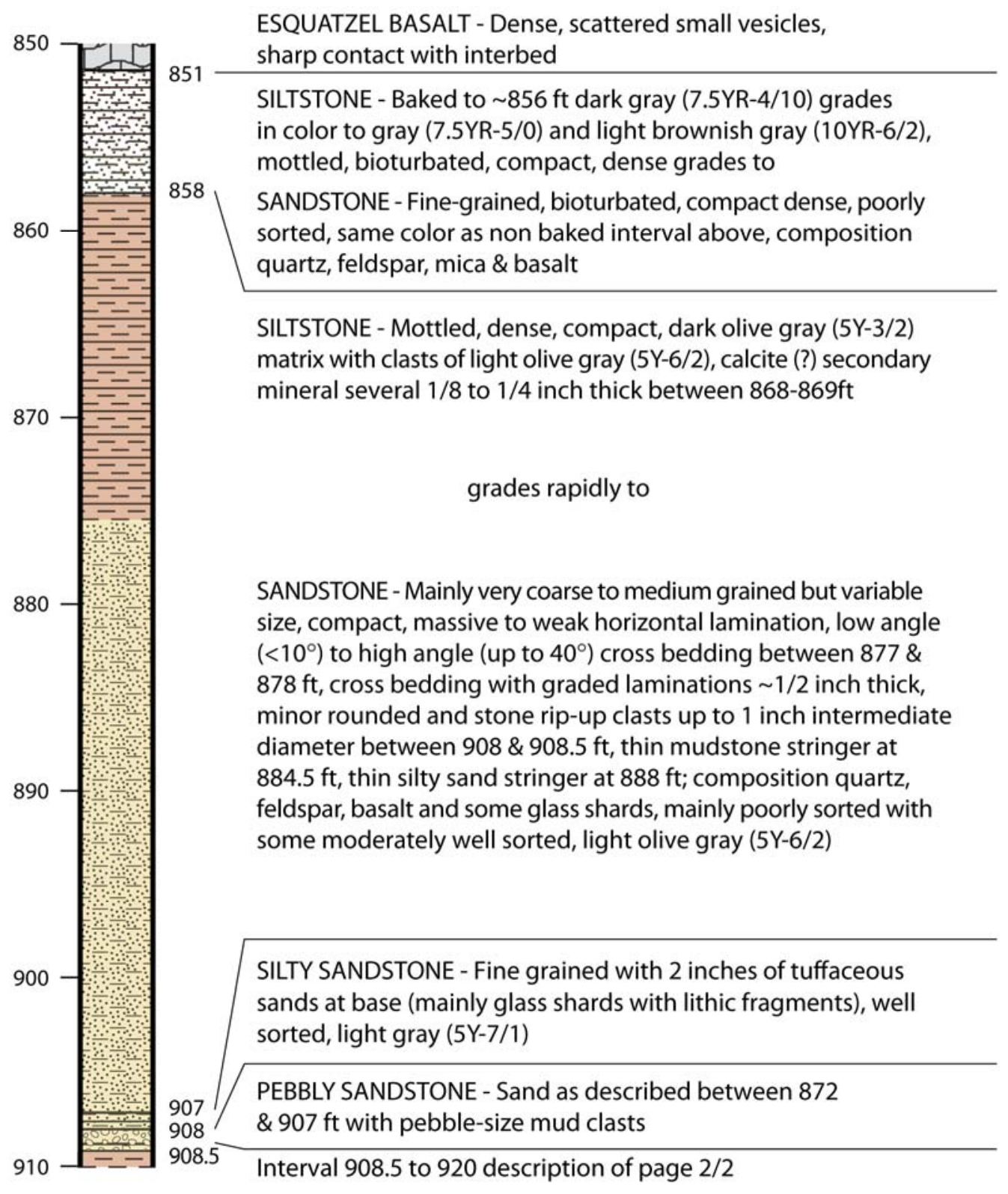

G06110008-3

Figure 5.6. Stratigraphic Column of the Cold Creek Interbed in Core Hole C4998 


\section{C4998(WTP) - Cold Creek Interbed (cont'd)}

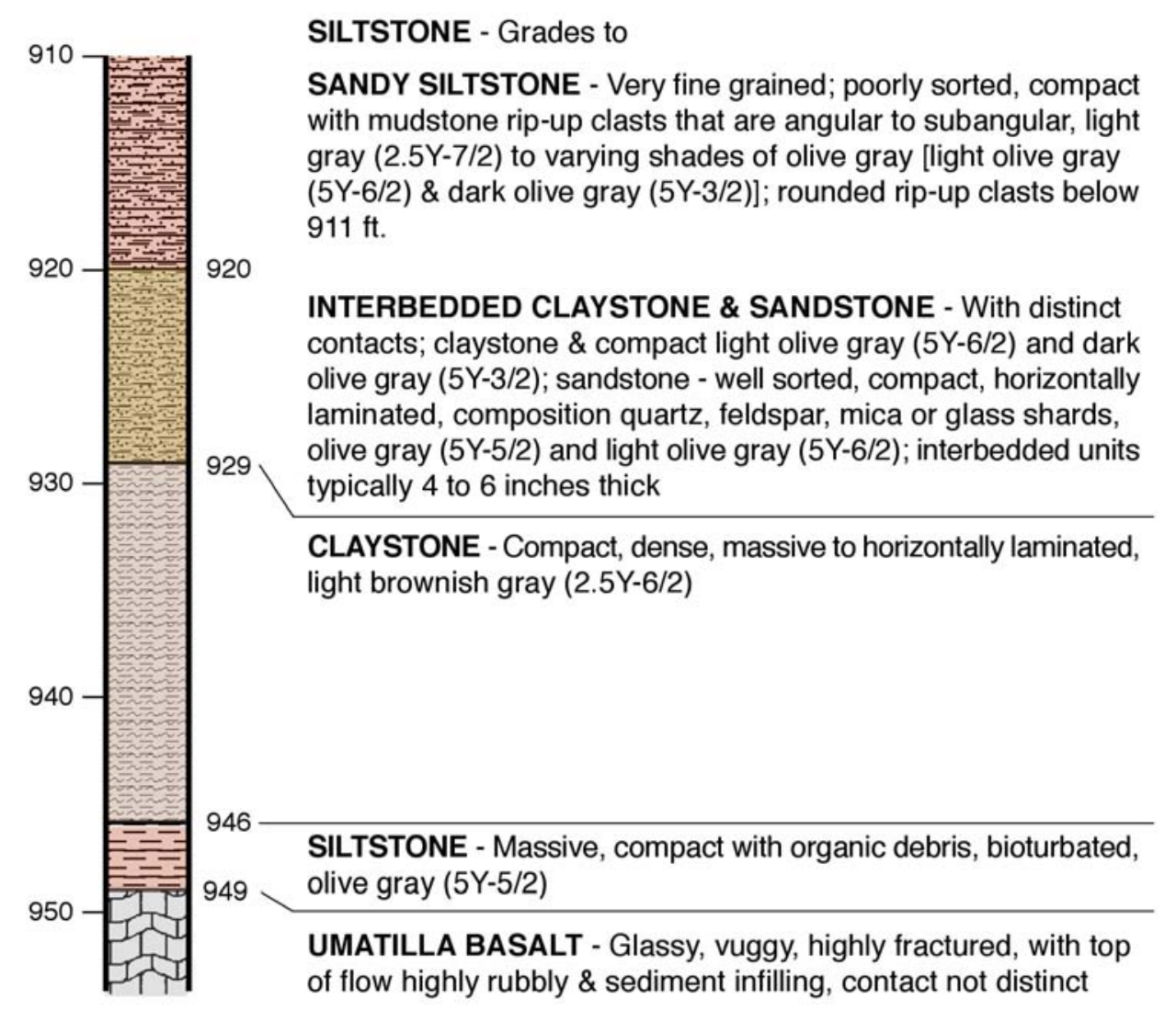

G06110008-4

Figure 5.6. Stratigraphic Column of the Cold Creek Interbed in Core Hole C4998 (contd)

\subsubsection{Selah Interbed}

The Selah Interbed occurs between the Pomona and Esquatzel members of the Saddle Mountain Basalt. The contact with the basalt members is sharp and distinct. The interbed is 22 to $23 \mathrm{ft}$ thick beneath the WTP site (Figure 5.3). The interbed is relatively thin compared to other Ellensburg interbeds intercalated with Saddle Mountains Basalt at the WTP site. The interbed consists of a lower claystone that is compact and dense with mottled texture associated with ancient incipient soil development (Figure 5.7). The claystone contains several small clasts of basalt that were likely derived from local erosion of the Esquatzel flow. Above the claystone, the interbed consists of several normally graded beds. The coarser fraction of the sedimentary beds is fine-grained sandstone. The sand fraction is composed mainly of quartz and feldspar with minor amounts of mica and basalt fragments. An occasional significant increase in borehole diameter occurs in boreholes C4993, C4996, and C4997 based on caliper surveys through the Selah Interbed (Gardner and Price 2007). These intervals are thin, 1 to $3 \mathrm{ft}$ thick, and indicate thin washed-out intervals that likely occur in zones of friable sandstone. The upper portion of graded beds consists of mudstone, mainly claystone. The mudstone units atop most beds have been extensively modified by ancient surficial processes that formed mottled structure and infilling of soil joints by secondary mudstone. 


\section{C4998(WTP) - Selah Interbed}

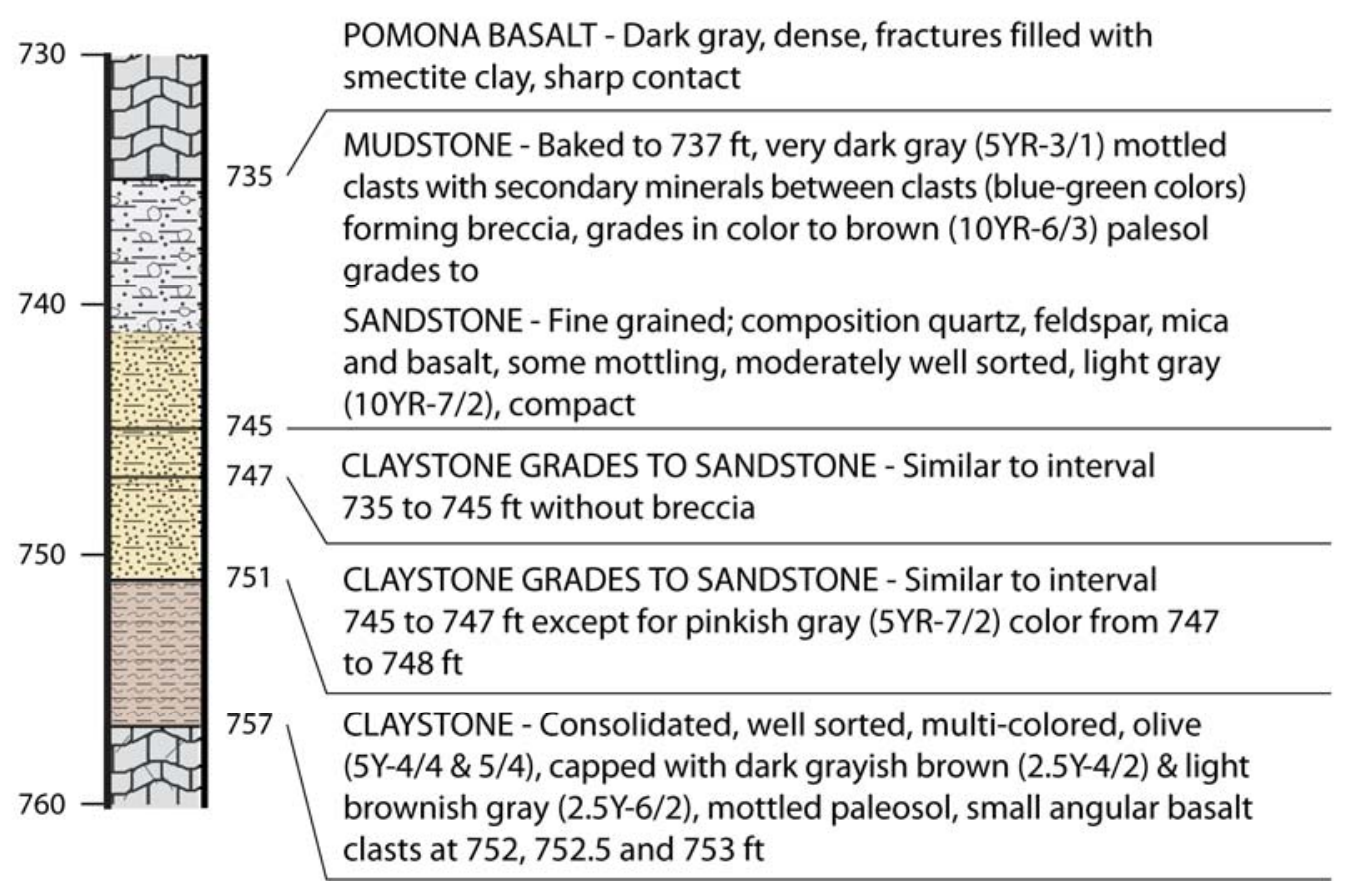

ESQUATZEL BASALT - Vesicular, welded flow-top breccia, multicolored red, olive, gray \& black

$$
\mathrm{T}=22
$$

G06110008-2

Figure 5.7. Stratigraphic Column of the Selah Interbed from Core Hole C4998

\subsubsection{Rattlesnake Ridge Interbed}

The Rattlesnake Ridge Interbed is the uppermost interbed at the WTP site and lies between the Pomona and Elephant Mountain members of the Saddle Mountains Basalt. The upper and lower contracts are sharp and distinct. The interbed varies in thickness from 34 to $56 \mathrm{ft}$ across the WTP site (Figure 5.4). In the lower portion of the interbed, one (or more) upward fining bed is present, it grades from a basal very coarse-to-medium grained sandstone upward into a capping mudstone (Figure 5.8). The lower sandstone portion of the beds consists of quartz, feldspar, basalt, and mica with minor organic debris. Opaline silica, a secondary mineral, is present in the lowest bed. Each bed has a soil horizon superimposed on the original sedimentary deposits to form a mottled paleosol. The sandstone is mainly medium- to coarsegrained sand with thin lenses of very coarse-grained sand. Near the middle of the sedimentary sequence, a tuffite that consists of silty sandstone with distinctive angular very fine-grained sand-size particles and is composed of glass shards (airfall tephra that has been reworked by fluvial processes). The tuffite grades upward into a tuffaceous mudstone. The uppermost sedimentary unit forms a normally graded bed with a basal sandstone and an upper mudstone, and is similar to graded beds in the lower part of the interbed. The bedding sequence forms a distinct pattern of epiclastic and volcaniclastic sediments that can be correlated in and around the WTP site (Figure 5.9). 


\section{C4998(WTP) - Rattlesnake Ridge Interbed}

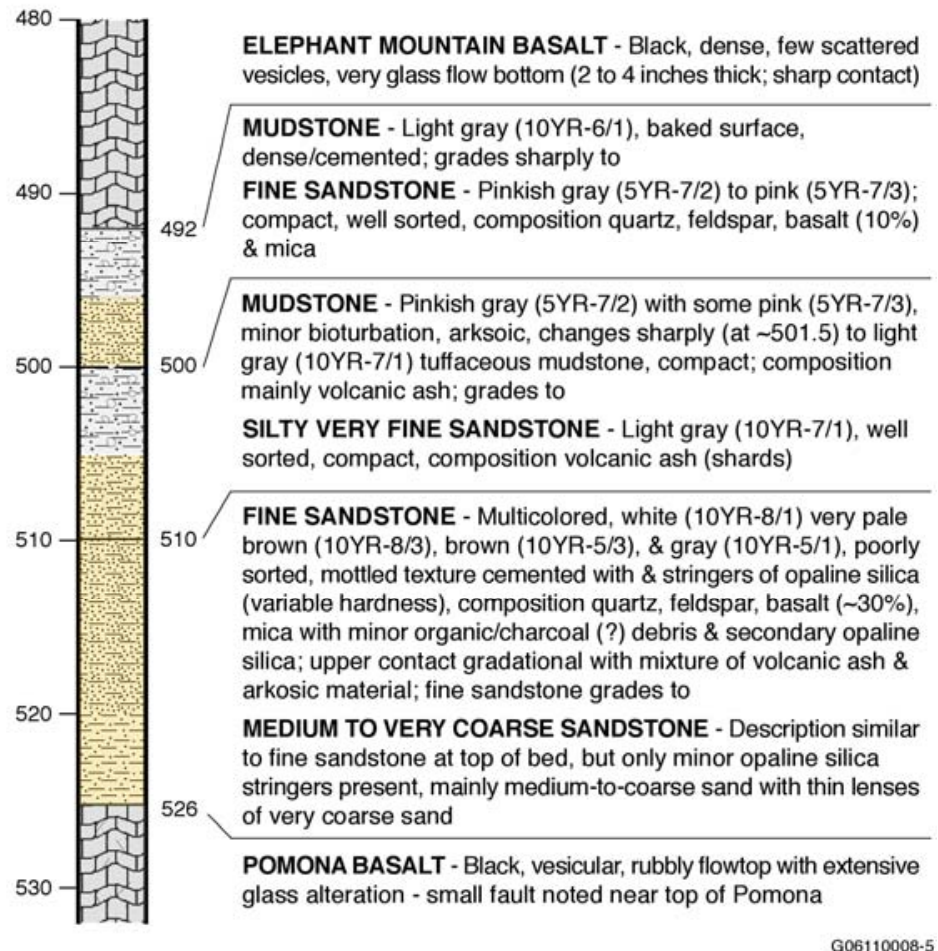

Figure 5.8. Stratigraphic Column of the Rattlesnake Ridge Interbed in Core Hole C4998

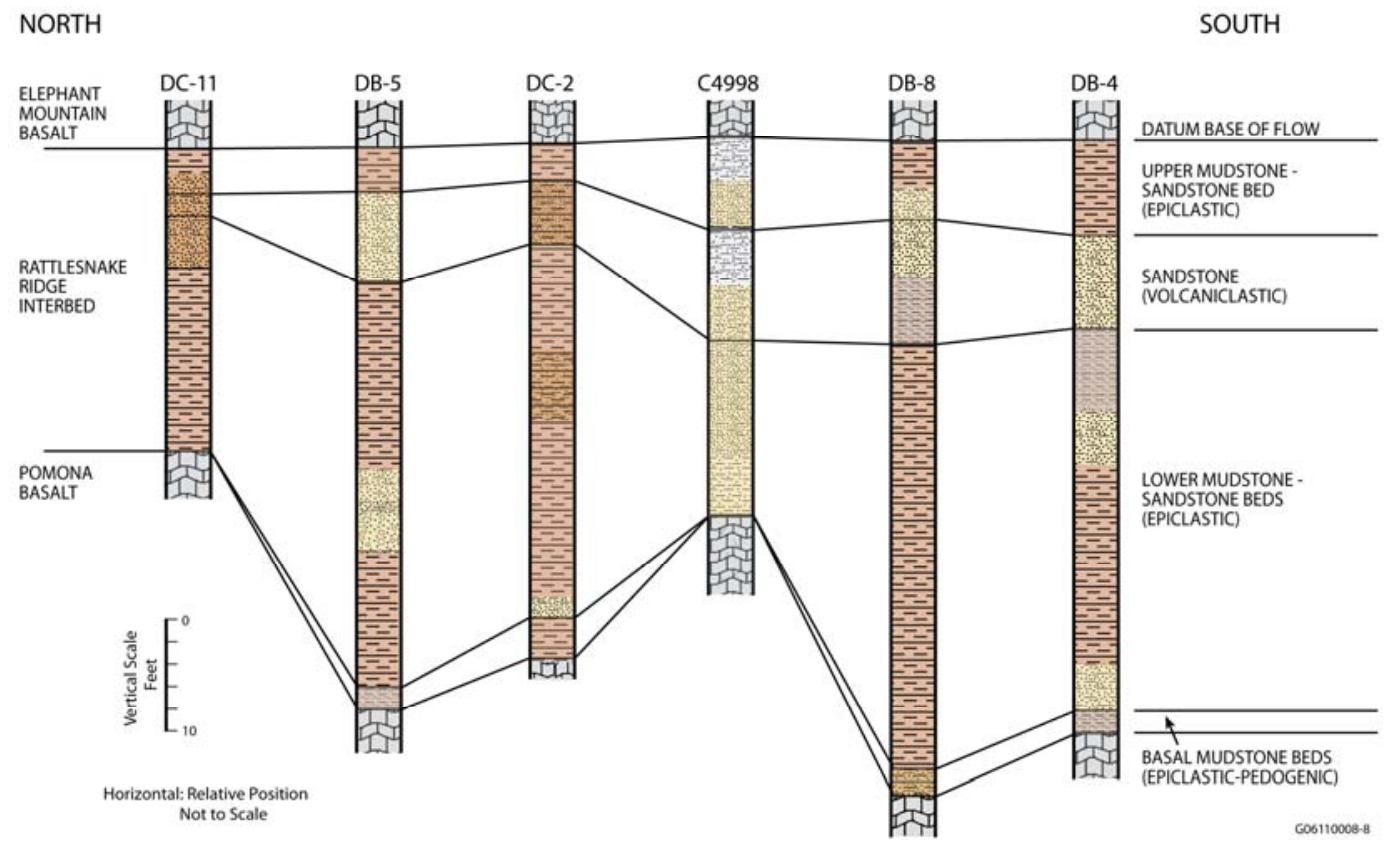

Figure 5.9. North to South Cross Section of the Rattlesnake Ridge Interbed Through the Waste Treatment Plant Site 


\subsection{Structural Geology at the Waste Treatment Plant Site}

The Hanford Site and WTP lie within the Yakima fold belt (Figure 6.1), a series of generally east-towest trending anticlines and synclines that cover most of the western Columbia Basin. The surface of the Columbia River Basalt Group at the Hanford Site provides a first-order measure of the anticlinal and synclinal features of the Hanford Site (Figure 6.2). Overall, there is a general northwest-to-southeast structural trend with an east to west structural trend superimposed on it. The structure at the WTP, as reflected in the surface of the Columbia River Basalt Group, has a general east-to-west trend, with elevations increasing northward toward Gable Mountain and decreasing south toward the axis of the Cold Creek syncline (Figures 6.2 and 6.3).

\subsection{Top of Basalt}

The surface of basalt at the Hanford Site is erosional resulting from prolonged exposure after the last basalt lava flow was erupted. The WTP lies within a channel of the ancestral Columbia River and the Pleistocene floods. Cuttings samples and core from the seismic boreholes at WTP did not show evidence for vesicular flow tops indicating that at least several feet had been removed from the surface of the Elephant Mountain Member. Because of this erosion, the surface of the basalt at WTP and the surrounding area does not represent a true structural surface.

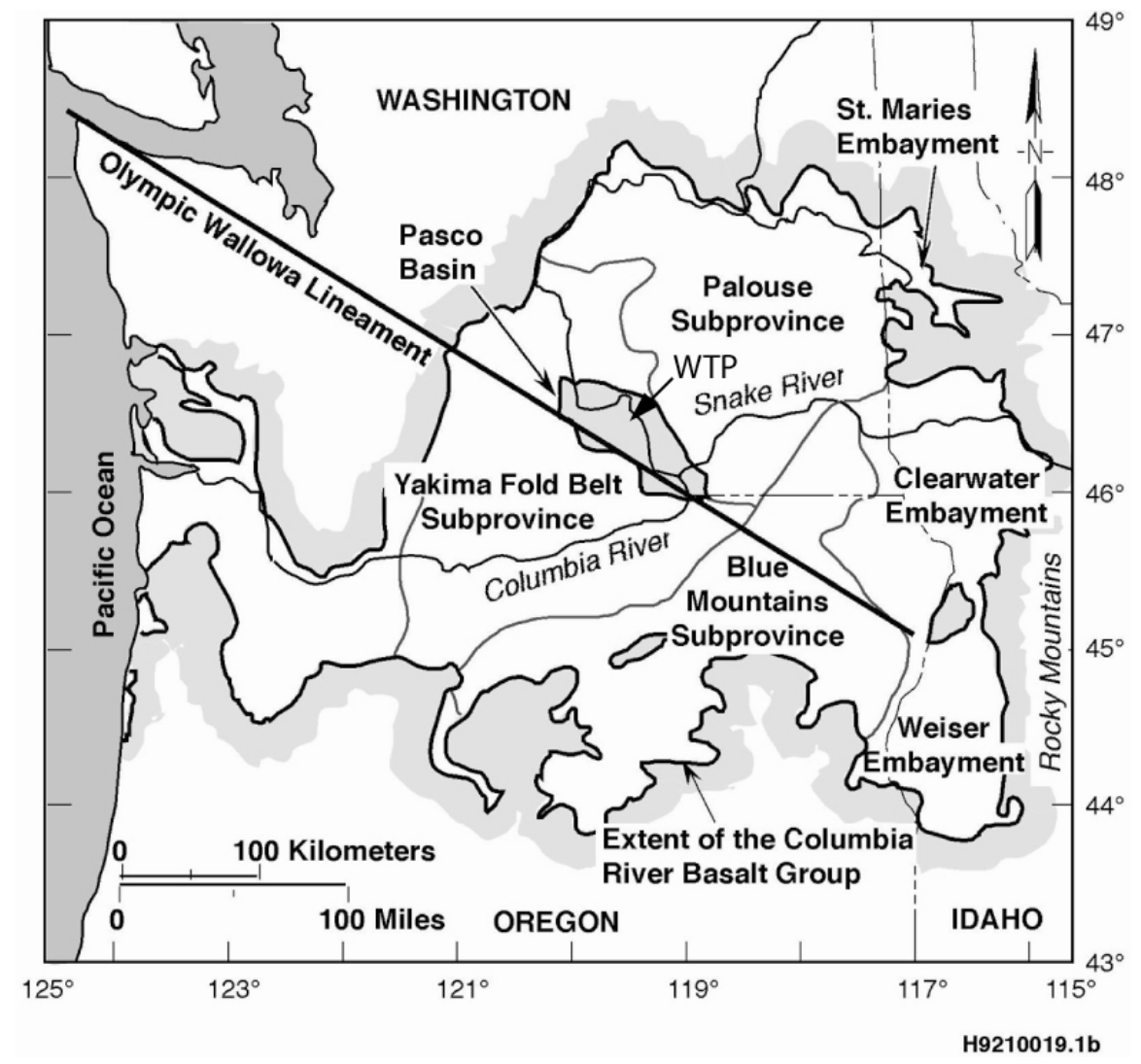

Figure 6.1. Location of the Waste Treatment Plant in the Yakima Fold Belt 
Top of Basalt Elevation in feet

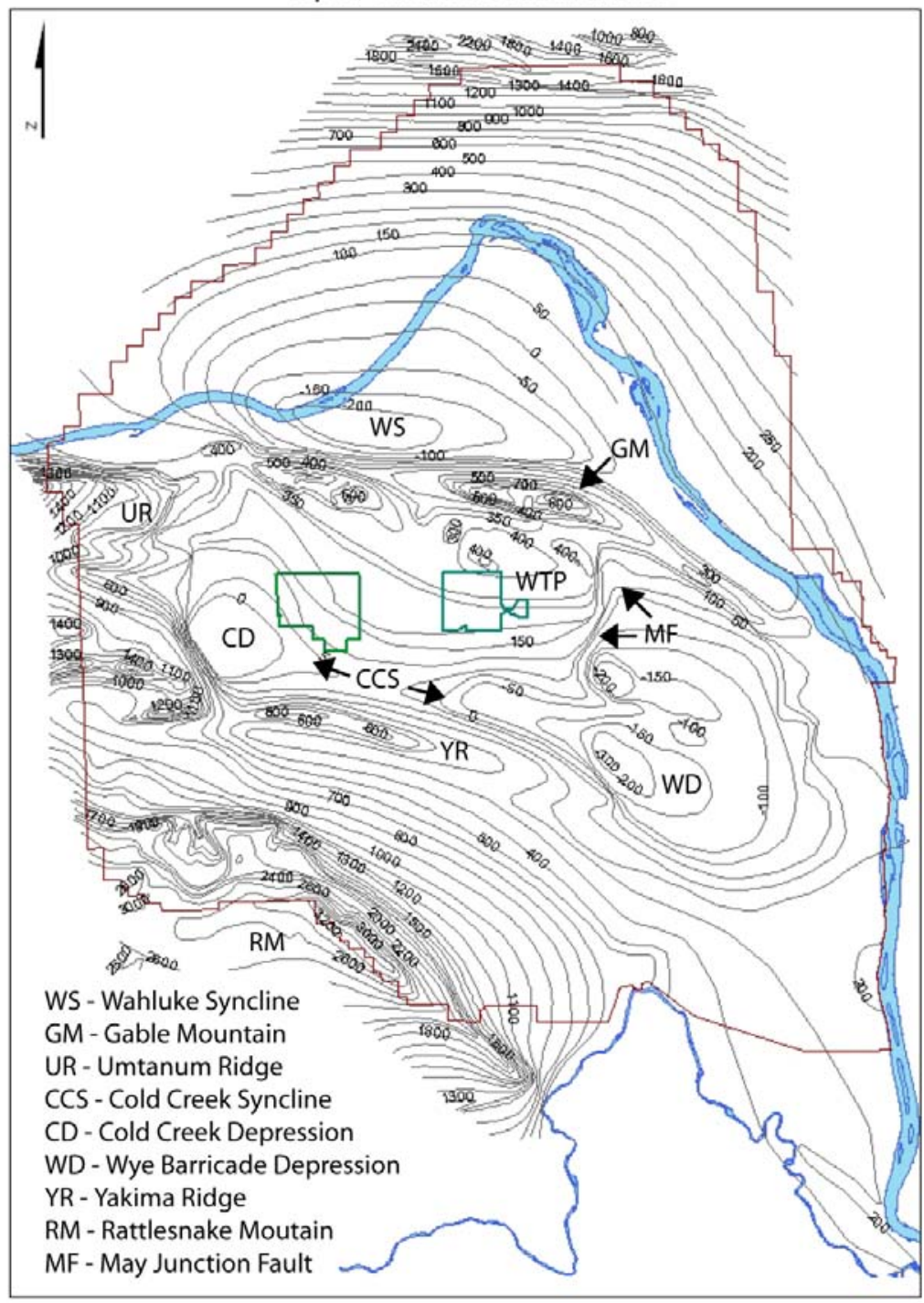

Figure 6.2. Generalized Elevation of the Columbia River Basalt Group Beneath the Hanford Site. Contour interval is $50 \mathrm{ft}$.

Both the general pattern of the thickness of the basalts and Ellensburg Formation sediments follow the same northwest-to-southeast trend that is seen in the surface of the basalt map (Figures 4.5 through 4.8, and Figures 5.1 through 5.4.

Figures 6.4 through 6.10 are maps showing the elevation of the surface of the lava flows and sedimentary interbeds at the WTP and the surrounding area. The contours have been left off of these diagrams because of the sparse data points. However, the general trend of the surface of the geologic units at the WTP fits with the general pattern observed on the top of basalt maps and regional thickness trend maps. That is, the surface of each unit becomes lower in elevation to the south into the Wye Barricade Depression and higher to the north toward Gable Mountain and Umtanum Ridge. The elevations of units at the WTP are consistent with the overall regional trends. 


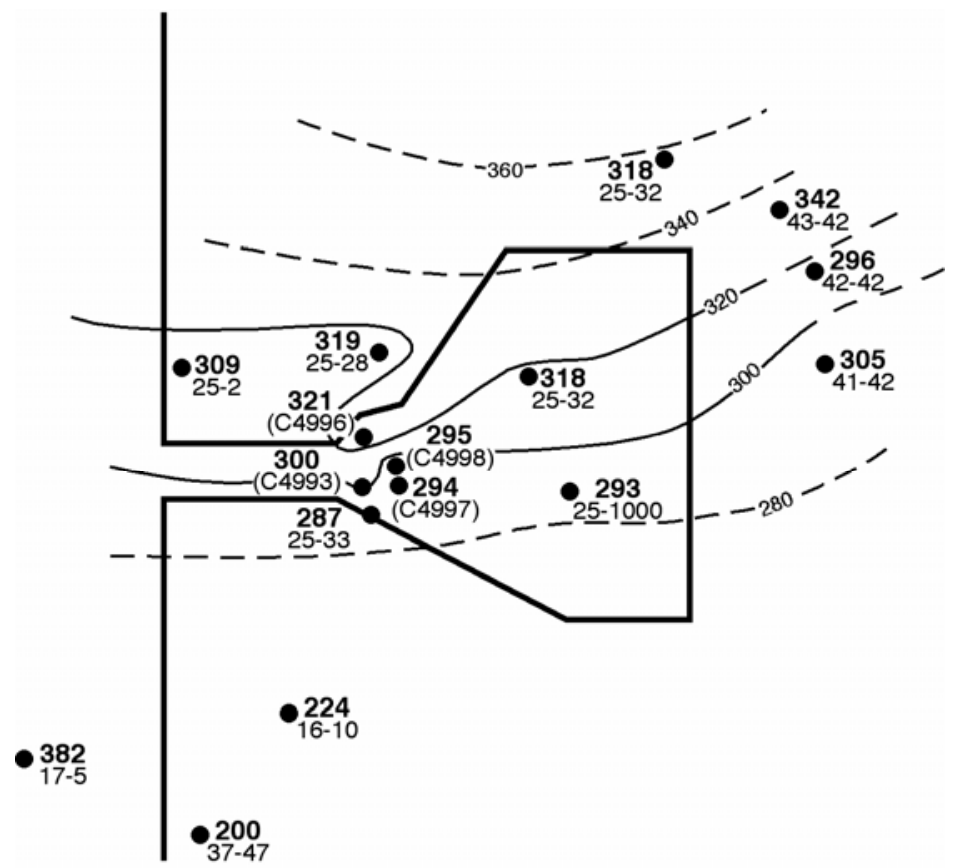

G06110008-1

Figure 6.3. Elevation of the Top of the Columbia River Basalt at the Waste Treatment Plant Site. Contour interval is $20 \mathrm{ft}$.

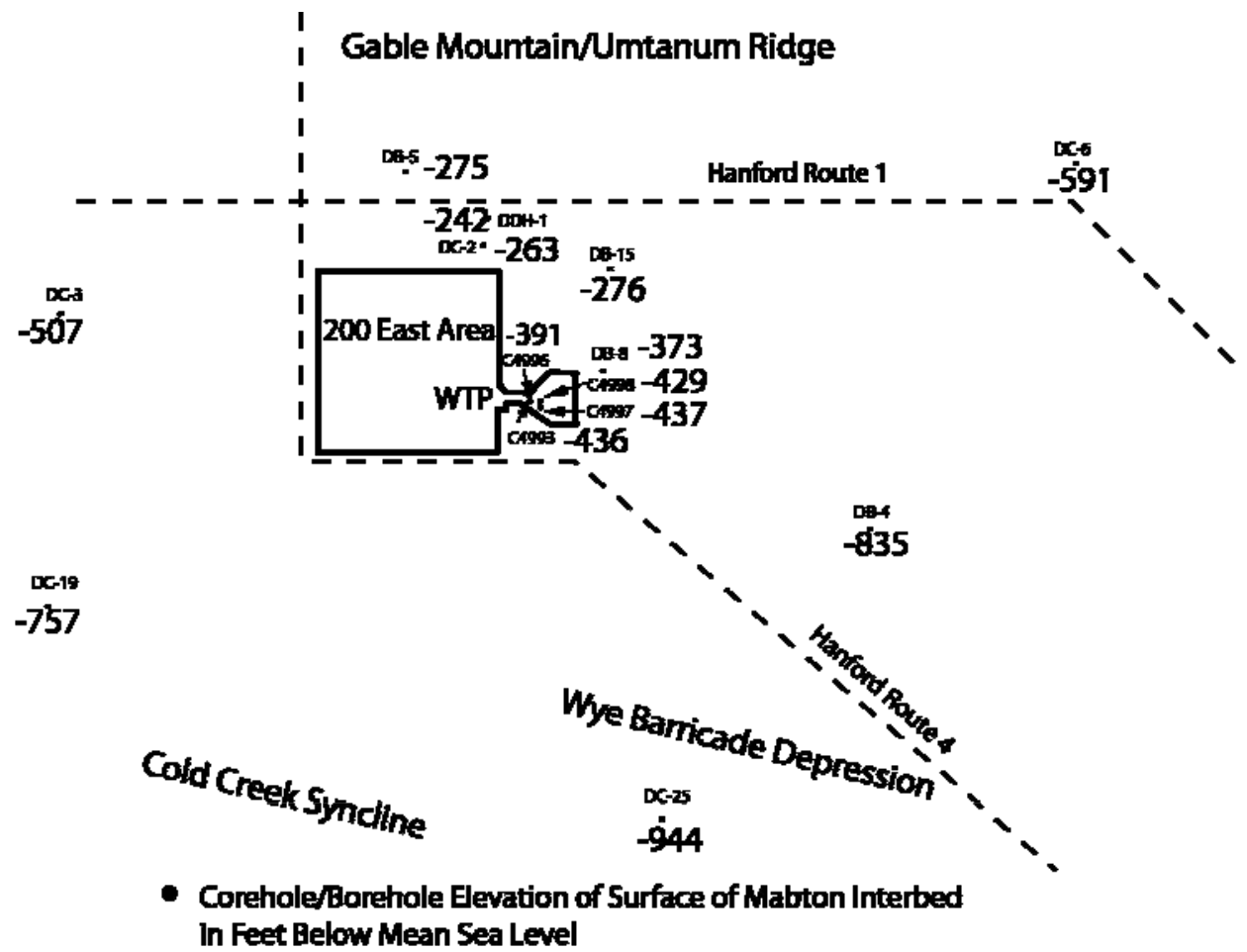

Figure 6.4. Elevation of the Surface of the Mabton Sedimentary Interbed in Boreholes near and at the Waste Treatment Plant 


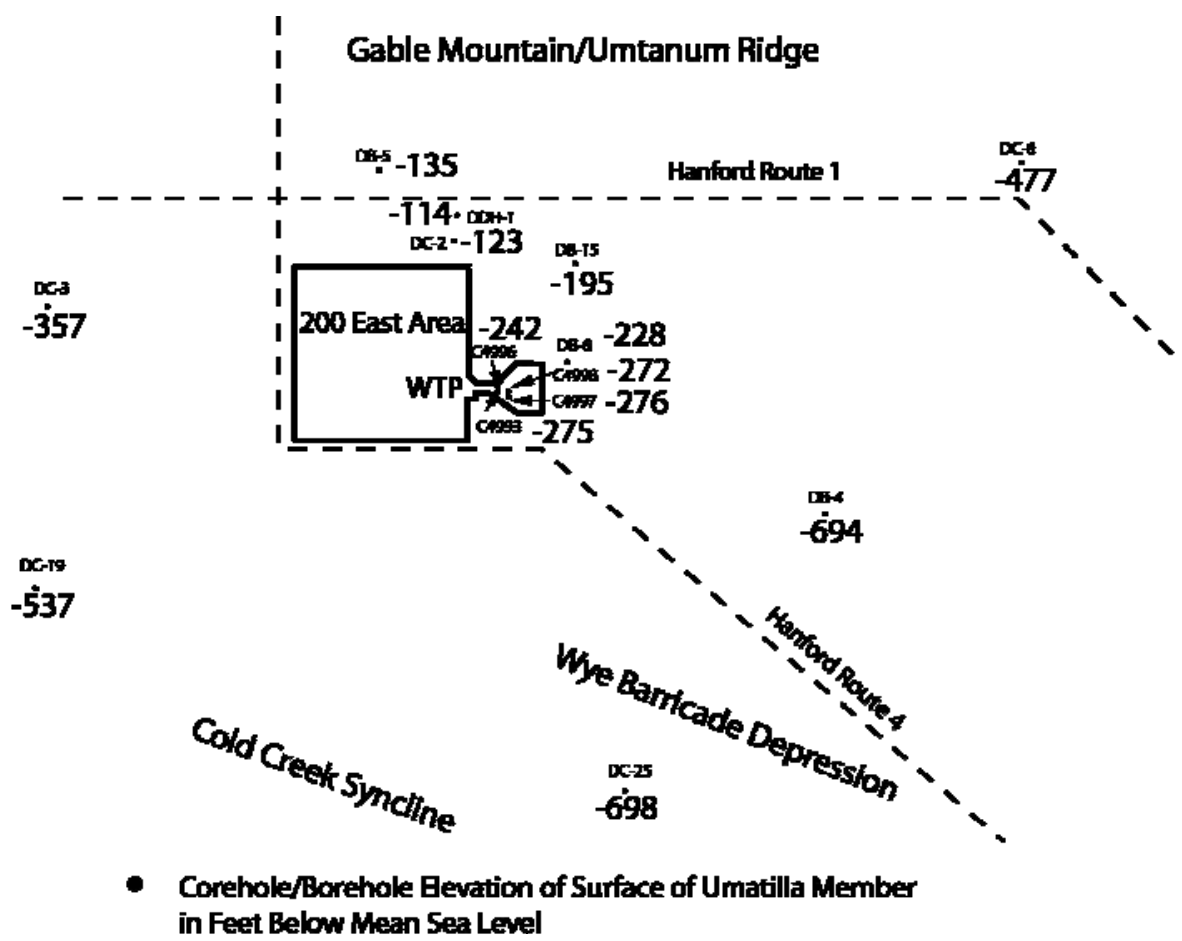

Figure 6.5. Elevation of the Surface of the Umatilla Member in Boreholes near and at the Waste Treatment Plant

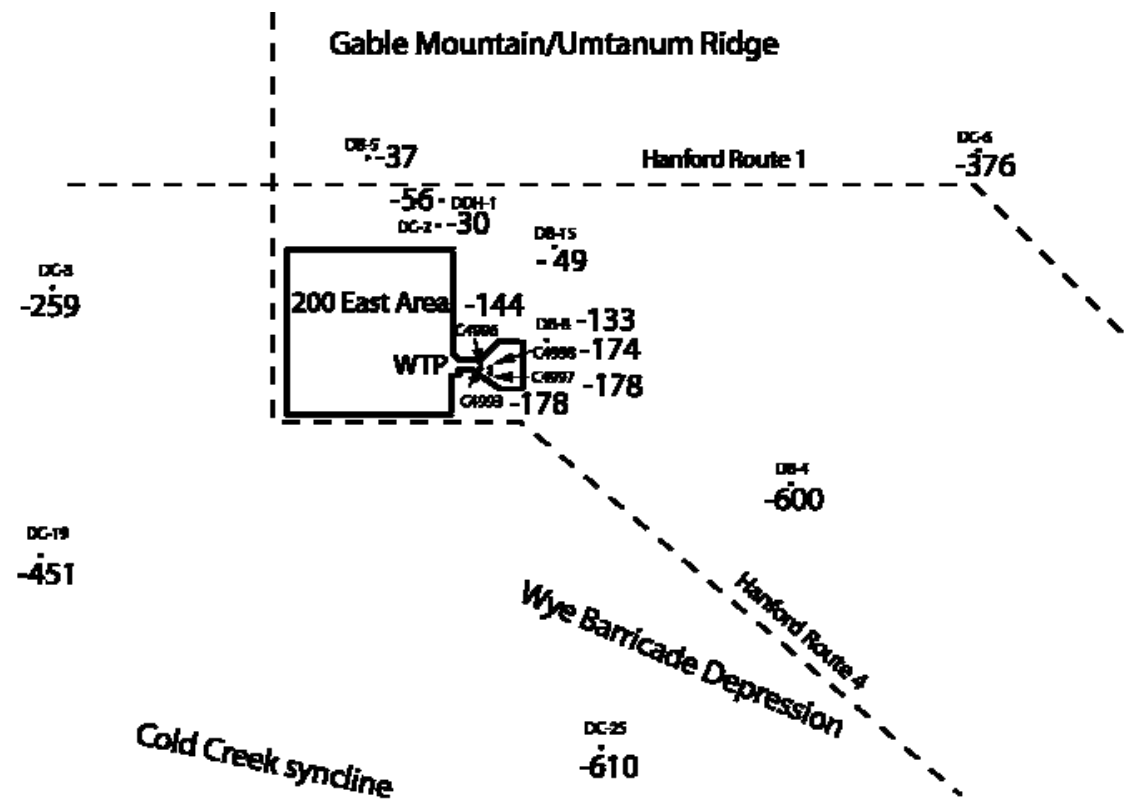

- Corehole/Borehole Elewation of Surface of Cold Creak Interbed In Feet Below Mean Sea Level

Figure 6.6. Elevation of the Surface of the Cold Creek Sedimentary Interbed in Boreholes near and at the Waste Treatment Plant 


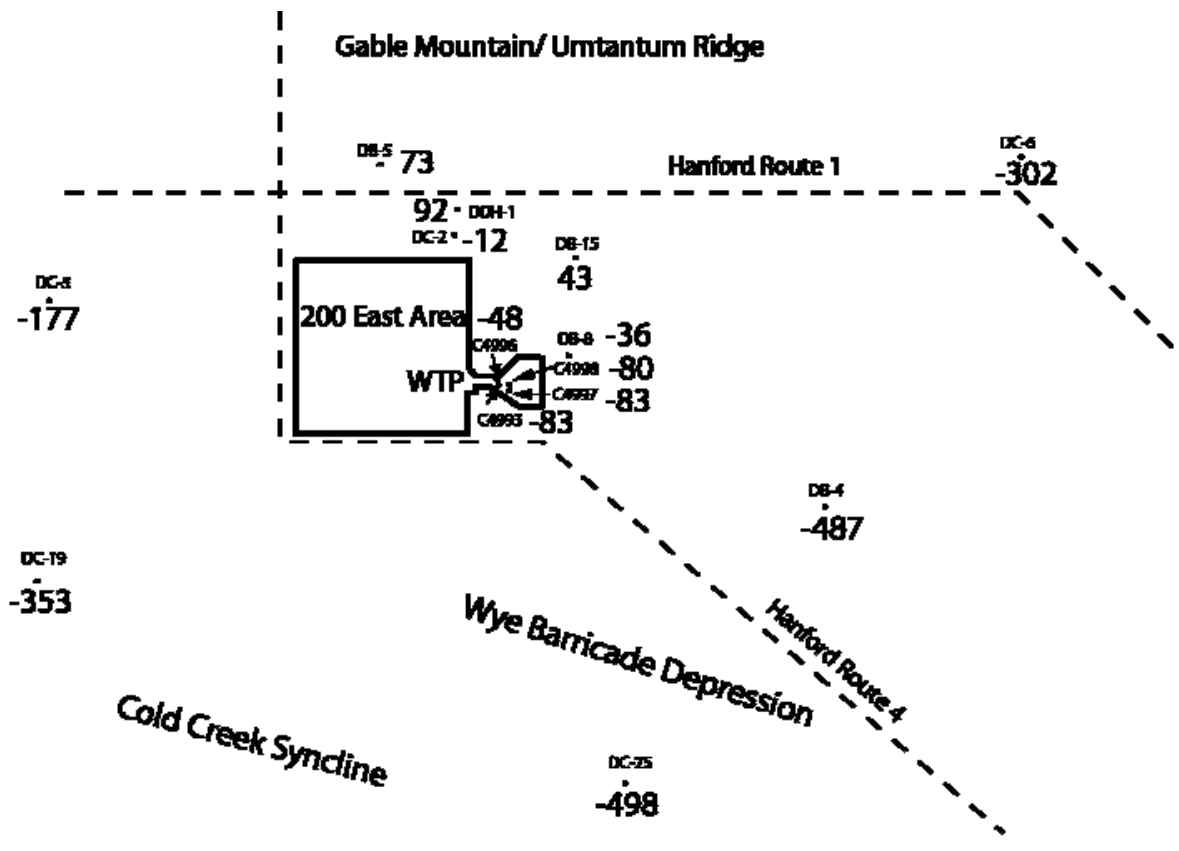

- Corehole/Borehole Elevation of Surface of Esquatzel Member in Feet Above/Below Mean Sea Level

Figure 6.7. Elevation of the Surface of the Esquatzel Member in Boreholes near and at the Waste Treatment Plant

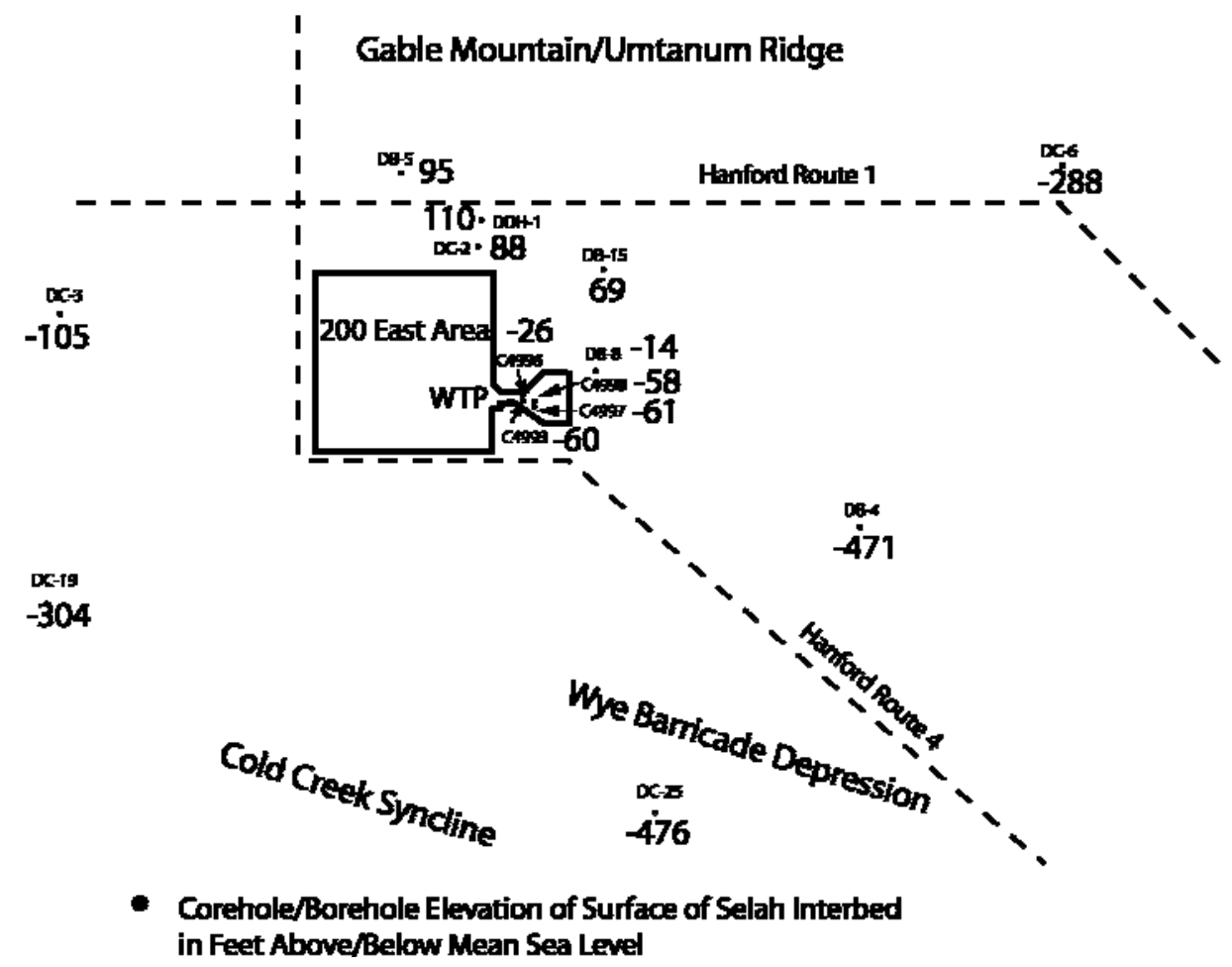

Figure 6.8. Elevation of the Surface of the Selah Sedimentary Interbed in Boreholes near and at the Waste Treatment Plant 


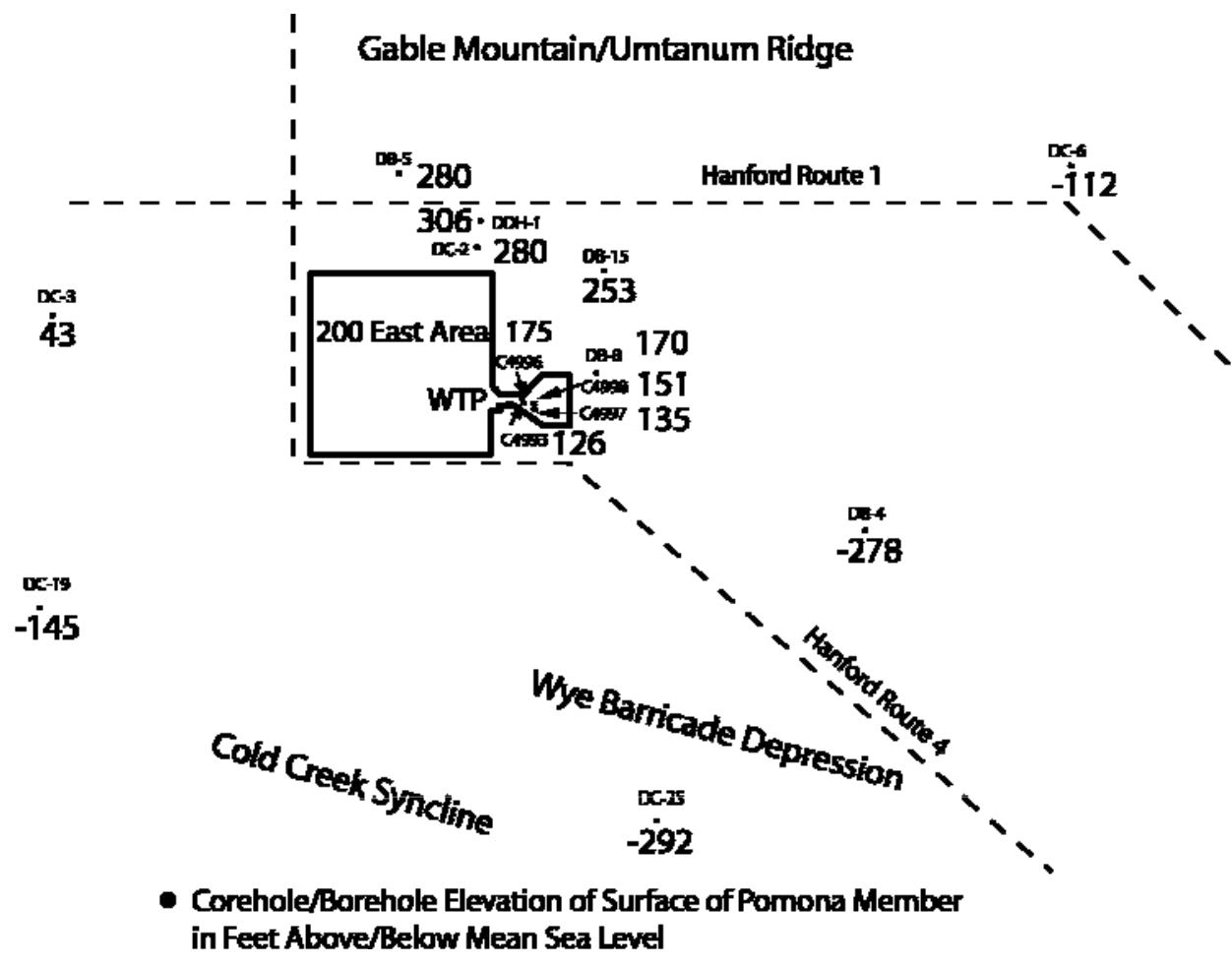

Figure 6.9. Elevation of the Surface of the Pomona Member in Boreholes near and at the Waste Treatment Plant

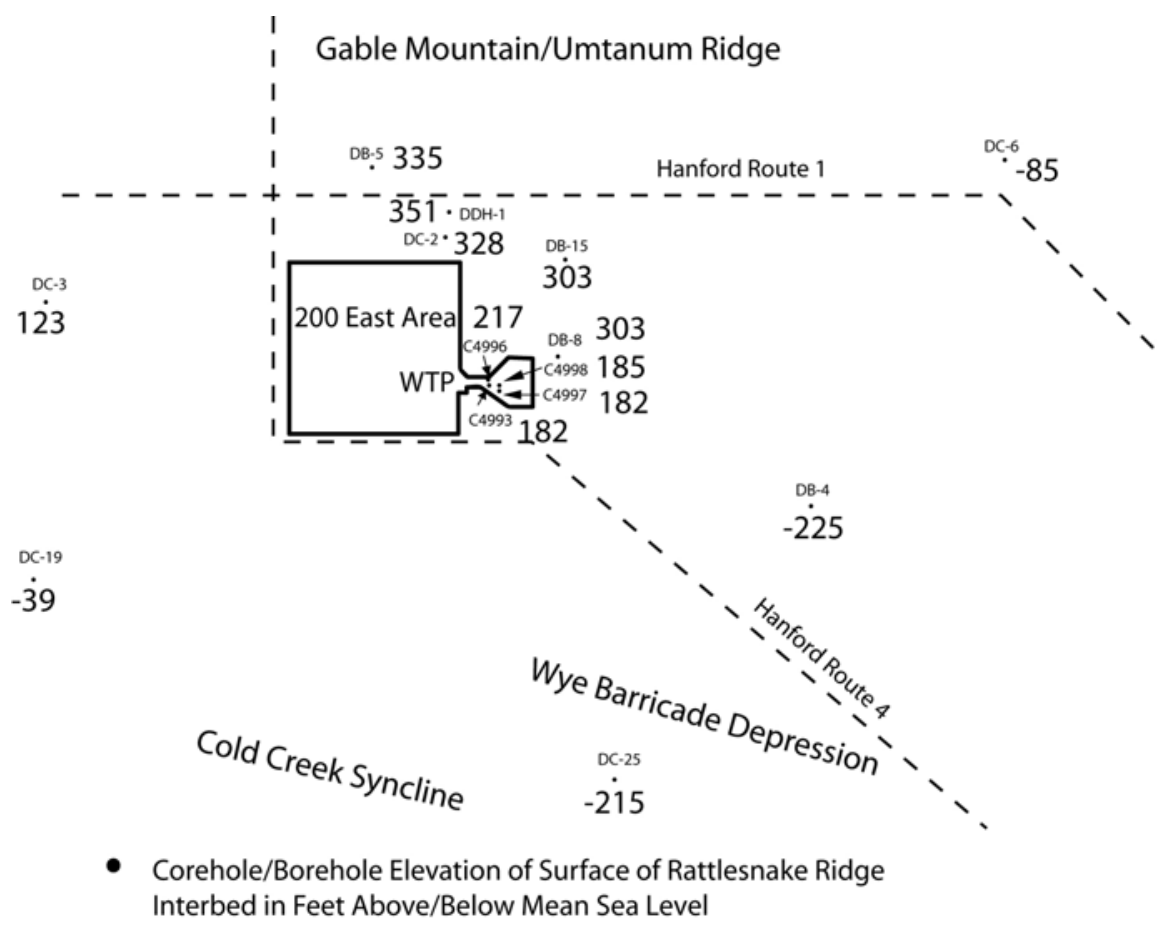

Figure 6.10. Elevation of the Surface of the Rattlesnake Ridge Sedimentary Interbed in Boreholes near and at the Waste Treatment Plant 


\subsection{Fault in Brecciated Flow Top of Pomona Member at the Waste Treatment Plant}

A 10 - to 20 -ft-thick zone of faulting, tectonic brecciation, and shearing was identified in the flow top of the Pomona Member during the logging of the core in borehole C4998. The zone occurs 554 to $564 \mathrm{ft}$ bgs. Pomona Member flow-top breccia was encountered immediately below the Rattlesnake Ridge Interbed at $525.6 \mathrm{ft}$ bgs in core hole $\mathrm{C} 4998$. The flow-top breccia, as defined in Chapter 1, is as follows:

Flow-top breccia occurs as a zone of angular to subrounded, broken volcanic rock fragments that may or may not be supported by a matrix and is located adjacent to the upper contact of the lava flow. A mixture of vesicular and nonvesicular clasts bound by basaltic glass often characterizes the breccia zone. This type of flow top usually forms from a cooled top that is broken up and carried along with the lava flow before it ceases movement. Figure 6.11 is typical flow-top breccia in the Pomona Member in core hole C4998.

The flow-top breccia extends down to $556 \mathrm{ft}$ bgs, where the appearance of the core noticeably changes from breccia clasts mostly having a high degree of vesiculation to clasts with few or no vesicles. In the interval from approximately 556 to $570 \mathrm{ft}$ bgs, the breccia largely gives way to nonbrecciated, competent basalt with relatively few or no vesicles. Accompanying this change is a pattern of high- and low-angle fractures with features indicating displacement along these fractures. Several features are considered as potentially associated with faulting in this zone. These are

- offsets in fractures (directly observable faulting)

- tectonic brecciation

- possible repeated section

- slickensides

- chalcedony vein showing multiple disruptions.

\subsubsection{Offsets in Fractures}

Faulting was first recognized in the offset fractures of Figures 6.12 and 6.13 observed at $558.5 \mathrm{ft}$ bgs. This feature is hosted by nonvesicular, massive basalt and consists of a high-angle $\left(\sim 75^{\circ}\right.$ from horizontal) fracture that is abruptly truncated by a low-angle fault. The high-angle fracture is thicker $(\sim 1 \mathrm{~cm})$ than similar fractures encountered elsewhere in the borehole, and is filled with an unidentified clay.

\subsubsection{Tectonic Breccia}

Brecciation observed in C4998 core is of two general types; primary and tectonic. Primary breccia is flow-top breccia described above and contemporaneous with the deposition of the flow. Tectonic breccia is the result of brittle deformation of competent rock layers, and occurs in the basalt after the flows have cooled and solidified.

Tectonic breccia often may be distinguished from flow-top breccias by certain general characteristics. In contrast with flow-top breccias, tectonic breccias usually contain clasts that are more angular, smaller in size, bounded by sub-parallel fracturing, and are often associated with slickensides (DOE 1988). However, if faulting and shearing is superimposed upon a flow top, some of these criteria may be obscured by the overlapping effects of both types. 
Figures 6.14 through 6.17 show examples of breccias encountered in the fault zone in core hole C4998. These breccias suggest at least a partial tectonic origin. The breccia in Figure 6.14 is found within a dense basalt section and is bound by high-angle fractures. It contains non-vesicular basalt clasts and an opaline matrix differing in appearance and texture from flow-top palagonite and clays.

Figure 6.15 shows a breccia that contains basalt clasts of two distinct colorations and hardness, along with angular clasts of common opal. The breccia in Figure 6.16 is similar to that of Figure 6.15 in that subangular clasts of common opal constitute a prominent component of the breccia. Figure 6.17 shows brecciation on a very limited scale in chalcedony at $561.5 \mathrm{ft}$ bgs. The significance of this re-silicified breccia is that it cross-cuts original depositional textures in the older chalcedony vein. Little or no offset is seen on this small feature, but it reveals brittle destruction of a secondary structure (chalcedony vein) that is subsequently remineralized. It is also connected to a larger breccia zone (see Figure 6.18), which apparently truncates the chalcedony vein (see Section 6.2.5).

\subsubsection{Possible Repeated Section}

Reverse dip-slip movement on a fault within flat-lying strata will often produce an observable repetition of the strata in boreholes. Based on observations of the core from the top of the Pomona Member, there is some suggestion that this may have occurred in C4998. Flow-top breccia with typical chaotic appearance (Figure 6.11, lower part) begins at $526 \mathrm{ft} \mathrm{bgs,} \mathrm{and} \mathrm{continues} \mathrm{downward} \mathrm{uninterrupted}$ to a depth of $556.5 \mathrm{ft}$ bgs. From this depth, down to $560.5 \mathrm{ft}$ bgs, the flow-top materials abruptly disappear, and are replaced by dense, relatively non-vesicular basalt. From 560.5 to $570.3 \mathrm{ft}$ bgs, the pattern repeats, with approximately $5 \mathrm{ft}$ of flow top, or possibly flow top and tectonic breccia mixed, overlying dense basalt. At $570.3 \mathrm{ft}$ bgs the flow-top material resumes until the dense flow interior of the Pomona Member is reached at $590.4 \mathrm{ft}$ bgs. Figure 6.11 shows the core in this sequence in C4998. In addition, the Pomona Member is 15-20 ft thicker in C4998 than predicted for this site and slightly thicker than in boreholes C4993 and C4996. Also, the Rattlesnake Ridge Interbed appears to be substantially thinner in C4998 (34 ft) compared with C4993 and C4996 (56 ft and $42 \mathrm{ft}$, respectively).

\subsubsection{Slickensides}

In distinguishing between flow-top and tectonic breccias, DOE (1988) states "Slickensides are present on some surfaces in tectonic breccias and absent in flow-top breccias without tectonic fracturing." Slickensides are present in joints and fractures in basalt throughout borehole C4998. These may be the result of miniscule movements along joints or faulting. Therefore slickensides are not, taken by themselves, reliable indicators of faulting. They are presented in this discussion as observations that may support but do not prove faulting. An example of slickensides observed in conjunction with the Pomona Member fault zone is shown in Figure 6.19.

\subsubsection{Chalcedony Vein}

The chalcedony vein intercepted at approximately $561 \mathrm{ft}$ bgs is approximately $5 \mathrm{in}$. in apparent thickness and is bounded on top by fractured massive basalt and below by flow top and/or tectonic breccias. The nature of the conduit for the initial emplacement of the chalcedony vein is unknown but is probably the open framework of the flow-top breccia, which is highly permeable. Under magnification (see Figure 6.17), the vein shows colloform banding, indicating either repeated pulses of silica deposition or diffusion banding that may have occurred during a "gel" phase of the vein. 
The chalcedony vein demonstrates episodic disruption or displacement in the fault zone. At least three events are indicated in Figure 6.18. The first event is the emplacement of the chalcedony vein. After solidification of the vein, it is cut by a high-angle, silicified breccia zone apparently containing fragments of the vein. The third event is the truncation of the high-angle breccia zone by a near-vertical fracture with slickensides. Only a relative timing between these events is possible, but the relationships indicate that repeated fracturing events occurred, separated by periods of accumulation or re-cementation of fractures. 


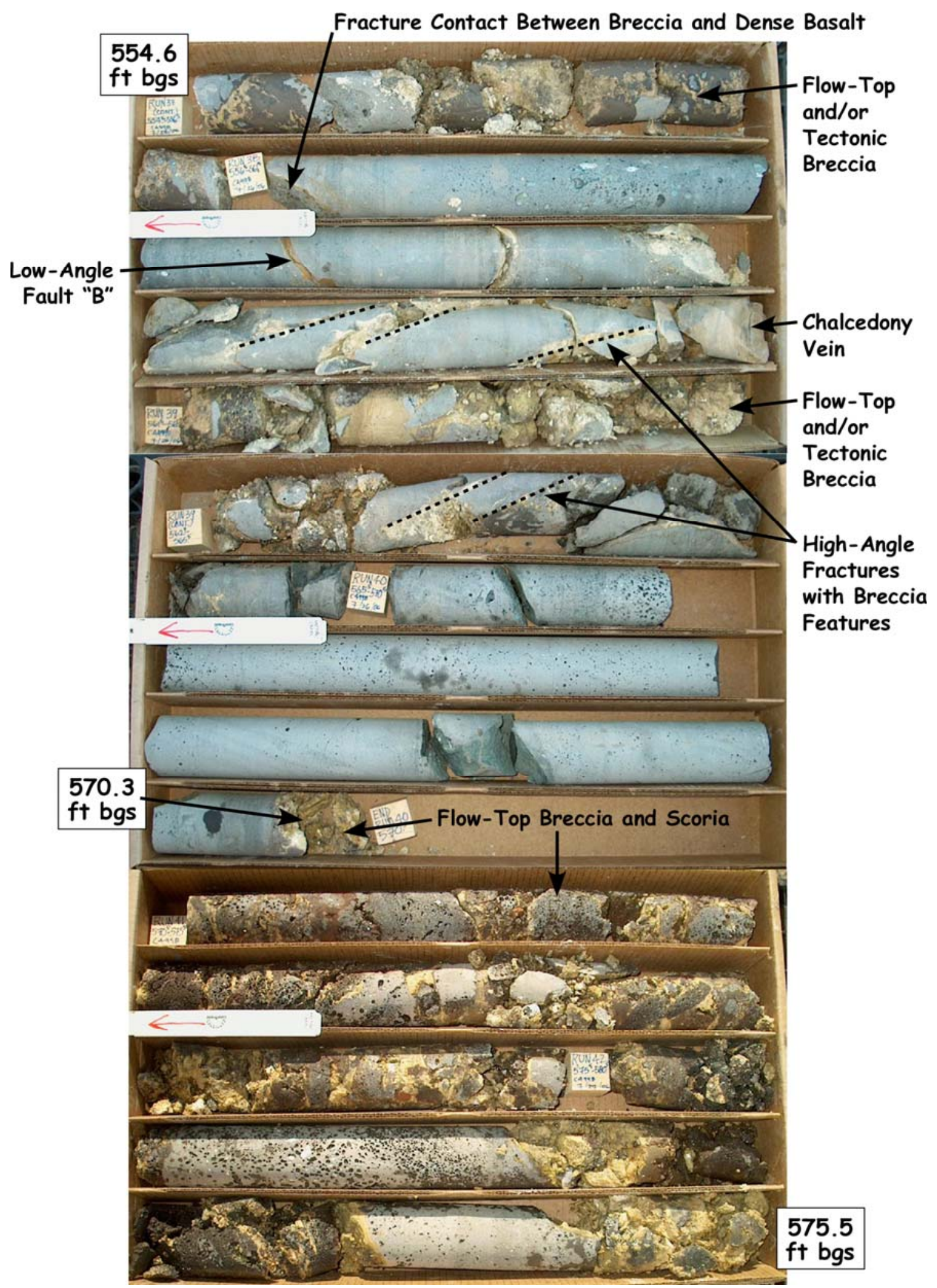

Figure 6.11. Various Features of the Fault Zone in the Pomona Member in Core Hole C4998. The down-hole progression is from left to right and downward in the photos (arrows on the scale indicate the up-hole direction). 


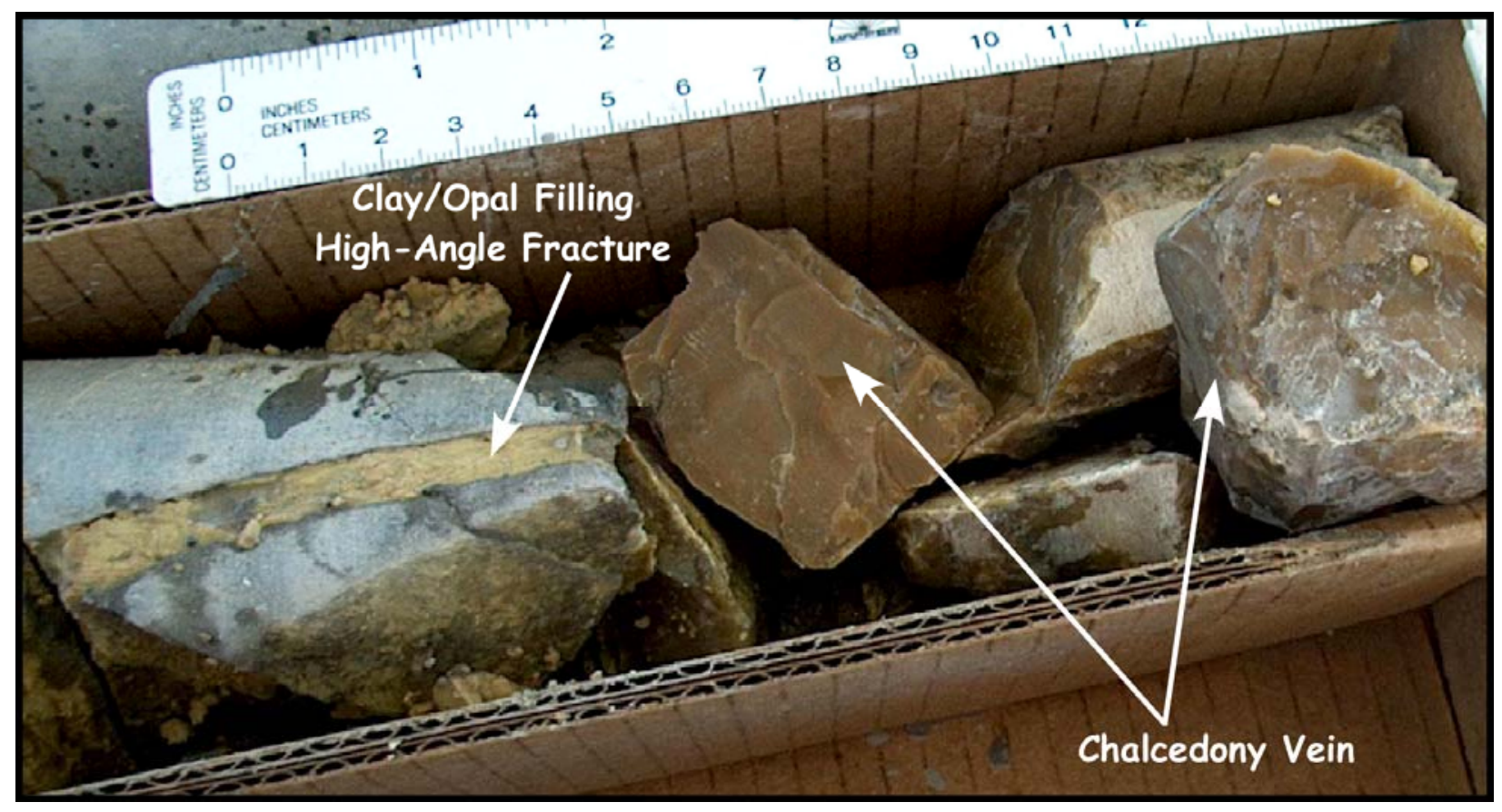

Figure 6.12. Chalcedony and Clay/Opal Veins in Suspected Fault Zone at $561.5 \mathrm{ft}$ bgs in Pomona Member

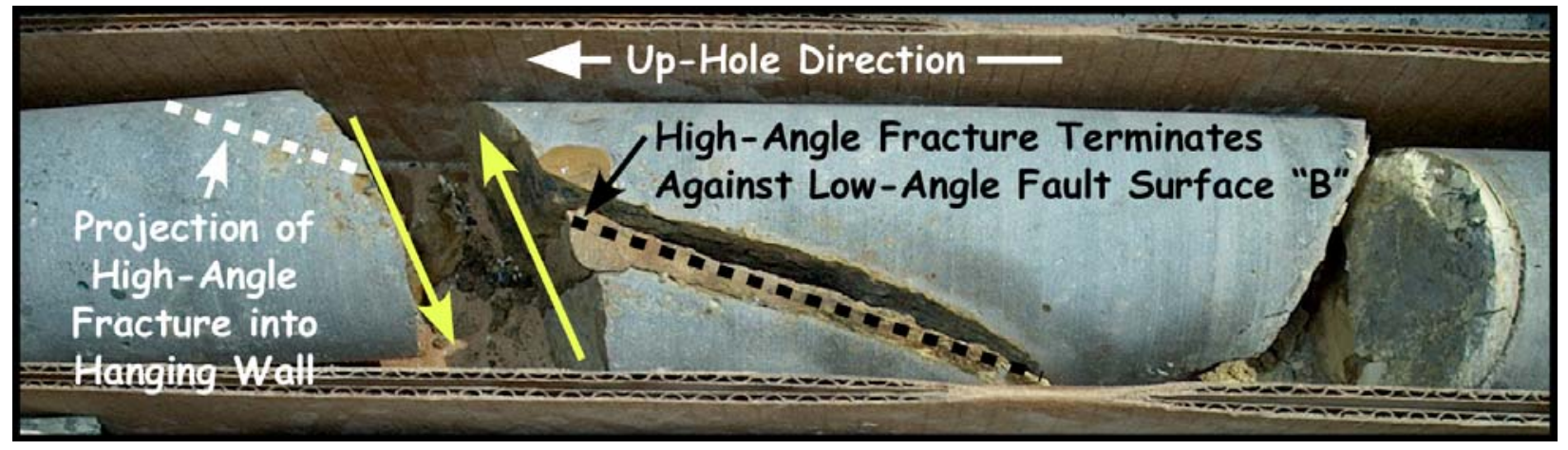

Figure 6.13. Relationships at $558.5 \mathrm{ft}$ bgs Indicating Faulting in the Pomona Member (Basalt). The low-angled fault surface post-dates and offsets the high-angle fracture at right. Yellow arrows denote normal relative movement of the two blocks along the fault plane as indicated by slickensides on both surfaces. The dashed line on the hanging wall core indicates the expected trace of the high-angle fracture if it were not offset by the low-angle fault. 




Figure 6.14. High-Angle Fractures Bounding Basalt Breccia and Opaline Matrix at $563.8 \mathrm{ft}$ bgs in Core Hole C4998 


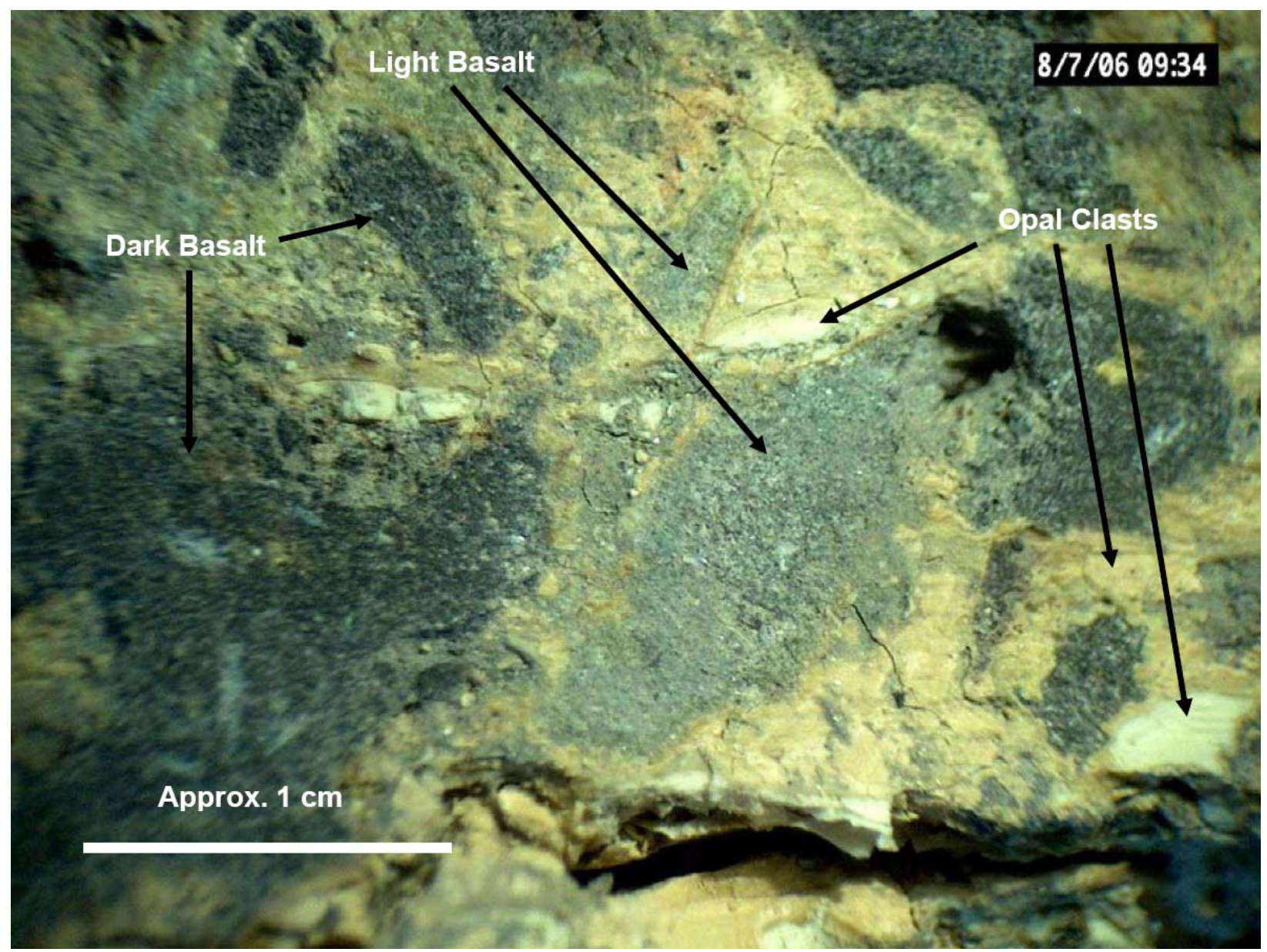

Figure 6.15. Photomicrograph of Brecciation at $545.7 \mathrm{ft}$ bgs in Core Hole C4998 Displaying Two Types of Basalt Clasts and Opaline Clasts. This breccia may be strictly related to the Pomona flow-top emplacement, or be a result of tectonic deformation of flow-top materials. The presence of angular opal clasts might indicate that the structure post-dates flow-top breccia formation. 


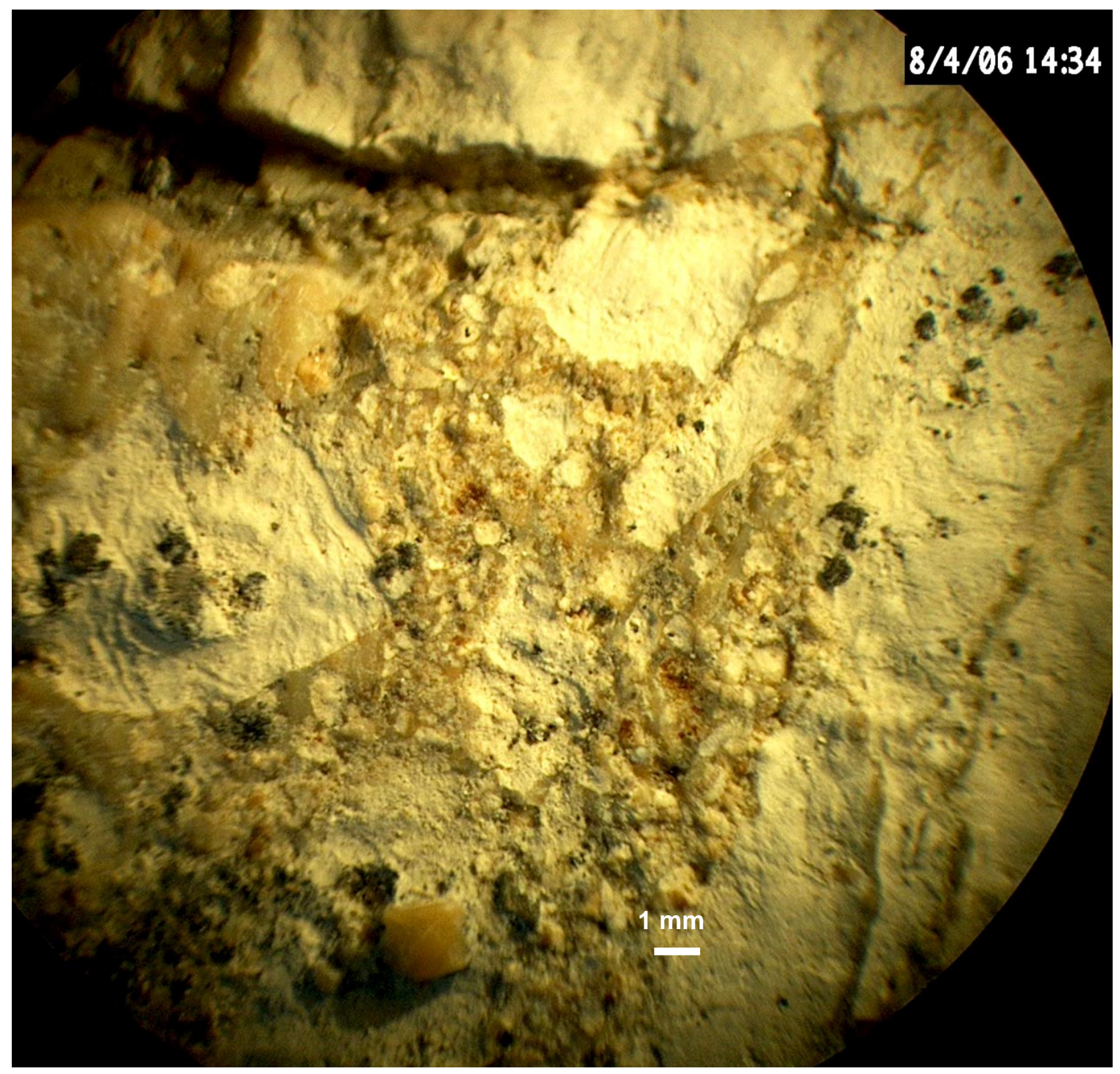

Figure 6.16. Photomicrograph of Brecciation Involving Mostly Clasts of Common Opal. This sample was taken from the same general area as that in Figure 6.15. 


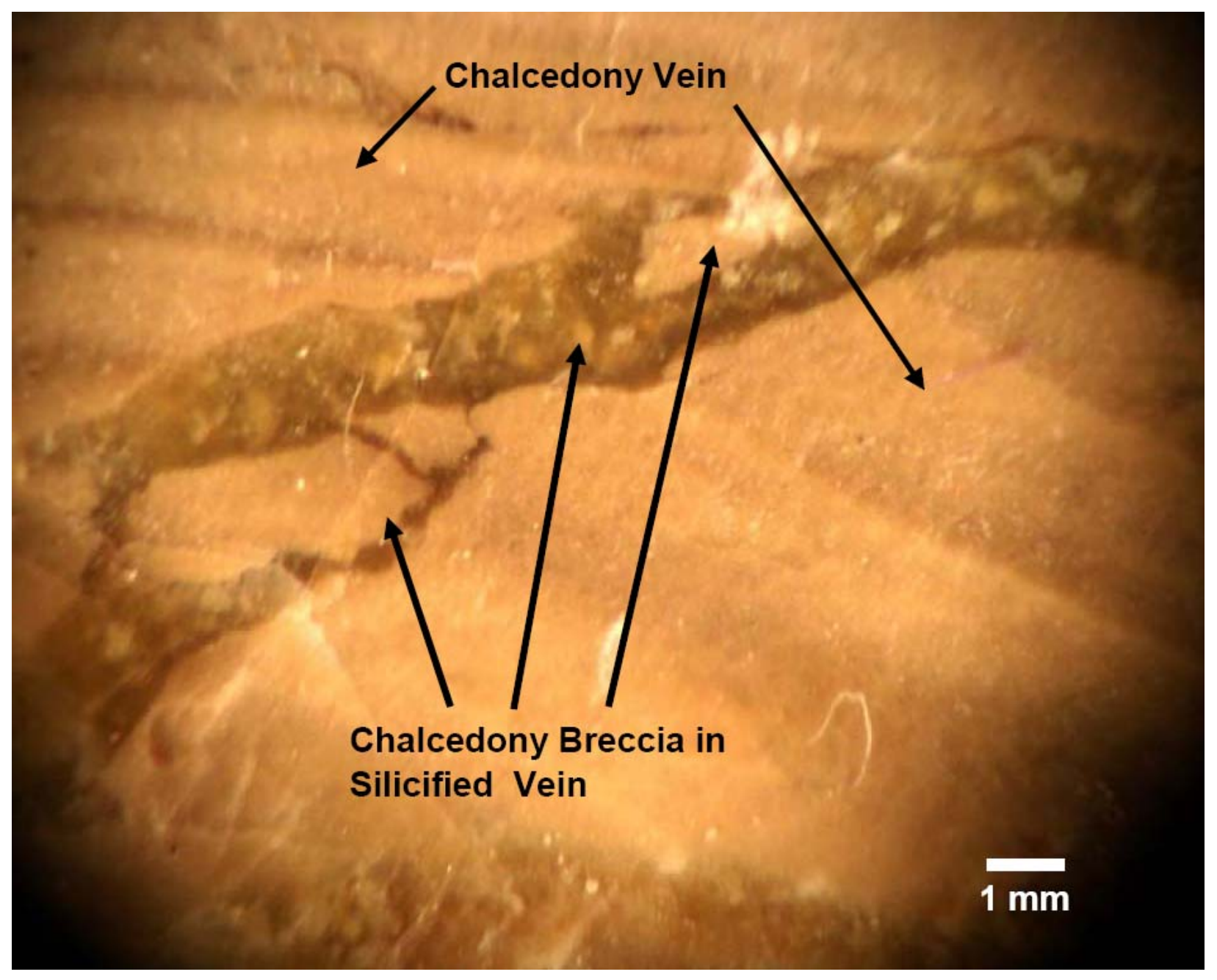

Figure 6.17. Photomicrograph of a Veinlet (Feature A of Figure 6.18) in the Chalcedony Vein Showing Brecciation and Re-silicification at $561.5 \mathrm{ft}$ bgs. Depositional colloform banding in the chalcedony is seen as alternating dark and light bands sloping from upper left to lower right. 


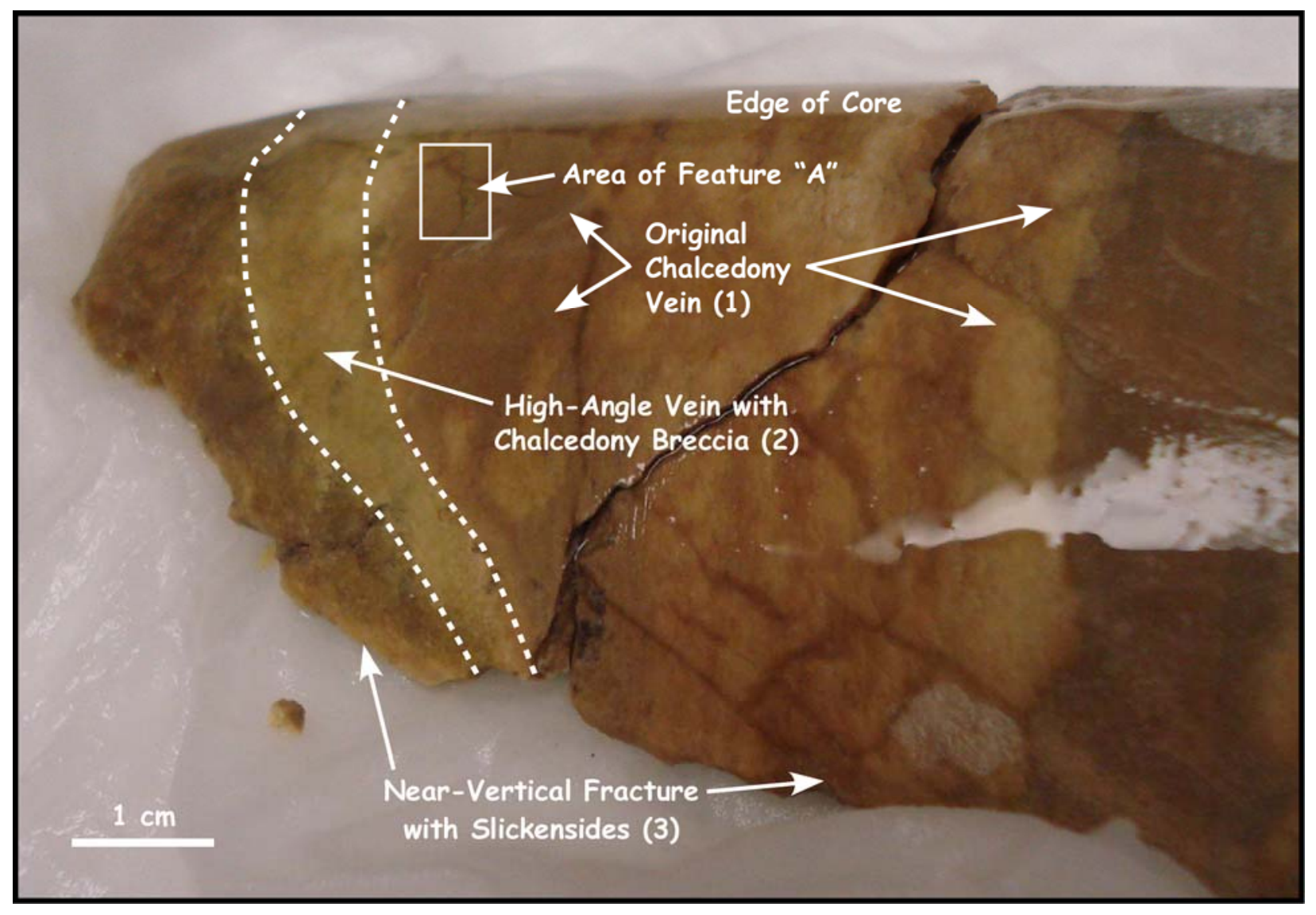

Figure 6.18. The Chalcedony Vein at $561.5 \mathrm{ft}$ bgs in C4998 Core. At least three episodes of deformation are represented by the features shown; the oldest (1) is the emplacement of the chalcedony vein. The chalcedony vein is later cut by a high-angle vein containing breccia fragments of chalcedony, an offshoot of which is seen in Figure 6.17. The high-angle vein is truncated by a near-vertical fault with slickensides. The box indicates the region of the photomicrograph of Figure 6.17. 


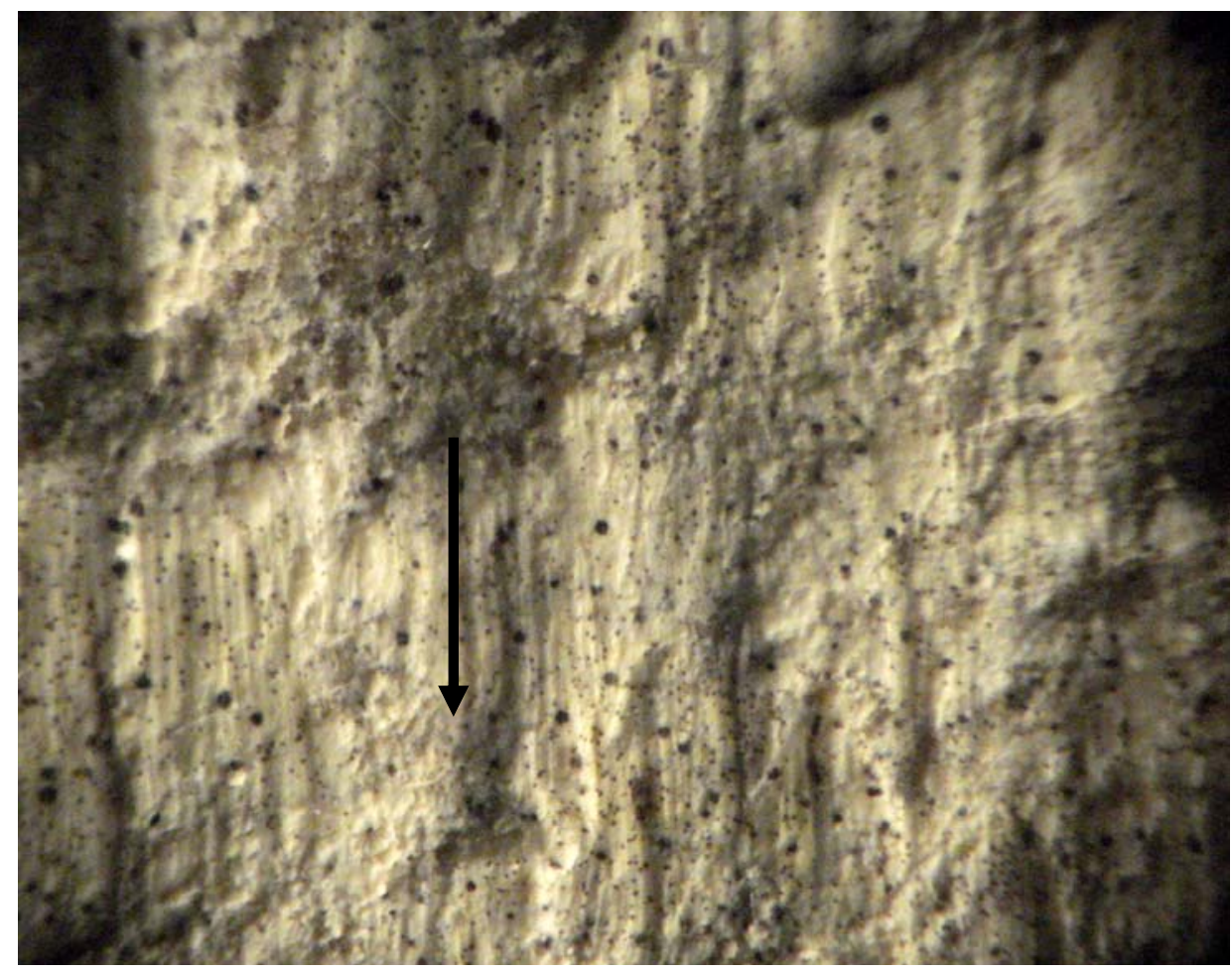

Figure 6.19. Slickensides on the Near-Vertical Fracture in the Chalcedony at $561 \mathrm{ft}$ bgs. The arrow indicates the latest movement of the block relative to the opposing block (i.e., the opposite wall of the fracture not shown). The field of view is approximately $1 \mathrm{~cm}$, side to side. Because of the vertical nature of this fracture, the sense of displacement could not be determined.

\subsection{Nature, Age, and History of Faulting}

Based on the data collected on the fault that penetrated the Pomona Member in core hole C4998, the following can be surmised about the fault:

- The fault is a reverse fault. This conclusion is consistent with the Pomona Member in C4998 being thicker than expected and forming a topographic high.

- The angle and orientation of the fault can not be determined. There are two possible origins for the reverse fault: primary and tectonic.

- Tectonically formed reverse faults are the typical fault found in the Yakima fold belt (DOE 1988). They have formed under north to south oriented regional compression. The most likely orientation for a tectonically formed reverse fault is one with a northwest to southeast strike. A series of small anticlinal domes related to the Umtanum Ridge/Gable Mountain structure occur to the north of WTP and these structures have a northwest to southeast structural trend superimposed on the main east-to-west structural trend of Umtanum Ridge. The fault could have developed along another related and previously unrecognized dome.

- A second possibility is that the reverse fault is a primary feature developed in the flow. Reverse/ thrust faults in the flow top of CRBG lava flows have been observed in the field (Figure 6.20). Primary reverse faults form as the flow top solidifies as the lava flow is still moving. Tumuli, 
which are small domes on the crust of a lava flow caused by pressure due to the difference in rate of flow between cooler crust and more fluid lava below, can form in the flow top. A reverse/ thrust fault develops in the tumulus to accommodate the shortening. If the fault is primary and related to a tumulus, then the orientation can not be predicted based on the available data.

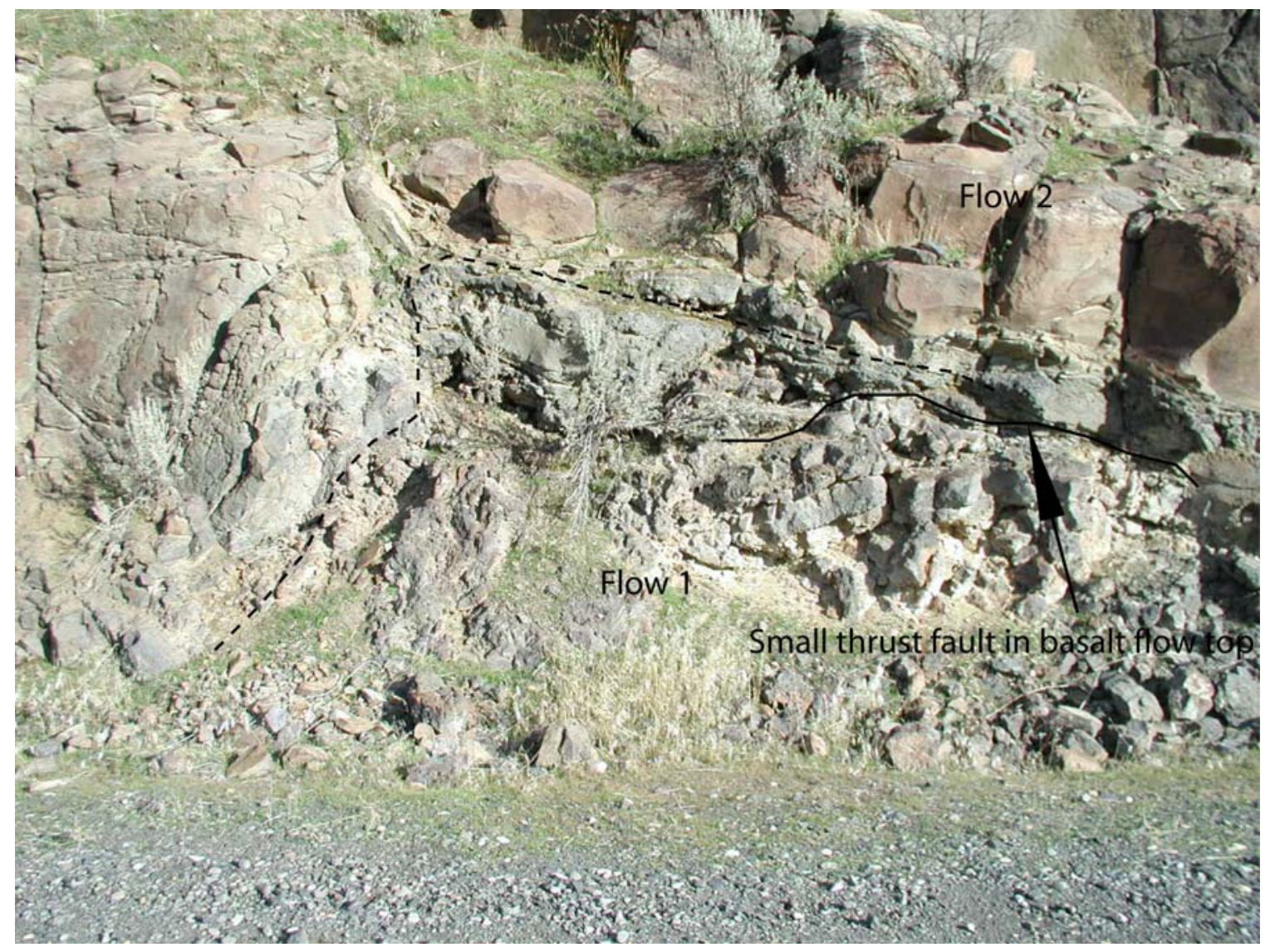

Figure 6.20. Small Reverse/Thrust Fault Developed in the Flow Top of an Elephant Mountain Member Flow

- There are 15 to $20 \mathrm{ft}$ of extra thickness in the Pomona Member than predicted based on nearby boreholes; this appears to be the result of a repeated stratigraphy in the flow-top breccia. This is consistent with the topographic high being caused by a reverse fault but tells little of the fault's origin or age.

- The Rattlesnake Ridge Interbed thins over the topographic high in the Pomona Member compared to nearby boreholes. This is consistent with the topographic high developing before or during the deposition of the Rattlesnake Ridge Interbed.

- The flow-top breccia and fault have been filled with secondary minerals, mainly common opal. Silica, the building block of common opal, does not dissolve easily in cold water. The solubility of silica increases in water, however, as the temperature rises. A scenario that could explain the abundance of common opal and chalcedony in the flow-top breccia and fault is first by solution of silica in hot water with the emplacement of the Elephant Mountain Member as the heat source. Water and silica are derived from the Rattlesnake Ridge Interbed. Silica is then circulated in groundwater 
through the Pomona flow top. Deposition of silica as chalcedony occurs as the water temperature is lowered as it comes in contact with the much cooler (1.5 million years older) Pomona flow top.

- There are three generations of structures defined by secondary minerals as typified by the chalcedony vein. The first is the initial deposition of chalcedony (or other secondary minerals). The second event is the brecciation and re-cementation (by chalcedony) of the original chalcedony vein. The final deformation is recognized by slickensides on the second generation of chalcedony. The two generations of chalcedony suggest a source of heat is present. The last deformation does not require a heat source. The deformation of the first and second generations of chalcedony could have occurred while the 10.5-million-year-old Elephant Mountain Member was cooling to ambient temperature. The last recognized deformation could have occurred after the Elephant Mountain Member had cooled. How long after is unknown.

- The lowest of the three Rattlesnake Ridge Interbed facies was deposited in the area surrounding the topographic high on the Pomona surface created by the fault. The upper two facies of the Rattlesnake Ridge Interbed in core hole C4998 are of similar thicknesses as surrounding boreholes (Figure 5.9). This suggests that the main movement on the fault occurred prior to the deposition of the middle and upper facies of the Rattlesnake Ridge Interbed and the 10.5-million-year-old Elephant Mountain Member.

\subsection{Conclusions About the Fault}

Although data are limited, the fault encountered in C4998 is a reverse fault. It has a small amount of offset (15-20 ft of vertical offset depending on the dip of the fault plane); horizontal displacement is not known but, based on field observations in the Yakima Fold Belt, is probably comparable to the vertical offset. The age of last movement is not known, but based on the overlying Rattlesnake Ridge Interbed, the fault formed shortly after the 12-million-year-old Pomona flow was emplaced and most of the movement occurred prior to the emplacement of the 10.5-million-year-old Elephant Mountain Member. This is not surprising because the current structural topography of the Hanford Site has developed since emplacement of the Elephant Mountain Member. The Elephant Mountain Member caps all the anticlinal ridges in the Pasco Basin and has been folded and faulted throughout the Yakima Fold Belt. 


\subsection{References}

Adams SC, ST Ahlquist, JR Fetters, BJ Garcia, and CF Rust. 2007. Borehole Summary Report for Waste Treatment Plant Seismic Borehole C4996. WMP-32076, Fluor Hanford, Inc., Richland, Washington.

Barnett DB and BJ Garcia. 2006. Borehole Summary Report for Core Hole C4998 - Waste Treatment Plant Seismic Boreholes Project. PNNL-16303, Pacific Northwest National Laboratory, Richland, Washington.

Bjornstad BN. 2006. On the Trail of the Ice Age Floods: A Geological Field Guide to the Mid-Columbia Basin. Keokee Publishing Co., Inc, Sandpoint, Idaho.

Camp VE, ME Ross, and WE Hanson. 2003. "Genesis of Flood Basalts and Basin and Range Volcanic Rocks from Steens Mountain to the Malheur River Gorge, Oregon.” GSA Bulletin 115(1):105-128.

DiFebbo T. 2007. Borehole Summary Report for C4997 Rotary Drilling, WTP Seismic Boreholes Project. WMP-31815, Fluor Hanford, Inc., Richland, Washington.

DOE. 1988. Consultation Draft Site Characterization Plan, Reference Repository Location, Hanford Site, Washington. DOE/RW-0164, Volume 1 of 9. U.S. Department of Energy, Office of Civilian Radioactive Waste Management, Washington, D.C.

DOE-RL. 2002. Standardized Stratigraphic Nomenclature for the Post-Ringold-Formation Sediments within the Central Pasco Basin. DOE/RL-2002-39, U.S. Department of Energy Richland Operations Office, Richland, Washington.

Fecht KR, SP Reidel, and AM Tallman. 1987. "Paleodrainage of the Columbia River System on the Columbia Plateau of Washington State-A Summary." In Selected Papers on the Geology of Washington, ed. J. E. Schuster, Division of Geology and Earth Resources, Bulletin 77, pp. 219-248, Washington State Department of Natural Resources, Olympia, Washington.

Gardner MG and RK Price. 2007. Summary Report of Geophysical Logging for the Seismic Boreholes Project at the Hanford Site Waste Treatment Plant. DTS-RPT-090, EnergySolutions, Inc., Richland, Washington.

Hon K, J Kauahikaua, R Denlinger, and K Mackay. 1994. "Emplacement and Inflation of Pahoehoe Sheets Flows - Observations and Measurements of Active Lava Flows on Kilauea Volcano, Hawaii." Geological Society of America Bulletin 106:351-370.

Horner JA. 2007. Entry Boreholes Summary Report for the Waste Treatment Plant Seismic Boreholes Project. WMP-32119, Fluor Hanford, Inc., Richland, Washington.

Lindsey KA. 1995. Miocene- to Pliocene-Aged Suprabasalt Sediments of the Hanford Site, SouthCentral Washington. BHI-00184, Bechtel Hanford, Inc., Richland, Washington. 
Lindsey KA. 1996. Miocene-Pliocene Ringold Formation and Associated Deposits of the Ancestral Columbia River System, South-Central Washington and North-Central Oregon. Washington Department of Natural Resources, Division of Geology and Earth Resources Open-File Report 96-8, Olympia, Washington.

McMillian KC, PE Long, and RW Cross. "Vesiculation in Columbia River Basalts." In Volcanism and Tectonism in the Columbia River Flood Basalt Province, SP Reidel and PR Hooper (eds.), Special Paper 239, pp. 157-168, Geological Society of America, Boulder, Colorado.

Reidel SP. 1998. "Emplacement of Columbia River Flood Basalt." Journal of Geophysical Research B 103(B11):27, 393-27, 410.

Reidel SP and KR Fecht. 1981. "Wanapum and Saddle Mountains Basalts of the Cold Creek Syncline Area." In Subsurface Geology of the Cold Creek Syncline, CW Myers and SM Price (eds.), RHO-BWIST-14, Rockwell Hanford Operations, Richland, Washington.

Reidel SP, KR Fecht, KA Lindsey, and NP Campbell. 1994. Late Cenozoic Structure and Stratigraphy of South-Central Washington. Bulletin 80, Washington Division of Geology and Earth Resources, Washington State Department of Natural Resources, Olympia, Washington.

Reidel SP, TL Tolan, PR Hooper, MH Beeson, KR Fecht, RD Bentley, and JL Anderson. 1989. "The Grande Ronde Basalt, Columbia River Basalt Group - Stratigraphic Descriptions and Correlations in Washington, Oregon, and Idaho." In Volcanism and Tectonism in the Columbia River Flood-Basalt Province, SP Reidel and PR Hooper (eds.), Special Paper 239, pp. 21-53, Geological Society of America, Boulder, Colorado.

Rust CF, DB Barnett, NA Bowles, and JA Horner. 2007. Borehole Summary Report for Waste Treatment Plant Seismic Borehole C4993. PNNL-16343, Pacific Northwest National Laboratory, Richland, Washington.

Self S, L Keszthelyi, and T Thordarson. 1997. "The Importance of Pahoehoe.” Annual Review of Earth Planetary Science 26:81-110.

Swanson DA, TL Wright, PR Hooper, and RD Bentley. 1979. Revisions in Stratigraphic Nomenclature of the Columbia River Basalt Group. Bulletin 1457-G, U.S. Geological Survey, Washington, D.C.

Swanson DA, TL Wright, VE Camp, JN Gardner, RT Helz, SM Price, SP Reidel, and ME Ross. 1980. Reconnaissance Geologic Map of the Columbia River Basalt Group, Pullman and Walla Walla Quadrangles, Southeast Washington and Adjacent Idaho. Miscellaneous Investigations Series Map I-1139, U.S. Geological Survey, Denver, Colorado.

Thordarson T and S Self. 1998. "The Roza Member, Columbia River Basalt Group-A Gigantic Pahoehoe Lava Flow Field Formed by Endogenous Processes?" Journal of Geophysical Research 103(B11):27, 411-27, 445.

Tomkeieff SI. 1940. “The Basalt Lavas of the Giant's Causeway District of Northern Ireland." Bulletin of Volcanology 6:89-143. 
Walker GPL, E Canon-Tapia, and E Harrero-Bervera. 1999. "Origin of Vesicle Layering and Double Imbrication by Endogenous Growth in the Birkett Basalt Flow." Journal of Volcanology and Geothermal Research 88:15-28.

Waters AC. 1961. "Stratigraphic and Lithologic Variations in the Columbia River Basalt." American Journal of Science 259:583-611. 


\section{Appendix A}

Compositions of Selected Saddle Mountains Basalt and Wanapum Basalt Flow 


\section{Appendix A}

\section{Compositions of Selected Saddle Mountains Basalt and Wanapum Basalt Flow}

Table A.1 is a listing of compositions of selected Columbia River Basalt Group (CRBG) flows obtained by the Basalt Waste Isolation Project. The compositions of CRBG lava flows are well established, and this table summarizes typical compositions. These analyses were performed by Washington State University's GeoAnalytical Laboratory. The samples were collected from Basalt Waste Isolation Project core from the Hanford Site. 
MAJOR OXIDES (weight per cent)

Formation

Member

Saddle Mountains Basalt Elephant Mtn

Saddle Mountains Basalt Elephant Mtn.

Saddle Mountains Basalt Elephant Mtn.

Saddle Mountains Basalt Pomon

Saddle Mountains Basalt Pomona

Saddle Mountains Basalt Pomona

Saddle Mountains Basalt Esquatzel

Saddle Mountains Basalt Umatilla, basalt of Sillusi.

Saddle Mountains Basalt Umatilla, basalt of Sillusi.

Saddle Mountains Basalt Umatilla, basalt of Sillusi.

Saddle Mountains Basalt Umatilla, basalt of Umatilla

Saddle Mountains Basalt Umatilla, basalt of Umatilla

Saddle Mountains Basalt Umatilla, basalt of Umatilla

Wanapum Basalt $\quad$ Priest Rapids, basalt of Lolo

Wanapum Basalt $\quad$ Priest Rapids, basalt of Lolo

Wanapum Basalt Priest Rapids, basalt of Lolo

Wanapum Basalt $\quad$ Priest Rapids, basalt of Rosalia

Wanapum Basalt

Priest Rapids, basalt of Rosalia

Wanapum Basalt

Priest Rapids, basalt of Rosalia

Wanapum Basal

Wanapum Basalt

Wanapum B

Roza

Roza

Roza

Roza

\begin{tabular}{|c|c|c|c|c|c|}
\hline $\mathrm{SiO} 2$ & $\mathrm{TiO} 2$ & $\mathrm{Al} 2 \mathrm{O} 3$ & $\mathrm{FeO}^{*}$ & $\mathrm{MnO}$ & $\mathrm{CaO}$ \\
\hline$=$ & $=$ & $=$ & $=$ & $=$ & $=$ \\
\hline 52.14 & 3.484 & 12.86 & 14.70 & 0.215 & 8.56 \\
\hline 51.51 & 3.381 & 13.18 & 14.79 & 0.219 & 8.53 \\
\hline 51.43 & 3.505 & 13.23 & 14.36 & 0.206 & 8.70 \\
\hline 54.90 & 1.606 & 14.51 & 10.41 & 0.168 & 9.93 \\
\hline 53.20 & 1.635 & 14.51 & 10.61 & 0.175 & 10.43 \\
\hline 54.39 & 1.694 & 14.19 & 10.90 & 0.192 & 8.68 \\
\hline 54.40 & 3.026 & 13.26 & 13.34 & 0.188 & 7.62 \\
\hline 53.81 & 3.083 & 13.09 & 13.61 & 0.192 & 7.54 \\
\hline 54.72 & 2.670 & 13.63 & 12.12 & 0.195 & 6.51 \\
\hline 55.45 & 2.700 & 13.77 & 11.98 & 0.172 & 6.27 \\
\hline 55.35 & 2.589 & 13.82 & 11.91 & 0.162 & 6.27 \\
\hline 53.55 & 3.160 & 13.53 & 13.12 & 0.300 & 6.84 \\
\hline 53.81 & 3.130 & 13.51 & 12.78 & 0.201 & 6.75 \\
\hline 53.94 & 3.120 & 13.75 & 12.54 & 0.188 & 6.68 \\
\hline 50.58 & 2.632 & 13.41 & 13.97 & 0.230 & 9.44 \\
\hline 49.88 & 3.011 & 13.57 & 13.97 & 0.229 & 9.81 \\
\hline 50.64 & 3.249 & 13.42 & 14.32 & 0.241 & 9.36 \\
\hline 50.40 & 3.533 & 12.97 & 14.82 & 0.239 & 8.91 \\
\hline 49.99 & 3.595 & 12.74 & 14.85 & 0.242 & 9.32 \\
\hline 49.82 & 3.300 & 14.15 & 12.67 & 0.210 & 10.31 \\
\hline 51.10 & 3.270 & 13.43 & 13.94 & 0.224 & 8.65 \\
\hline 51.19 & 3.240 & 13.31 & 14.20 & 0.222 & 8.52 \\
\hline 51.07 & 3.260 & 13.35 & 14.13 & 0.228 & 8.56 \\
\hline & 3.280 & 13.42 & 13.97 & 0.240 & \\
\hline
\end{tabular}

TRACE ELEMENTS (ppm)

\begin{tabular}{|c|c|c|c|c|c|c|c|c|c|c|c|c|}
\hline $\begin{array}{l}\mathrm{MgO} \\
=\end{array}$ & $\begin{array}{l}\mathrm{K} 2 \mathrm{O} \\
=\end{array}$ & $\begin{array}{l}\mathrm{Na} 2 \mathrm{O} \\
=\end{array}$ & $\begin{array}{l}\mathrm{P} 2 \mathrm{O} 5 \\
=\end{array}$ & $\begin{array}{l}\text { TOTAL } \\
=\end{array}$ & $\begin{array}{l}\mathrm{Ni} \\
=\end{array}$ & $\begin{array}{l}\mathrm{Cr} \\
=\end{array}$ & $\begin{array}{l}\text { Sc } \\
=\end{array}$ & $\begin{array}{l}\mathrm{V} \\
=\end{array}$ & $\begin{array}{l}\mathrm{Rb} \\
=\end{array}$ & $\begin{array}{l}\mathrm{Ba} \\
=\end{array}$ & $\begin{array}{l}\mathrm{Sr} \\
=\end{array}$ & $\begin{array}{l}\mathrm{Zr} \\
=\end{array}$ \\
\hline 4.10 & 1.12 & 2.26 & 0.552 & 99.99 & 11 & 21 & 34 & 393 & 31 & 471 & 235 & 234 \\
\hline 13 & 1.28 & 2.43 & 0.530 & 99.98 & 10 & 34 & 33 & 398 & 32 & 452 & 234 & 238 \\
\hline .02 & 1.40 & 2.60 & 0.555 & 100.01 & 14 & 41 & 33 & 399 & 32 & 573 & 243 & 46 \\
\hline 41 & 0.81 & 2.53 & 0.240 & 101.51 & 36 & 93 & 25 & 266 & 21 & 277 & 234 & 38 \\
\hline 90 & 0.73 & 2.48 & 0.229 & 100.90 & 40 & 99 & 27 & 278 & 16 & 245 & 228 & 35 \\
\hline 70 & 1.15 & 3.01 & 0.287 & 99.19 & 15 & 50 & 36 & 301 & 33 & 500 & 308 & 57 \\
\hline 84 & 1.65 & 3.00 & 0.408 & 100.73 & 3 & 13 & 19 & 347 & 47 & 576 & 258 & 08 \\
\hline 81 & 1.71 & 3.02 & 0.408 & 100.27 & 0 & 14 & 21 & 365 & 44 & 591 & 257 & 12 \\
\hline .73 & 2.89 & 3.56 & 0.970 & 100.00 & 0 & 8 & 30 & 147 & 50 & 3401 & 282 & 49 \\
\hline 33 & 2.65 & 3.69 & 0.980 & 99.99 & & 10 & & 153 & 39 & 3475 & 283 & 152 \\
\hline 29 & 2.81 & 3.78 & 1.030 & 100.01 & ( & 14 & 31 & 139 & 36 & 3641 & 289 & 464 \\
\hline 87 & 2.60 & 3.24 & 0.790 & 100.00 & 0 & 14 & 3 & 25 & 46 & 2731 & 286 & 95 \\
\hline 18 & 2.59 & 3.28 & 0.780 & 100.01 & & 19 & & 252 & 48 & 2743 & 280 & 408 \\
\hline .98 & 2.43 & 3.56 & 0.810 & 100.00 & 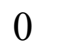 & 13 & 30 & 245 & 43 & 2849 & 279 & 412 \\
\hline .74 & 0.97 & 2.68 & 0.725 & 100.38 & 33 & 99 & 41 & 32 & 25 & 510 & 290 & 81 \\
\hline 5.42 & 1.11 & 2.79 & 0.729 & 100.52 & 36 & 102 & 39 & 348 & 29 & 506 & 272 & 180 \\
\hline 5.12 & 1.01 & 2.72 & 0.763 & 100.84 & 29 & 93 & 39 & 363 & 27 & 505 & 283 & 184 \\
\hline 36 & 1.11 & 2.87 & 0.820 & 100.03 & 7 & 25 & 44 & 42 & 21 & & 301 & 23 \\
\hline .61 & 1.13 & 2.87 & 0.763 & 100.11 & 6 & 25 & 42 & 406 & 25 & 567 & 291 & 207 \\
\hline .83 & 1.10 & 2.83 & 0.770 & 99.99 & 27 & 97 & 44 & 364 & 23 & 483 & 310 & 79 \\
\hline 40 & 1.32 & 2.95 & 0.710 & & 10 & 36 & 38 & & 33 & 545 & & \\
\hline 39 & 1.43 & 2.79 & 0.700 & 99.99 & 7 & 35 & 43 & 416 & 34 & 576 & 308 & 191 \\
\hline 43 & 1.34 & 2.94 & 0.700 & 100.01 & 6 & 33 & 47 & 412 & 32 & 553 & 305 & 191 \\
\hline 20 & 1.49 & 2.83 & 0.720 & 100.00 & 8 & 31 & 42 & 424 & 34 & 544 & 309 & \\
\hline
\end{tabular}




\section{Appendix B}

Compositions of Basalt from Waste Treatment Plant Boreholes 


\section{Appendix B}

\section{Compositions of Basalt from Waste Treatment Plant Boreholes}

The analyses listed in Table B.1 were done at the GeoAnalytical Laboratory at Washington State University. The basalt samples were analyzed by the x-ray fluorescence technique. These analyses were performed to provide supplemental qualitative characterization information on basalt samples from beneath the Waste Treatment Plant. The analytical data have been determined to be non-quality affecting. Therefore, Pacific Northwest National Laboratory standard laboratory practices and procedures were not used. 


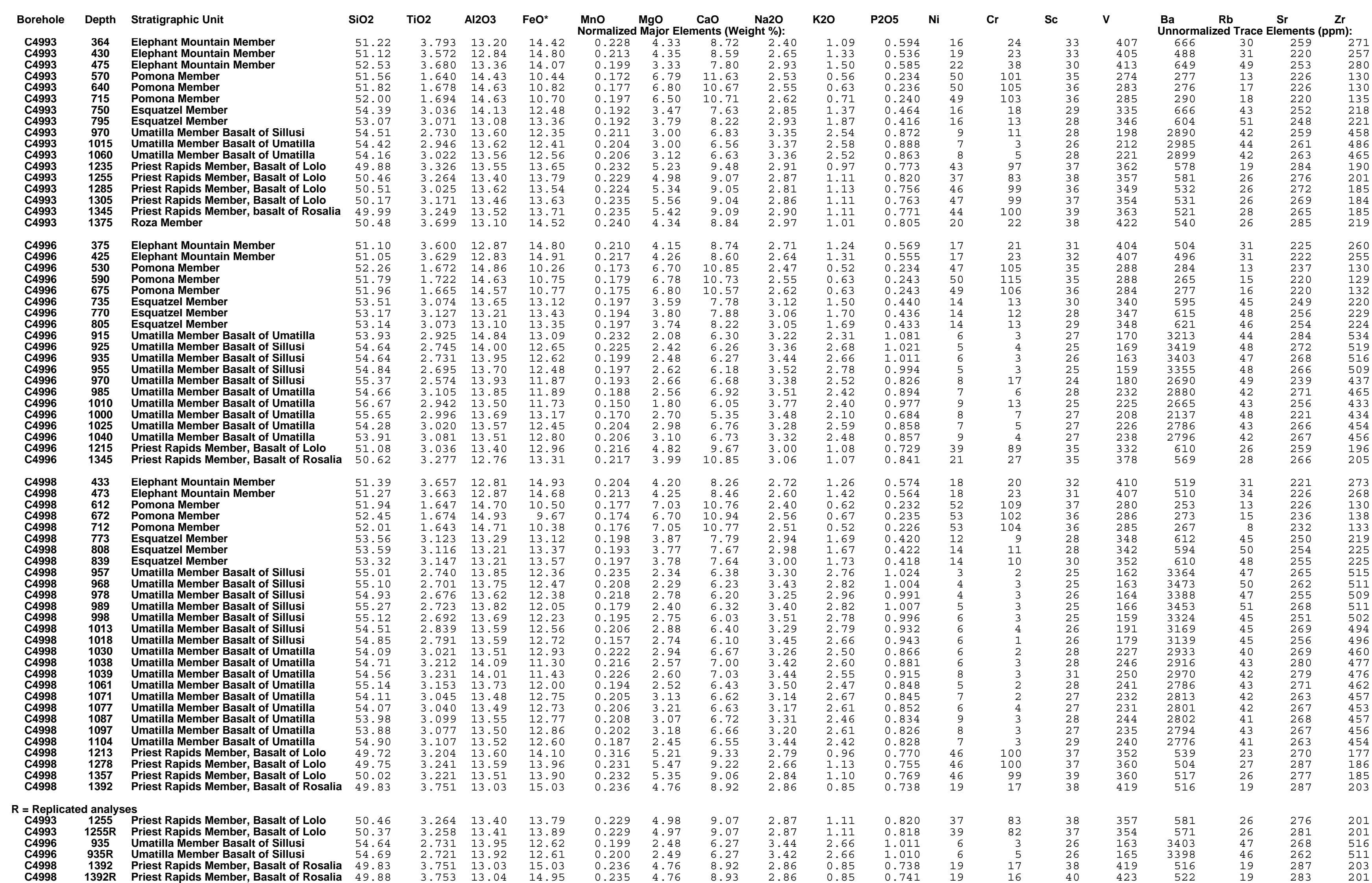


Appendix C

Secondary Features Observed in Core Hole C4998 


\section{Appendix C}

\section{Secondary Features Observed in Core Hole C4998}

\begin{tabular}{|c|c|c|c|c|c|}
\hline \multicolumn{6}{|c|}{ Prominent Secondary Features in Core Hole C4998 } \\
\hline Depth (ft bgs) & Feature & $\begin{array}{c}\text { Fracture Angle } \\
\text { (approx degrees from } \\
\text { horizontal) } \\
\end{array}$ & Secondary Minerals & $\begin{array}{c}\text { Relative } \\
\text { Displacement } \\
\text { Indicated }^{(a)} \\
\end{array}$ & Comments \\
\hline $426-427$ & "mullion" & 75 & $\begin{array}{l}\text { Clay/“white mineral” } \\
\text { (prob. Zeolite) }\end{array}$ & ND & \\
\hline 453 & Healed fracture & ND & Pyrite & None & Broken during extraction \\
\hline $473.4-474.4$ & Healed fracture & $\sim 45$ & Pyrite & None & Broken during extraction \\
\hline 492 & $\begin{array}{l}\text { Thin micro-breccia zones } \\
\text { and parallel clay-filled } \\
\text { fractures }\end{array}$ & ND & Zeolite/opal & ND & $\begin{array}{l}\text { In chill zone- probably } \\
\text { penecontemporaneous }\end{array}$ \\
\hline 518 & Fracture fill & $\sim 45$ & Clay & ND & XRD-clay \\
\hline 519 & $\begin{array}{l}\text { Replacements roughly } \\
\text { concordant with bedding }\end{array}$ & $0-10$ & $\begin{array}{l}\text { White mineral } \\
\text { probably zeolite }\end{array}$ & ND & \\
\hline $554-556$ & Breccia in basalt & NA & ND & ND & $\begin{array}{l}\text { Could be flow-top breccia and/or } \\
\text { tectonic }\end{array}$ \\
\hline $556-561$ & $\begin{array}{l}\text { Wide, numerous fractures } \\
\text { with slickensides }\end{array}$ & $\begin{array}{l}\text { Three groups: } 30-45 \text {, } \\
65-75 \text { and } 80-90\end{array}$ & Clay & Normal & $\begin{array}{l}\text { Probable fault zone-- } 75^{\circ} \text { fracture offset } \\
\text { by } 45^{\circ} \text { fracture with slickensides } \\
\text { indicating normal displacement }\end{array}$ \\
\hline 559.5 & Black fracture fill minerals & 75 & Clay & ND & XRD-clay, (pyroxene) \\
\hline $561.2-561.5$ & Chalcedony fracture fill & ND & Chalcedony & ND & $\begin{array}{l}\text { Three events indicated by brecciation, } \\
\text { truncation, re-cementation }\end{array}$ \\
\hline 563.7 & $\begin{array}{l}\text { High-angle fractures with } \\
\text { breccia }\end{array}$ & $45-60$ & Light-brown clay/opal & ND & \\
\hline 591.3 & Fractures & $45-60$ & Yellow-tan clay & ND & \\
\hline $599-602.5$ & Fractures & various & ND & ND & Anastomosing fractures \\
\hline $620.5-621$ & Slickensides on fractures & $\sim 75$ & ND & ND & \\
\hline $622-623$ & Fractures & various & ND & ND & Anastomosing fractures-possible offsets \\
\hline 623.5 & Pyrite in fracture & ND & Pyrite & ND & \\
\hline
\end{tabular}




\begin{tabular}{|c|c|c|c|c|c|}
\hline \multicolumn{6}{|c|}{ Prominent Secondary Features in Core Hole C4998 } \\
\hline Depth (ft bgs) & $\begin{array}{c}\text { Feature } \\
\end{array}$ & $\begin{array}{c}\text { Fracture Angle } \\
\text { (approx degrees from } \\
\text { horizontal) } \\
\end{array}$ & Secondary Minerals & $\begin{array}{c}\text { Relative } \\
\text { Displacement } \\
\text { Indicated }^{(\mathrm{a})} \\
\end{array}$ & Comments \\
\hline 631.5 & Fractures with slickensides & $80-90$ & Clay (black) & $\mathrm{ND}$ & $\begin{array}{l}\text { XRD-Clay (plagioclase, pyroxene) } \\
\text { "Intense fracturing" }\end{array}$ \\
\hline 634 & Fracture with slickensides & $\sim 60$ & ND & ND & Fracture fill $\sim 3 \mathrm{~mm}$ thick \\
\hline 642 & Fractures & $\sim 30$ & Clay, green, yellow & ND & XRD-clay \\
\hline 653.3 & Fracture with slickensides & $\sim 60$ & Clay & ND & XRD-clay \\
\hline 657.5 & Fracture with slickensides & $45-60$ & ND & ND & \\
\hline 663 & Fracture with slickensides & $\sim 75$ & ND & ND & \\
\hline $667.5-668$ & Fracture with slickensides & $\sim 75-80$ & ND & LL & Slickensides nearly horizontal \\
\hline $670.3-671.5$ & Fractures & $45-60$ & ND & ND & Alteration halo parallel to fractures \\
\hline 673 & Fracture with slickensides & $\sim 70$ & Clay, black, green & RL & $\begin{array}{l}\text { XRD-(green) Clay (pyroxene) XRD- } \\
\text { (black) Plagioclase, clay (pyroxene) fract } \\
\text { width }=\sim 0.75 \mathrm{~cm}\end{array}$ \\
\hline 693.5 & Fracture with slickensides & $50-60$ & Clay & ND & Fracture fill $\sim 0.5 \mathrm{~cm}$ thick \\
\hline $696-697$ & Fracture with slickensides & 90 & ND & LL/Reverse & \\
\hline 704.88 & Fracture with slickensides & 30 & $\mathrm{MnO}_{2} /$ clay & $\mathrm{RL}$ & \\
\hline $707-708.5$ & Fracture & $\sim 90$ & Clay & RL & Thick fracture with basalt clasts breccia \\
\hline $714.2-714.6$ & Fracture with slickensides & 60 & Clay & RL/Normal & $\begin{array}{l}\text { XRD-clay(plagioclase); fracture is } \\
3 \mathrm{~mm} \text { wide }\end{array}$ \\
\hline $719-722$ & Fracture with slickensides & $70-90$ & Clay & RL & \\
\hline 732.2 & Fracture with slickensides & $70-90$ & Dk green clay & LL & \\
\hline $791-793$ & Fracture with slickensides & $70-90$ & Blk vitreous clay & ND & \\
\hline $805-809$ & Fractures & ND & Pyrite & ND & \\
\hline 963.4 & Fractures & ND & Pyrite & ND & \\
\hline $968.4-971$ & Fractures & $0-60$ & Clay, zeolite & ND & \\
\hline $973-983$ & Fractures & ND & Clay & ND & Haloes $1-2 \mathrm{~cm}$ wide around fractures \\
\hline $1016.4-1018$ & Fractures & ND & ND & ND & Alteration halo parallel to fractures \\
\hline 1020.2 & Pyrite in scoria & 90 & Pyrite & ND & \\
\hline $1020.2-1024$ & Oxidation zone & ND & ND & ND & Scoria \\
\hline 1036 & Fractures with slickensides & ND & ND & ND & Vesicular basalt \\
\hline 1059.4 & Fractures with slickensides & ND & ND & Reverse & \\
\hline
\end{tabular}




\begin{tabular}{|c|c|c|c|c|c|}
\hline \multicolumn{6}{|c|}{ 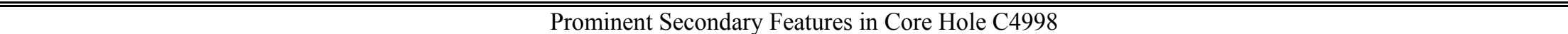 } \\
\hline Depth (ft bgs) & Feature & $\begin{array}{c}\text { Fracture Angle } \\
\text { (approx degrees from } \\
\text { horizontal) }\end{array}$ & Secondary Minerals & $\begin{array}{c}\text { Relative } \\
\text { Displacement } \\
\text { Indicated }^{(\mathrm{a})}\end{array}$ & Comments \\
\hline 1060.6 & Fracture offset & $30-75$ & Clay & ND & $\begin{array}{l}\text { Healed fractures--low angle fracture } \\
\text { offsets high-angle fracture }\end{array}$ \\
\hline 1090.3 & Vugs & ND & Clay, zeolite & ND & XRD-zeolite, clay \\
\hline 1264.7 & Fracture offset & $0-75$ & ND & ND & $\begin{array}{l}\text { High-angle fracture truncated by low- } \\
\text { angle fracture }\end{array}$ \\
\hline 1301 & Fracture with slickensides & 20 & ND & RL/Reverse & \\
\hline $1310-1311$ & Fractures & $65-80$ & Clay & ND & $0.5-\mathrm{cm}$ thick dark green fracture fill \\
\hline 1321.5 & Fracture with slickensides & 75 & ND & LL/Normal & \\
\hline 1351 & Fracture with slickensides & ND & ND & Normal & \\
\hline 1358.7 & Fracture with breccia & ND & Clay & ND & XRD-clay \\
\hline $1364.5-1365.4$ & Fracture with slickensides & $5-75$ & ND & Reverse & \\
\hline 1377.8 & Fracture with slickensides & ND & ND & RL & \\
\hline \multicolumn{6}{|c|}{$\begin{array}{l}\text { (a) LL= Left Lateral; RL=Right Lateral. } \\
\text { NA = Not Applicable. } \\
\text { ND = Not Determined. }\end{array}$} \\
\hline
\end{tabular}


Appendix D

\section{Hydrogeology of the Waste Treatment Plant Site}




\section{Appendix D}

\section{Hydrogeology of the Waste Treatment Plant Site}

This appendix briefly compares historical data and data collected by Fluor Hanford, Inc., during the WTP seismic borehole drilling project. The information presented below includes water table elevations from the four entry boreholes (C4998, C4996, C4997, and C4993) and nine groundwater contaminant samples (water and soil) collected from the entry portion of borehole C4997. Historical data presented in this section were compiled primarily from previous groundwater monitoring reports (e.g., Hartman et al. 2006).

\section{D.1 Waste Treatment Plant Site Water Table}

The major hydrogeologic units beneath the WTP site include the Hanford formation, the Ringold Formation, and the Columbia River Basalt Group (Figure D.1). The uppermost aquifer (i.e., water table aquifer) present below the WTP site is unconfined and is composed of unconsolidated to semiconsolidated sediment of the Hanford and Ringold formations, which were deposited on top of the basalt bedrock. Confined aquifers occur within the underlying basalt and associated sedimentary interbeds. All water table elevations measured and reported are from the uppermost unconfined aquifer below the WTP site. The water table lies between 270 and $280 \mathrm{ft}$ below the surface at an elevation of $\sim 400 \mathrm{ft}$ above mean sea level (Figure D.1). The unconfined aquifer ranges from 80 to $100 \mathrm{ft}$ thick and spans the entire Ringold Formation Unit A and the lower portion of the Cold Creek unit deposits above the Columbia River Basalt Group.

The regional groundwater flow direction in the unconfined aquifer generally flows from west to east across the Hanford Site to discharge areas along the Columbia River. This general west-to-east flow pattern was interrupted locally during the Hanford Site operating years by the groundwater mounds associated with the 200 Area wastewater discharges. Since effluent disposal ended in the 1990s, groundwater flow is returning to pre-Hanford conditions. Eventually, much of the suprabasalt sediment (Hanford and Ringold) will be dry because of falling water levels. Currently, groundwater is estimated to flow south to southwest beneath the WTP site (Figure D.2). The groundwater monitoring project for the 1992 fiscal year recorded the highest observed water table levels (Table D.1) for the WTP site, which lies within the boundaries of the former Grout Treatment Facility (DOE-RL 1992). Groundwater levels have declined roughly 2 to $3 \mathrm{ft}$ since 1992 monitoring (Table D.2). The water table elevation map for 2006 (Figure D.2) reflects the remnants of the water table mound to the immediate north of the WTP.

The water table beneath the 200 East Area is currently relatively flat in comparison to other areas on the Hanford Site because of the presence of the highly permeable sediment of the Hanford formation at the water table. Because the hydraulic gradient is nearly flat across the 200 East Area, small inaccuracies in water elevations are important when estimating flow direction and rate. For detailed water table elevation maps, refer to Hartman et al. (2006). 


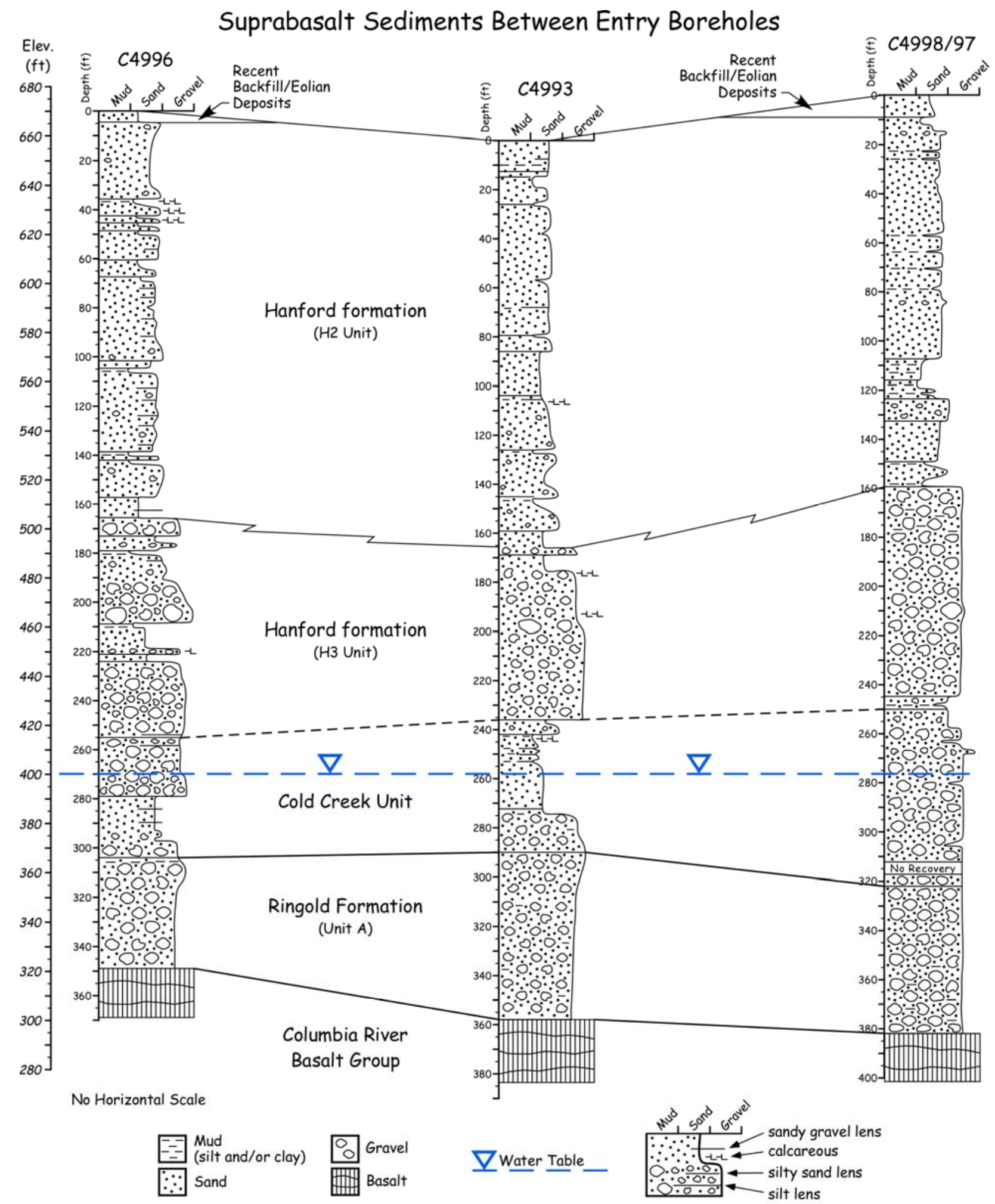

2007/DCL/WTPSB/001 (04/18)

Figure D.1. General Correlation of Strata Between Waste Treatment Plant Entry Holes 


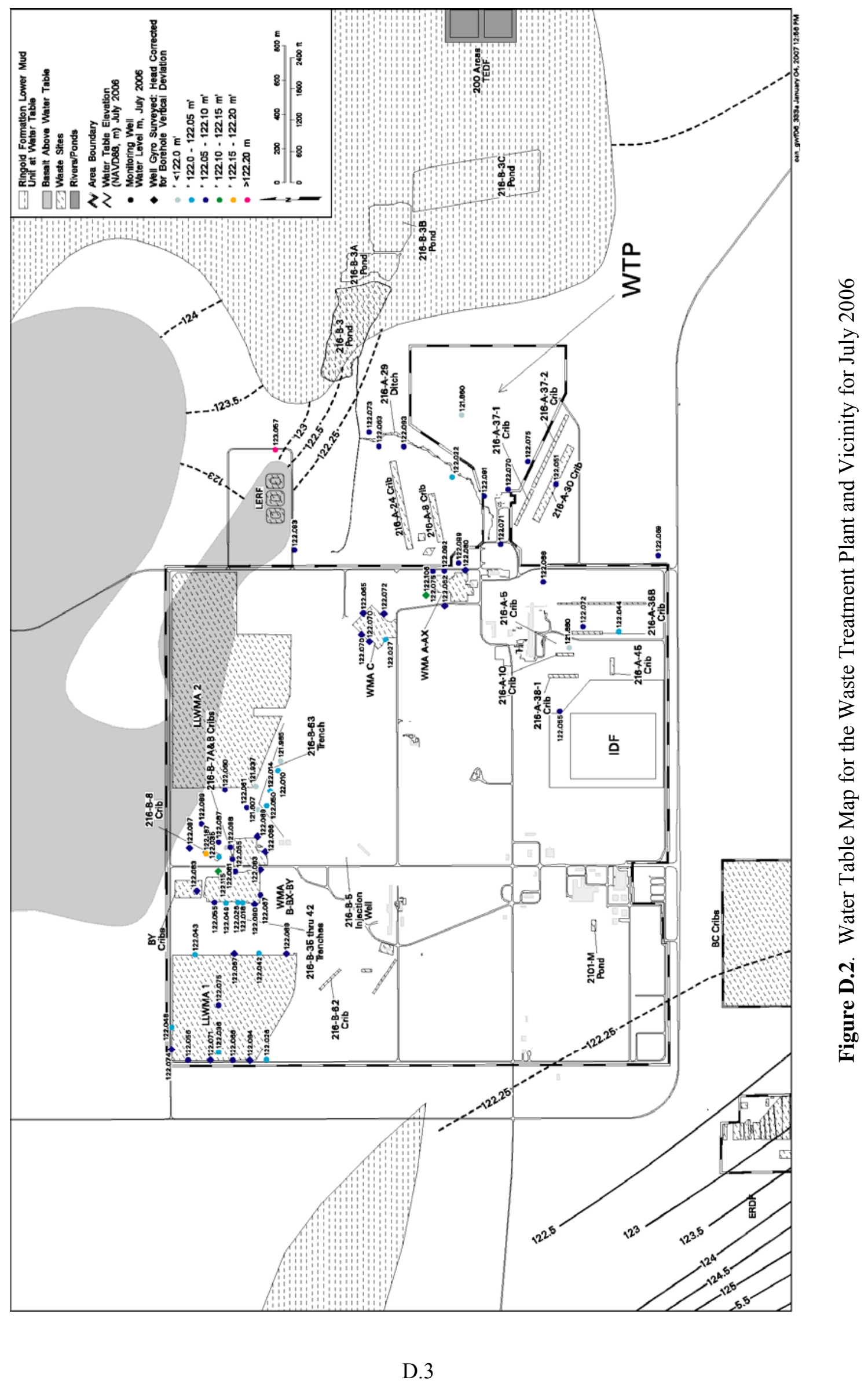


Table D.1. Water Table Levels, June 1992

\begin{tabular}{|c|c|c|c|}
\hline Borehole ID & Borehole Location & Aquifer & Water Level (ft - sea level) \\
\hline E25-28 & GTF Up gradient & Deep Unconfined & 402.26 \\
\hline E25-32P/Q & GTF Up gradient & Top of Unconfined & 402.63 \\
\hline E25-25 & GTF Up gradient & Upper Unconfined & 403.35 \\
\hline E25-37 & GTF Down gradient & Top of Unconfined & 402.92 \\
\hline E25-31 & GTF Down gradient & Top of Unconfined & 402.83 \\
\hline E25-29P/Q & GTF Down gradient & Top of Unconfined & 402.74 \\
\hline E25-33 & GTF Down gradient & Top of Unconfined & 402.90 \\
\hline E25-38 & GTF Down gradient & Top of Unconfined & 402.85 \\
\hline E25-44 & GTF Down gradient & Top of Unconfined & 402.99 \\
\hline \multicolumn{4}{|c|}{$\begin{array}{l}\text { Notes: } \\
\mathrm{ft} \text { - sea level = Feet above mean sea level. } \\
\text { GTF = Grout Treatment Facility. } \\
\text { Source: DOE-RL (1992). }\end{array}$} \\
\hline
\end{tabular}

Table D.2. Water Table Levels, July 2005

\begin{tabular}{|c|c|c|c|}
\hline Borehole ID & Borehole Location & Water Level (m - sea level) & Water Level (ft - sea level) \\
\hline E25-32Q & 200 East Area & 121.94 & 400.06 \\
\hline E25-31 & 200 East Area & 122.13 & 400.70 \\
\hline E25-44 & 200 East Area & 122.13 & 400.70 \\
\hline \multicolumn{4}{|c|}{$\begin{array}{l}\text { Notes: } \\
\mathrm{m} \text { - sea level = Meters above mean sea level. } \\
\mathrm{ft} \text { - sea level = Feet above mean sea level. } \\
\text { Source: Hartman et al. (2006). }\end{array}$} \\
\hline
\end{tabular}

Estimated groundwater flow rates in the vicinity of the WTP, based on hydraulic conductivities from slug tests (Last et al. 1989; Spane et al. 2003), ranged from 0.005 to $0.18 \mathrm{~m} /$ day, assuming a hydraulic gradient of 0.00002 (Hartman et al. 2006). The average water table decline beneath the 200 East Area was $10 \mathrm{~cm}$ during FY 2005, based on water-elevation data from wells 299-E33-32, 299-E33-32, 299-E33-33, 299-E33-334, 299-E33-38, 299-E33-39, 299-E33-41, 299-E33-42, 299-E33-43, and 299-E33-44. The water table is no longer subject to wide fluctuations evident during operational years and is resuming a steadier rate of decline. Water table levels of the four boreholes (C4998, C4996, C4997, and C4993) at the WTP site were measured after completion of each entry hole. Water levels measured at the time of completion are listed in Table D.3.

Table D.3. Water Table Levels, August 2006

\begin{tabular}{|c|c|c|c|}
\hline Borehole ID & Borehole Location & Water Level (ft bgs) & Water Level (ft - sea level) \\
\hline C4993 & WTP Site & 258.2 & 400 \\
\hline C4996 & WTP Site & 270 & 400.1 \\
\hline C4997* & WTP Site & 277.5 & 399.4 \\
\hline C4998 & WTP Site & 278 & 398.9 \\
\hline \multicolumn{4}{|c|}{$\begin{array}{l}\text { Notes: } \\
\mathrm{ft} \text { bgs }=\text { Feet below ground surface. } \\
\mathrm{ft}-\text { sea level = Feet above mean sea level. } \\
*=\text { Water and soil samples are discussed in Section D.2. }\end{array}$} \\
\hline
\end{tabular}




\section{D.2 Groundwater Sampling and Analysis}

Historically, three groundwater contaminants — tritium H3, iodine-129, and technetium-99 - have been detected in the vicinity of the WTP (Hartman et al. 2006). Contaminant indicator parameters tested for borehole C4997 in 2006 are listed in Table D.4.

Table D.4. Contaminant Indicator Parameters Tested for Entry Borehole C4997

\begin{tabular}{|c|c|}
\hline $\begin{array}{l}- \\
- \\
- \\
- \\
- \\
- \\
- \\
\end{array}$ & 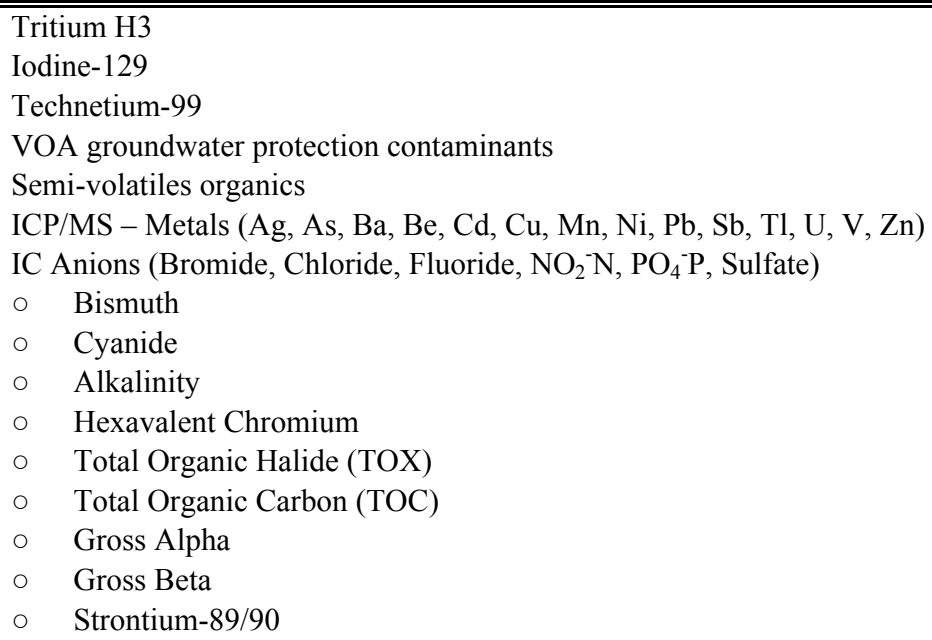 \\
\hline
\end{tabular}

Contaminant concentrations were compared with state or federally enforceable drinking water standards (Table D.5) to confirm the nonhazardous conditions at the WTP site. Although Hanford Site groundwater is not generally used for drinking, these levels provide perspective on contaminant concentrations. None of the soil or water samples analyzed and discussed here is comparable or above the drinking water standards.

Table D.5. Drinking Water Standards

\begin{tabular}{||l|c|c||}
\hline \multicolumn{1}{|c|}{ Constituent } & Drinking Water Standard & Agency \\
\hline \hline Tritium $\mathrm{H} 3$ & $20,000 \mathrm{pCi} / \mathrm{L}$ & EPA, DOE \\
\hline Iodine-129 & $1 \mathrm{pCi} / \mathrm{L}$ & EPA \\
\hline Technetium-99 & $900 \mathrm{pCi} / \mathrm{L}$ & EPA \\
\hline Notes: & \\
pCi/L $=$ Picocuries per liter. \\
EPA $=$ U.S. Environmental Protection Agency. \\
DOE $=$ U.S. Department of Energy. \\
\hline
\end{tabular}

\section{D.3 Soil Sampling and Analysis}

During August 2006, seven soil samples were collected from borehole C4997 during the entry drilling phase. These samples (B1K9B8, B1K9B9, B1K9C0, and B1K9C1, B1K9B4, and B1KB74) were collected and analyzed for Fluor Hanford, Inc. Analytical data for soil samples are presented at the end of this appendix. Results of these analyses are discussed below. Samples were collected from August 9 
through 17,2006 , and analyzed before mud rotary drilling commenced. Groundwater contaminant indicator parameters were chosen and tested within entry borehole C4997 to confirm the nonhazardous conditions beneath the WTP site.

A summary of results of soil analyses is provided in Table D.6. The analyses completed on the soil samples B1K9B8 and B1K9C0 showed results below the detection limit criteria for the particular analysis completed. Results of soil sample B1K9C1 were either below detection limit or below maximum contaminant levels for all constituents tested. Of the results above the detection limit, none for sample B1K9C1 exceeded the maximum allowable concentration for contaminant levels.

A summary of soil samples B1K9D3, B1KC04, and B1KC08 analyzed by Eberline Services for Fluor Hanford is provided in Table D.7. The analysis completed on the three soil samples showed results below the detection limit criteria for tritium H3, iodine-129, and technetium-99.

Table D.6. Soil Sampling Summary for Entry Borehole C4997, Fluor Hanford, Inc.

\begin{tabular}{||c|c|c|c|c||}
\hline $\begin{array}{c}\text { Date } \\
(2006)\end{array}$ & $\begin{array}{c}\text { Sample } \\
\text { Type }\end{array}$ & \multicolumn{1}{|c||}{ Analysis Completed on Soil Sample } & $\begin{array}{c}\text { HEIS } \\
\text { Numbers }\end{array}$ & $\begin{array}{c}\text { Results } \\
\text { Summary }\end{array}$ \\
\hline \hline 9-Aug & Soil (Solid) & VOA - low level & B1K9B8 & U \\
\hline 9-Aug & Soil (Solid) & VOA- high level (not analyzed) & B1K9B9 & N/A \\
\hline 9-Aug & Soil (Solid) & VOA - TCL & B1K9C0 & U \\
\hline 9-Aug & Soil (Solid) & $\begin{array}{l}\text { Anions by Ion Chromatography, Bismuth, Cyanide, ICP/MS } \\
- \text { Metals, Semi-Volatiles (Organic), VOA Groundwater } \\
\text { Protection (Organic), Radiochemistry (Gamma Energy, } \\
\text { Gross Alpha, Gross Beta, Strontium 89/90) }\end{array}$ & B1K9C1 & U \\
\hline $\begin{array}{l}\text { Notes: U = Not detected. } \\
\text { Below DWS = Below drinking water standards. } \\
\text { N/A = Not analyzed. } \\
\text { TOX = Total organic halide. } \\
\text { TOC = Total organic carbon. }\end{array}$ & & \\
\hline
\end{tabular}

Table D.7. Summary of Soil Radionuclide Analyses for Entry Borehole C4997

\begin{tabular}{||c|c|c|c|c|c|c||}
\hline $\begin{array}{c}\text { Date } \\
(2006)\end{array}$ & $\begin{array}{c}\text { Sample } \\
\text { Type }\end{array}$ & $\begin{array}{c}\text { Sampling Methods } \\
\text { in Solids }\end{array}$ & $\begin{array}{c}\text { HEIS } \\
\text { Numbers }\end{array}$ & $\begin{array}{c}\text { Tritium H3 } \\
\text { Result (pCi/g) }\end{array}$ & $\begin{array}{c}\text { Iodine-129 } \\
\text { Result (pCi/g) }\end{array}$ & $\begin{array}{c}\text { Technetium-99 } \\
\text { Result (pCi/g) }\end{array}$ \\
\hline \hline 15-Aug & Soil (Solid) & $\begin{array}{c}\text { Tritium H3 Iodine- } \\
129 \text { Technetium-99 }\end{array}$ & B1K9D3 & $\mathrm{U}(-0.336)$ & $\mathrm{U}(0.119)$ & $\mathrm{U}(-0.137)$ \\
\hline 16-Aug & Soil (Solid) & $\begin{array}{c}\text { Tritium H3 Iodine- } \\
129 \text { Technetium-99 }\end{array}$ & B1KC04 & $\mathrm{U}(0.823)$ & $\mathrm{U}(-0.305)$ & $\mathrm{U}(0.064)$ \\
\hline 16-Aug & Soil (Solid) & $\begin{array}{c}\text { Tritium H3 Iodine- } \\
129 \text { Technetium-99 }\end{array}$ & B1KC08 & $\mathrm{U}(-0.197)$ & $\mathrm{U}(-0.314)$ & $\mathrm{U}(-0.169)$ \\
\hline 16-Aug & Soil (Solid) & $\begin{array}{l}\text { Tritium H3 Iodine- } \\
129 \text { Technetium-99 }\end{array}$ & $\begin{array}{c}\text { Duplicate } \\
\text { (B1KC08) }\end{array}$ & $\mathrm{U}(0.970)$ & $\mathrm{U}(0.179)$ & $\mathrm{U}(-0.144)$ \\
\hline $\begin{array}{l}\text { Notes: U = Not detected. } \\
\text { pCi/g = Picocuries per gram. } \\
\text { HEIS= Hanford Environmental Information System. }\end{array}$ \\
\hline
\end{tabular}




\section{D.4 Conclusions}

Overall, contaminants in the groundwater samples from the $\mathrm{C} 4997$ borehole were either below detection limits or below drinking water standards. Similar results were obtained for vadose zone samples. For the three major contaminants of concern within the 200-PO-1 Operable Unit - tritium H3, iodine-129, and technetium-99-all concentrations were less than $1 \mathrm{pCi} / \mathrm{g}$. A summary of the two water samples (B1K9B4 and B1KB74) analyzed by Eberline Services for Fluor Hanford, Inc., is provided in Table D.8. The analysis completed on the two water samples showed results below the detection limit criteria for iodine-129.

Table D.8. Water Samples Summary for Entry Borehole C4997, Eberline Services

\begin{tabular}{||c|c|c|c|c|c||}
\hline $\begin{array}{c}\text { Date } \\
(2006)\end{array}$ & $\begin{array}{c}\text { Sample } \\
\text { Type }\end{array}$ & $\begin{array}{c}\text { Sampling Method in } \\
\text { Water }\end{array}$ & HEIS Numbers & $\begin{array}{c}\text { Depth Interval } \\
(\mathrm{ft} \text { bgs) }\end{array}$ & $\begin{array}{c}\text { Iodine-129 } \\
\text { Result (pCi/g) }\end{array}$ \\
\hline \hline 15-Aug & Water & Iodine-129 & B1K9B4 & $334.5-339.0$ & U (0.080) \\
\hline 17-Aug & Water & Iodine-129 & B1KB74 & $364.5-367.6$ & U (-0.308) \\
\hline 17-Aug & Water & Iodine-129 & Duplicate (B1KB74) & $364.5-367.6$ & U (-1.46) \\
\hline $\begin{array}{l}\text { Notes: U }=\text { Not detected. } \\
\text { ft bgs = Feet below ground surface. }\end{array}$
\end{tabular}

As for all other analysis done on C4997 samples, Table D.9 summarizes the concentrations and parameters used to screen for contaminants in groundwater and the vadose zone at the WTP site. For organizational purposes, only the three major contaminants (tritium H3, iodine-129, and technetium-99) and results above detection limit were listed. Based on the groundwater contaminant indicator parameters chosen and tested within the centrally located entry borehole (C4997), the nonhazardous conditions at the WTP site can be confirmed.

\section{D.5 References}

DOE-RL. 1992. Annual Report for RCRA Groundwater Monitoring Projects at Hanford Site Facilities for 1992. DOE/RL-93-09, Rev. 0, U.S. Department of Energy, Geosciences Group, Westinghouse Hanford Company, Environmental Division, Richland, Washington.

Hartman MJ, LF Morasch, and WD Webber (eds). 2006. Hanford Site Groundwater Monitoring for Fiscal Year 2005. PNNL-15670, Pacific Northwest National Laboratory, Richland, Washington.

Last GV, BN Bjornstad, MP Bergeron, DE Wallace, DR Newcomer, JA Schramke, MA Chamness, CS Cline, SP Airhart, and JS Wilbur. 1989. Hydrogeology of the 200 Areas Low-Level Burial Grounds An Interim Report. PNL-6820, Volumes 1 and 2, Pacific Northwest Laboratory, Richland, Washington.

Spane FA, DR Newcomer, and PR Thorne. 2003. Results of Detailed Hydrologic Characterization Tests - Fiscal Year 2002. PNNL-14186, Pacific Northwest National Laboratory, Richland, Washington. 
Table D.9. Analytical Summary for Contaminants in Groundwater and Vadose Zone for C4997

\begin{tabular}{|c|c|c|c|}
\hline Contaminant & Max Concentration & Units & Result Qualifier \\
\hline \multicolumn{4}{|c|}{ Known Groundwater Contaminants in 200 East Area } \\
\hline Tritium (Hydrogen-3) & 0.970 & $\mathrm{pCi} / \mathrm{g}$ & $\mathrm{U}$ \\
\hline Iodine-129 (Soil) & 0.179 & $\mathrm{pCi} / \mathrm{g}$ & $\mathrm{U}$ \\
\hline Iodine-129 (Water) & 0.080 & $\mathrm{pCi} / \mathrm{L}$ & $\mathrm{U}$ \\
\hline Technetium-99 & 0.064 & $\mathrm{pCi} / \mathrm{g}$ & $\mathrm{U}$ \\
\hline \multicolumn{4}{|l|}{ Metals } \\
\hline Manganese & 165 & $\mathrm{mg} / \mathrm{kg}$ & \\
\hline Nickel & 7.26 & $\mathrm{mg} / \mathrm{kg}$ & \\
\hline Barium & 52.4 & $\mathrm{mg} / \mathrm{kg}$ & $\mathrm{E}$ \\
\hline Beryllium & 0.142 & $\mathrm{mg} / \mathrm{kg}$ & \\
\hline Cadmium & 0.078 & $\mathrm{mg} / \mathrm{kg}$ & \\
\hline Chromium & 10.4 & $\mathrm{mg} / \mathrm{kg}$ & \\
\hline Copper & 11.8 & $\mathrm{mg} / \mathrm{kg}$ & \\
\hline Vanadium & 41.0 & $\mathrm{mg} / \mathrm{kg}$ & \\
\hline Zinc & 26.9 & $\mathrm{mg} / \mathrm{kg}$ & \\
\hline Lead & 1.99 & $\mathrm{mg} / \mathrm{kg}$ & \\
\hline Mercury & 0.448 & $\mathrm{mg} / \mathrm{kg}$ & \\
\hline Uranium & 0.298 & $\mathrm{mg} / \mathrm{kg}$ & \\
\hline Thallium & 0.0554 & $\mathrm{mg} / \mathrm{kg}$ & \\
\hline \multicolumn{4}{|l|}{ Semi - Volatiles - Organics } \\
\hline Bis (2-ethylhexyl) phthalate & 490 & $\mu \mathrm{g} / \mathrm{kg}$ & \\
\hline Di-n-butylphthalate & $1.60 \mathrm{e}+03$ & $\mu \mathrm{g} / \mathrm{kg}$ & \\
\hline \multicolumn{4}{|l|}{ Gross Alpha } \\
\hline Gross Alpha & 2.2 & $\mathrm{pCi} / \mathrm{g}$ & \\
\hline \multicolumn{4}{|c|}{$\begin{array}{l}\text { Notes: } \mathrm{U}=\text { Analyzed for but not detected above limiting criteria. } \\
*=\text { Above detection limit. } \\
\mathrm{E}=\text { Analyst estimate, has potentially larger errors. }\end{array}$} \\
\hline
\end{tabular}




\section{Distribution}

No. of

Copies

OFFSITE

C. J. Costantino

4 Rockingham Road

Spring Valley, NY 10977

J. A. McCloskey

U.S. Department of Energy

Headquarters, EM-23

19901 Germantown Road

Germantown, MD 20874

B. B. Redpath

Redpath Geophysics

P.O. Box 540

Murphys, CA 95247

K. H. Stokoe II

University of Texas at Austin

Department of Civil Engineering

College of Engineering

1 University Station C1700

Austin, TX 78712

6 U.S. Army Corps of Engineers

Seattle District

P.O. Box 3755

Seattle, WA 98124-3755
A. P. Dimbirs (4)
R. O. Garrison
R. E. Smith

C. F. Rust

Freestone Environmental Services, Inc.

1100 Jadwin Avenue, Suite 250

Richland, WA 99352
No. of

Copies

ONSITE

4 DOE Office of River Protection

W. Abdul H6-60

J. R. Eschenberg H6-60

T. R. Hoertkorn H6-60

L. F. Miller H6-60

2 Bechtel National, Inc.

L. T. Lamm

MS4-A2

M. R. Braccia

MS 5-K

EnergySolutions

M. G. Gardner

G1-62

2 Fluor Hanford, Inc.

S. H. Worley E6-35

C. S. Wright E6-35

Washington Closure Hanford, LLC

K. R. Fecht

H4-21

Washington State Department of Ecology

J. A. Caggiano

$\mathrm{H} 0-57$

14 Pacific Northwest National Laboratory

K6-75

B. N. Bjornstad

K6-81

T. M. Brouns (5)

K9-69

D. G. Horton

K6-75

D. C. Lanigan

K6-75

S. P. Reidel

K6-75

A. C. Rohay

K6-75

Information Release (3)

P8-55 